AL.2.2001-74

c.2 2

SOIL AND VEGETATION INVENTORY

OF WAGNER NATURAL AREA, ALBERTA 


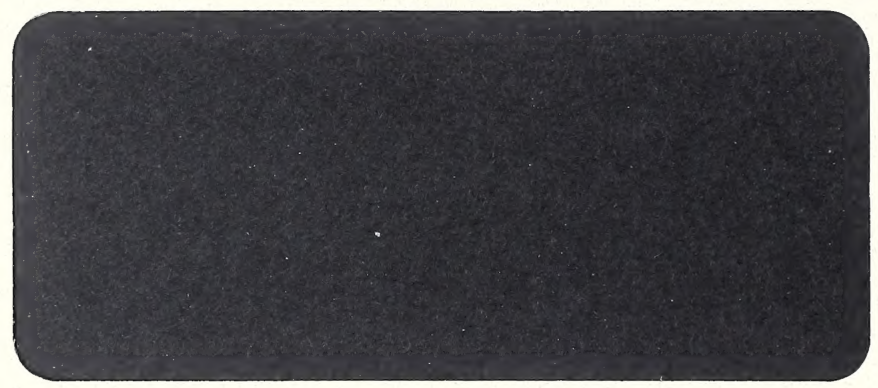




\title{
SOIL AND VEGETATION INVENTORY \\ OF WAGNER NATURAL AREA, ALBERTA
}

\author{
Prepared for: \\ Alberta Environment \\ Resource Data Division \\ Edmonton, Alberta
}

\begin{abstract}
Prepared by
K. Vujnovic ${ }^{1}$

L. Nikiforuk ${ }^{2}$

J. Bentz 1

P. Beaudette ${ }^{1}$
\end{abstract}

${ }^{1}$ Geowest Environmental Consultants Ltd.

Suite 203, Bedford Square

$4209-99^{\text {th }}$ Street

Edmonton, Alberta

T6E 5V7

\author{
${ }^{2}$ Soil-Info Ltd. \\ 199 Rhatigan Road East \\ Edmonton, Alberta \\ T6R 1N6
}

March, 2000 
$-4 \ldots$ 


\section{EXECUTIVE SUMMARY}

Wagner Natural Area is situated approximately $6.4 \mathrm{~km}$ west of the present city limits of Edmonton, Alberta, and encompasses approximately 160 ha of crown land. The Wagner Natural Area Management Plan (Wagner Natural Area Society and Alberta Environmental Protection (WNAS and AEP) 1999) stated that site has been "designated by policy as a Conservation Natural Area". Wagner Natural Area is also one of over 80 Ecological Monitoring and Assessment Network (EMAN) sites that have been established across Canada to conduct long-term ecological monitoring with the objective of understanding ecosystem change.

The cumulative effects of the present uses of the site for research, education and limited recreation, and the increasing demand for urbanization and recreation, may cause negative impacts on the site itself as well as conflicts among users of the Natural Area. WNAS and AEP (1999) provides guidelines for protecting natural features of the site while allowing restricted use for research, education and recreation. In support of management initiatives, Alberta Environment contracted Geowest Environmental Consultants Ltd. to update and standardize information on soils and vegetation for the Natural Area.

The following specific project objectives were identified:

- Complete a detailed soil survey and produce a soils map and legend at 1:5,000 scale of Wagner Natural Area;

- Complete a detailed vegetation inventory and produce a vegetation community type map and legend at 1:5,000 scale of Wagner Natural Area;

- Complete a plant community classification for Wagner Natural Area based on a field survey, previously collected data, and correlation with other work (vegetation classifications published in the relevant literature); 
Digitized by the Internet Archive in 2017 with funding from University of Alberta Libraries 
- Produce a report outlining the details of field and analytical methods, study results and a discussion of possible applications of the soil and vegetation inventories to biodiversity monitoring.

Field work was conducted during July 5-23/1999, from which data for 18 detailed and 73 reconnaissance plots were collected in compliance with the guidelines provided in the Ecological Land Survev Site Description Manual, Alberta Forest Service Range Survey Manual and the Canadian System of Soil Classification.

Soil mapping of Wagner Natural Area resulted in the identification of 17 soil units (46 soil and landscape polygons). The dominant soils of the area are carbonated Organics (various subgroups). Mineral soils are confined to a few developed upland areas (hay fields and the old cabin area). The mineral soils are dominantly Dark Gray Luvisols developed on medium textured glaciofluvial deposits. The majority of the area is level (slopes less than 1 percent).

Secondary carbonates were present in many of the mapped organic and mineral soils. The presence of carbonates in the soil profile is caused by precipitation from calcium carbonate enriched groundwater.

Aerial photo interpretation and related plot data, supported by two cluster analyses, resulted in the classification and mapping of eight native vegetation community types that were further subdivided into 20 subtypes based on differences in the dominant understory species. Within the study area, a black spruce-tamarack community type dominates forested areas, followed by the white spruce-black spruce, white spruce-balsam poplar, balsam poplar-aspen, Alaska birch-balsam poplar, and white spruce community types. Willow/sedge-bluejoint was the only shrubland community identified. The rich calcareous fen community type was also described. Miscellaneous cover types, such as agricultural fields, are also identified and mapped.

Certain relationships between vegetation communities and local environmental conditions were noted. Mineral soils in the agricultural fields occupy the dry end of the soil moisture gradient and are also the 

least minerotrophic of all soils found in the area. The soils from fen communities occupy the wettest end of the moisture gradient. They are also the most nutrient rich. Higher water tables and lower nutrient concentrations in the top $30 \mathrm{~cm}$ of the soil distinguish the soils supporting black sprucetamarack communities from those found in other community types. Soils found in association with the remaining vegetation community types in Wagner Natural Area are in the middle range of moisture and nutrient regimes. The reasons for the present distribution of deciduous, mixedwood, and white spruce community types can only be hypothesized. More detailed long-term studies on geomorphology, hydrology, soil micronutrient dynamics and disturbance history are needed to better understand ecosystem functions in Wagner Natural Area.

In addition to the soil and vegetation inventory, the establishment of 18 permanent monitoring plots in accordance with EMAN protocols was achieved in this study. It is hoped that the information on soils and present vegetation composition within the study area, in conjunction with the establishment of the monitoring plots, will provide an opportunity to assess and document vegetation community changes over time. 



\section{ACKNOWLEDGEMENTS}

We wish to thank Keith Ainsley, Joyce Gould, Elly Marshal, and John Rintoul (Alberta Environment), and Derek Johnson, Pat Clayton, and Alice Hendry (Wagner Natural Area Society) for assistance throughout the project. Many thanks go to Patsy Cotterill (Wagner Natural Area Society) for assistance with identifying voucher specimens of vascular plants, compilation of species list for vascular plants for Wagner Natural Area, and advice, encouragement and assistance throughout the project. Thanks also to Derek Johnson for providing list of non-vascular plants for Wagner Natural Area. We also thank Dr. Dale Vitt (University of Alberta) for identifying moss, liverwort and lichen voucher specimens.

Within Geowest, the following individuals are thanked for their involvement in digital map and database preparation: Della Clish, Lorrie Agnew, Terry Lang, Myron Karpiak, John Sisson, and James Squarok.

We are also grateful to Dragomir Vujnovic for his assistance in the report preparation. 



\section{TABLE OF CONTENTS}

EXECUTIVE SUMMARY

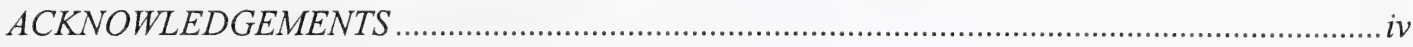

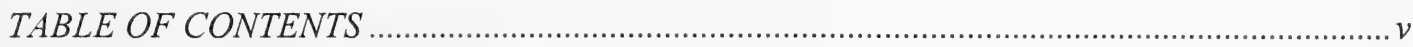

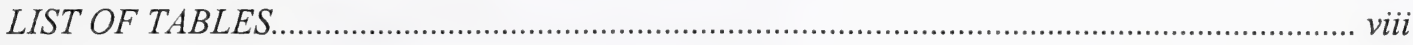

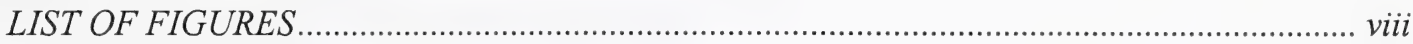

LIST OF APPENDICES AND MAPS ......................................................................... ix

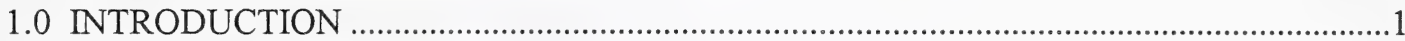

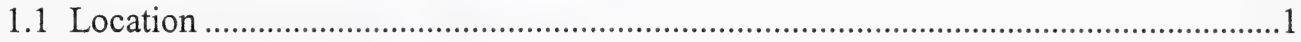

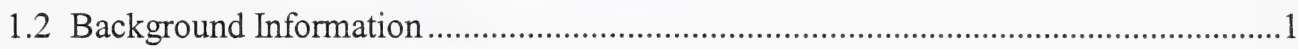

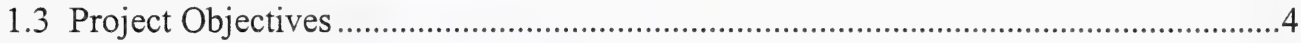

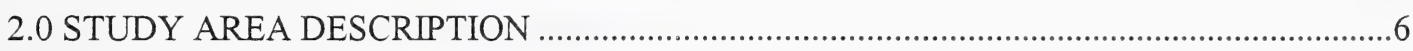

2.1 Climate

2.2 Bedrock and Surficial Geology .................................................................................

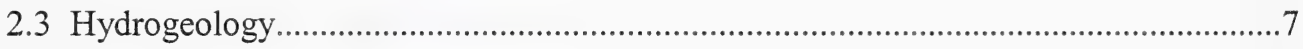

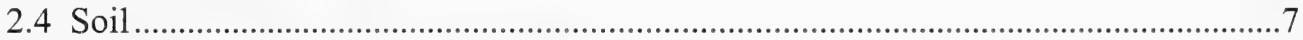

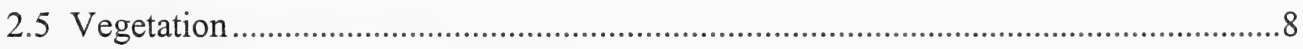

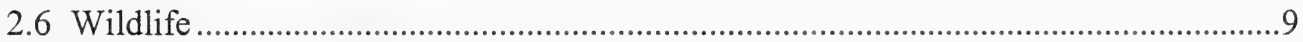

2.7 Natural and Anthropogenic Disturbances .................................................................

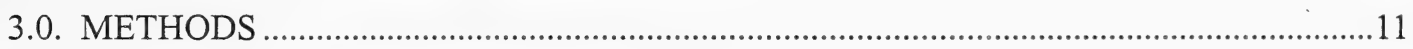

3.1 Collection of Background Information ....................................................................11

3.2 Preliminary Air-Photo Interpretation .......................................................................11

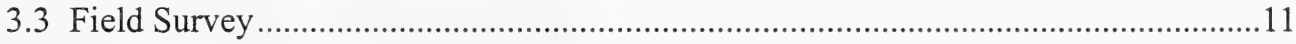

3.3.1 Plot Selection and Location .........................................................................11

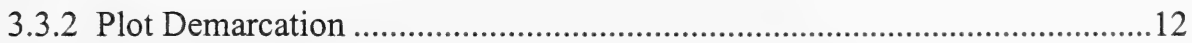

3.3.3 Soil Data Collection and Sampling...............................................................13

3.3.4 Vegetation Data Collection and Sampling......................................................15

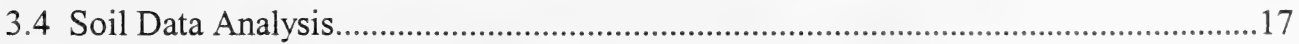



3.5 Vegetation Data Analysis and Classification................................................................17

3.6 Soil Mapping and Database Development.................................................................19

3.7 Vegetation Mapping and Database Development......................................................20

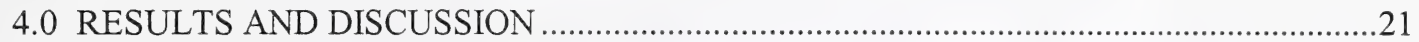

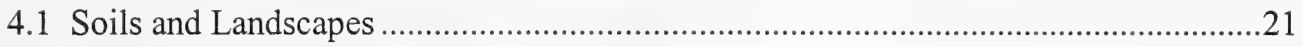

4.1.1 Brightbank (BRK) Soil Units.................................................................23

4.1.1.1 BRK1 Soil Units ........................................................................23

4.1.2 Carvel (CVL) Soil Units ........................................................................24

4.1.2.1 CVL1 Soil Units .........................................................................24

4.1.2.2 CVL2 Soil Units .......................................................................24

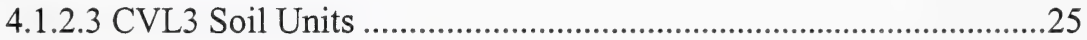

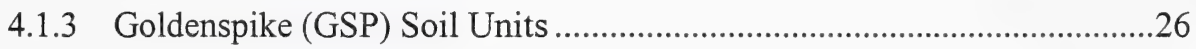

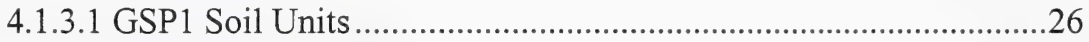

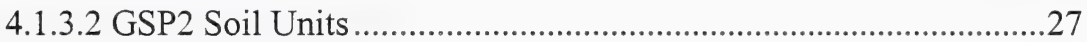

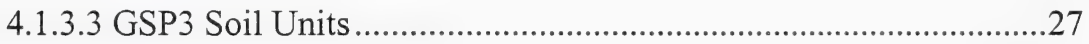

4.1.3.4 GSP4 Soil Units ........................................................................28

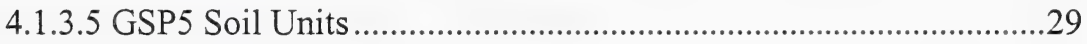

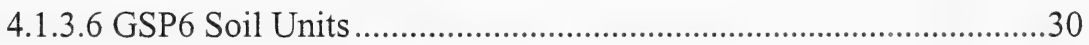

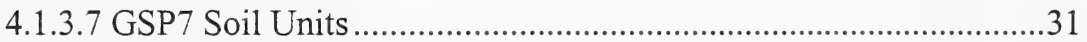

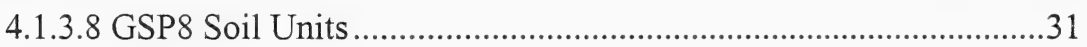

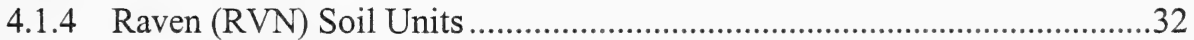

4.1.4.1 RVN1 Soil Units...........................................................................32

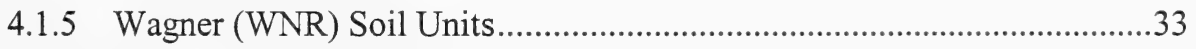

4.1.5.1 WNR1 Soil Units ...........................................................................33

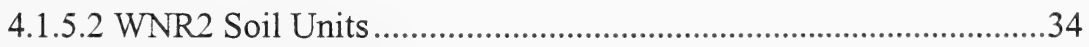

4.1.6 Water (ZWA) Units ..................................................................................35

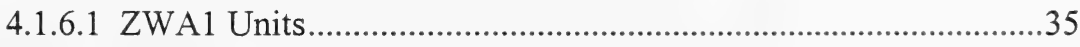

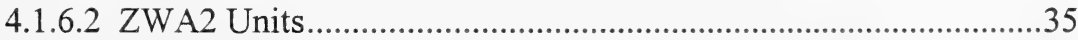

4.2 Native Vegetation Communities and Miscellaneous Cover Type ................................35

4.2.1 Floristic and Ecological Characteristics of Native 

Vegetation Communities 37

4.2.1.1 Deciduous Communities............................................................... 37

4.2.1.2 Mixedwood Communities ............................................................40

4.2.1.3 Coniferous Communities ..............................................................43

4.2.1.4 Shrubland Communities ...............................................................45

4.2.1.5 Wetland Communities ................................................................46

4.2.2 Miscellaneous Cover Types .........................................................................48

4.2.3 Cluster Analysis of Vegetation Communities...................................................49

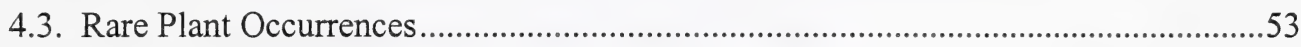

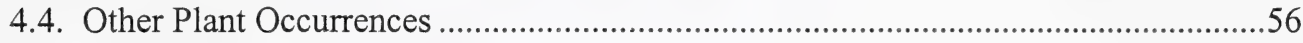

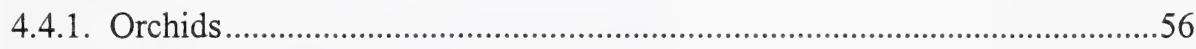

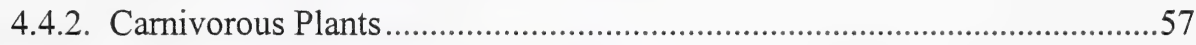

4.5. Correlation Between Native Vegetation Communities

Described in Wagner Natural Area and

Communities Listed in Relevant Literature

4.6. Relationships Between Native Vegetation Communities in the Wagner

Natural Area and Local Environmental Conditions.....................................................60

4.7. Application of Inventory to EMAN Biodiversity Monitoring ......................................62

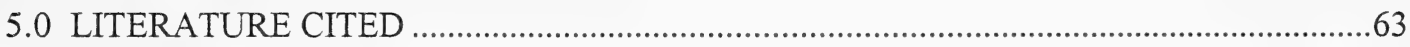





\section{LIST OF TABLES}

Table 1. Soils legend

Table 2. Native vegetation community types, subtypes, and miscellaneous cover types mapped within Wagner Natural Area

Table 3. TWINSPAN classification of 90 plots and 256 vascular and non-vascular plant species in Wagner Natural Area

Table 4. Correlations between vegetation community subtypes described in Wagner Natural Area 2000 study with similar community types listed in Alberta ecosite references and other relevant literature

\section{LIST OF FIGURES}

Figure 1. Location of Wagner Natural Area

Figure 2. Eight plot groups $(\mathbf{A}-\mathbf{H})$ derived by the Unweighted Arithmetical Average Clustering (UPGMA) of 90 plots and 256 vascular and non-vascular plant species in Wagner Natural Area. 



\section{LIST OF APPENDICES AND MAPS}

APPENDIX 1. GPS Positions of Detailed Plots in Wagner Natural Area

APPENDIX 2. Color Photographs of Representative Features

APPENDIX 3. Soil Sample List

APPENDIX 4. Soil Polygon Attribute Data

APPENDIX 5. Vegetation Polygon Attribute Data

APPENDIX 6. Vascular and Non-vascular Plant Species Recorded During Wagner Natural Area Study

APPENDIX 7. Wagner Natural Area: Vascular Plant List

APPENDIX 8. Bryophytes, Lichens and Fungi of Wagner Natural Area

APPENDIX 9. Alberta Natural Heritage Information Centre Definitions

MAP 1. Vegetation Communities of Wagner Natural Area

MAP 2 Soils of Wagner Natural Area 



\subsection{INTRODUCTION}

\subsection{Location}

Wagner Natural Area is a small, protected area of about 144 ha of crown land located approximately $6.4 \mathrm{~km}$ west of the present city limits of Edmonton, Alberta. It includes parts of Sections 7 and 8 , within Township 53, Range 26, West of the $4^{\text {th }}$ Meridian (legal description NE7, NW8, SW8-53-26W4M) (Figure 1). Portions of Section 8 were added to Wagner Natural Area in 1991 subsequent to the development of an interchange between Highway 16 and secondary Highway 794 (a connection road south of Highway 16) just east of Wagner Natural Area (P. Clayton, personal communication).

\subsection{Background Information}

Wagner Natural Area is part of a rich calcareous peatland, popularly known as "Wagner bog" east of Spruce Grove. The site received its legal Natural Area status in 1987, and it has been designated by provincial government policy as a Conservation Natural Area. Wagner Natural Area is also one of over 80 Ecological Monitoring and Assessment Network (EMAN) sites that have been established across the country to conduct long-term ecological monitoring with the objective of understanding ecosystem change (Roberts-Pichette and Gillespie 1999).

The most ecologically significant features of Wagner Natural Area are the rich* calcareous fen and marl pond habitats occupying approximately $8 \%$ of the site, and the presence of a number of rare and/or significant species, including 16 of the 26 species of orchid that occur in Alberta (McIsaac and Macdonald n.d., Moss 1983). Fourteen plant species occurring within Wagner Natural Area are presently included in the Alberta Natural Heritage Information Centre (ANHIC) vascular and moss tracking lists (J. Rintoul, personal communication).

Prior to the acquisition of Wagner Natural Area by the Alberta government in 1971, the Alberta Panel of the Conservation Committee of the Canadian Committee for the International Biological Programme

* Originaly suggested by Swedish ecologist Heinar Du Reitz, word "rich" meant areas rich in plant indicator species; in present days, it refers to the areas with highly minerotrophic ground water (Vitt 1982) 

FIGURE 1 : LOCATION OF WAGNER NATURAL AREA

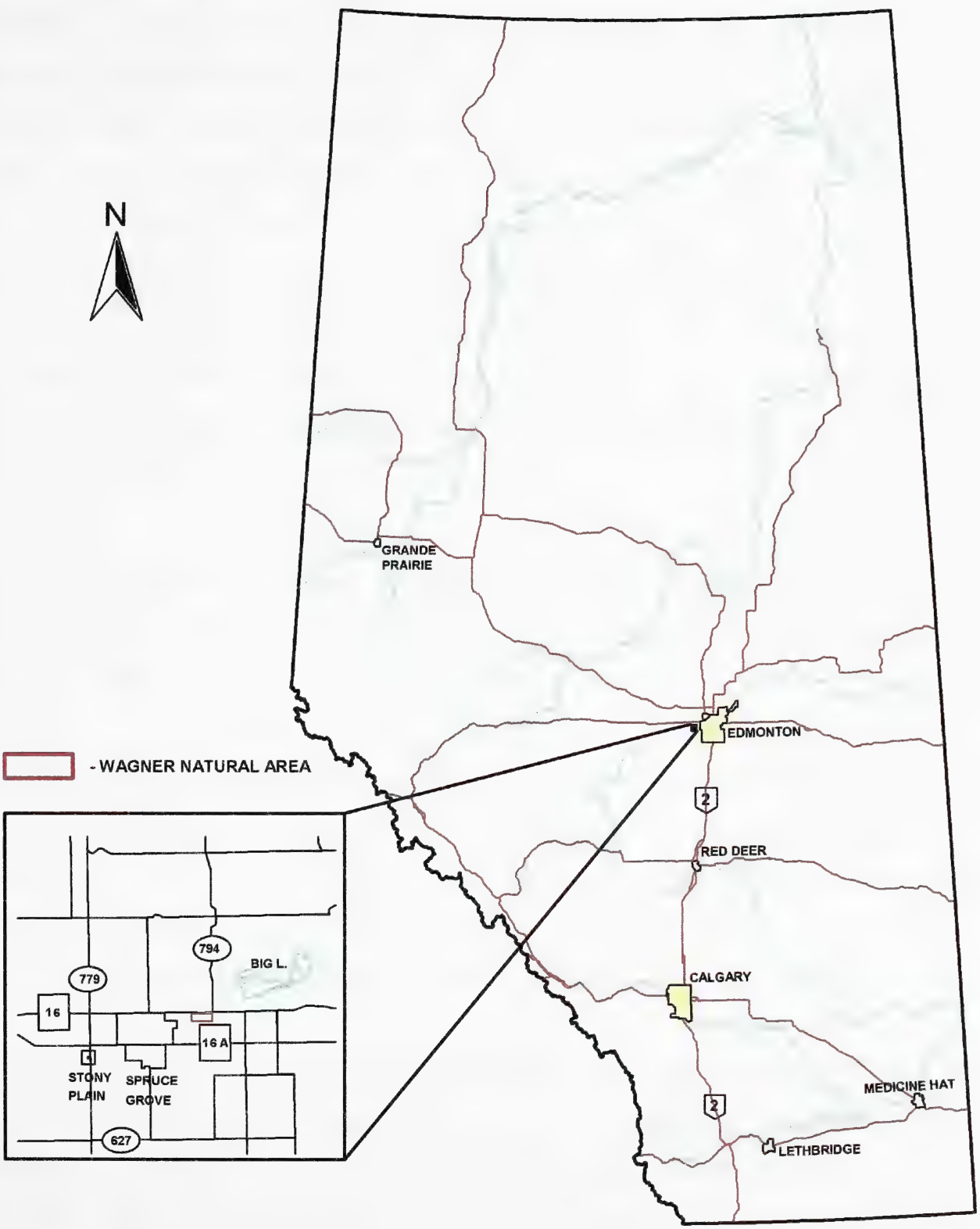



(Terrestrial Subsection) (CC-IBP-CT) surveyed the Wagner property (N1/2 7-53-23-W4M) and found it to have "very interesting calcareous fens, marl bogs and a nesting colony of Bonaparte's gulls and hence "value as a prospective nature sanctuary." The first attempt at an ecological and biological survey of the property was undertaken in 1972 by Dr. George LaRoi and Mr. A.D. Raszewski of the University of Alberta, who deposited their check-sheet of findings in the database of the IBP (correspondence and minutes in government file 09733-W01 Vol 01, Alberta Environment). For the last 25 years efforts to catalogue Wagner 's biodiversity have continued with formal or informal studies done by specialists, graduate students of the University of Alberta, summer students working in the employ of the Wagner Natural Area Society and members of the Wagner Natural Area Society and other volunteers. To date, about 317 vascular plant species are listed for the Natural Area (Appendix 7), as well as 70 mosses, 12 liverworts, 75 lichens and 69 species of fungi (Appendix 8). These numbers are likely to change as the inventorying process continues by the Wagner Natural Area Society and others. However, until the summer of 1999, no systematic biophysical inventory of the vegetation communities and associated soils had been done.

The Natural Area provides habitat for at least 3 fish, 6 herptile, 138 bird, 41 mammal, and so far as is known, more than 2000 insect species (Wagner Natural Area Society and Alberta Environmental Protection 1999).

The unusual diversity of flora and fauna within a relatively small area attracts numerous researchers to Wagner Natural Area. At the same time, because of its proximity to several urban centres (Edmonton, St. Albert, Spruce Grove), Wagner Natural Area is under increasing pressure from urbanization and recreational use. These multiple, and sometimes conflicting uses of the Natural Area may negatively impact the site in the future without careful management (WNAS and AEP 1999).

The Wilderness Areas, Ecological Reserves and Natural Areas Act (Province of Alberta 1989) provides general protective status for Wagner Natural Area. The recently completed Wagner Natural Area Management Plan (Wagner Natural Area Society and Alberta Environmental Protection 1999) provides site-specific guidelines for management. The primary goals for management of this site are: 1) to maintain natural ecological diversity, ecological processes, native species and habitats; 2) to protect 

rare and significant natural features; 3) to support environmental education use; and 4) to permit a limited range of other activities, such as research, and some recreation.

The inadequacy and poor reliability of the existing ecological baseline information for the Natural Area limits current management plan implementation. Some biophysical data were available for the site before this study; however, different levels of information have been collected at different times and for different portions of the Natural Area. The collection of baseline information for existing vegetation and soil conditions was needed as a solid foundation for appropriate management and subsequent monitoring. The purpose of this project, therefore, was to update and standardize soils and vegetation baseline information for the Natural Area.

To ensure the protection of native species and habitats, as well as rare and significant natural features of Wagner Natural Area, and because the area is also an EMAN site, the management plan proposed the implementation of a site and ecosystem monitoring program. Therefore, a second component of this project was to initiate a site and ecosystem-monitoring program by establishing permanently marked sample areas in accordance with EMAN protocol.

\subsection{Project Objectives}

The overall goal of this project was to provide spatial and attribute data for the soils and vegetation communities of Wagner Natural Area that can be used: a) to select soil and vegetation community attributes that could potentially be included in the overall biodiversity monitoring strategy for Wagner Natural Area; and (b) to determine suitable sites for monitoring elements of biodiversity (including bird, arthropod, amphibian, mammal, and plant species) using EMAN protocols.

To meet the goal, the following specific project objectives were identified:

1. Complete a detailed soil survey and produce a soils map and legend at 1:5,000 scale of Wagner Natural Area; 

2. Complete a detailed vegetation inventory and produce a vegetation community type map and legend at 1:5,000 scale of Wagner Natural Area;

3. Complete a plant community classification for Wagner Natural Area based on the field survey, previously collected data, and other work (vegetation classifications published in the relevant literature);

4. Produce a report outlining the details of field and analytical methods, study results and a discussion of possible applications of the soil and vegetation inventories to biodiversity monitoring. 



\subsection{STUDY AREA DESCRIPTION}

\subsection{Climate}

Geographically, Wagner Natural Area is situated in the north-west portion of the Central Parkland SubRegion of the Parkland Natural Region (Achuff 1994). The Sub-region is characterized by having a mean annual temperature of $2{ }^{\circ} \mathrm{C}$ and a mean annual precipitation of $350-450 \mathrm{~mm}$, with most of the precipitation occurring during the summer. In addition, there is a spatial moisture gradient within the Central Parkland Sub-Region, with the available moisture increasing from the southeast to the northwest (Vujnovic 1998). Wagner Natural Area falls within the wettest part of the Sub-region. This is further confirmed by the climate normals from the Edmonton/Stony Plain climate station, which suggest an average annual temperature of $3.1^{\circ} \mathrm{C}$, and a mean annual precipitation of $540.2 \mathrm{~mm}$ (Environment Canada 1993). Achuff (1994) and Environment Canada (1993) provide additional information on the climatic conditions of the Central Parkland Sub-Region of Alberta and for the Edmonton/Stony Plain area, respectively.

Peatlands such as those in Wagner Natural Area, and their associated vegetation communities, are uncommon within the Central Parkland Sub-Region of Alberta (Government of Alberta 1994) where they occur on their southern limit of geographical distribution as a result of microclimatic and edaphic factors.

\subsection{Bedrock and Surficial Geology}

The study area is underlain by the Horseshoe Canyon Formation (Hamilton et al.1999). The Horseshoe Canyon Formation is described as gray, feldspathic, clayey sandstone; gray bentonitic mudstone and carbonaceous shale; concretionary ironstone beds, scattered coal and bentonitic beds of variable thickness; minor limestone beds; mainly non-marine (Hamilton et al. 1999).

Surficial deposits in the region are dominantly ice-contact lacustrine and fluvial deposits (undivided) and lacustrine deposits (Shetsen 1990). The ice-contact lacustrine and fluvial deposits consist of 

gravel, sand, silt and clay, and local till up to 25 metres thick, deposited in supraglacial lakes and streams, or at margins of proglacial lakes. Topography is undulating to hummocky. The lacustrine deposits are described as silt and clay with local ice-rafted stones, up to 80 metres thick, deposited mainly in proglacial lakes, and include recent lake sediment. Topography is level to gently undulating.

\subsection{Hydrogeology}

The sand and gravel deposits resulting from the Pleistocene glaciation are the major aquifer in Wagner Natural Area (Prosser 1982). A catchment area to the south of the study site receives precipitation that soaks into the ground and, as it moves down-slope through the aquifer, dissolves some of the calcium rich sediments. In certain areas of the Natural Area, the ground surface dips below the piezometric surface resulting in a number of springs. These springs are rich in calcium carbonate and some contain sodium and sulfates as well. Calcium carbonate precipitating from the spring water is called marl. Precipitation of calcium carbonate is a result of two separate processes. First, the carbon dioxide in the spring water equilibrates with the atmosphere, resulting in the over saturation of water with calcium carbonate which was held in a solution by the raised carbon dioxide concentration (Presser 1982). Secondly, carbon dioxide is removed from the spring water through photosynthesis by Chara species (Wagner Natural Area Society 1986, Crum 1988). The temperature of the spring water is around $4^{\circ} \mathrm{C}$ all year round, preventing deep frost from penetrating into the ground in the immediate area. Prosser (1982) provides a more detailed description and diagram of the geology and hydrology of the area.

\subsection{Soils}

Wagner Natural Area lies within a transition of the Thick Black, Gray and Dark Gray Soil Zones of Central Alberta (Brierley et al. 1998). The soils were originally mapped as undifferentiated Organics and Dark Gray Luvisols developed on medium to moderately fine textured (sandy loam, silt loam or silty clay loam) glaciofluvial materials (Carvel series) (Bowser et al. 1962). More recently the soils were mapped as a mix of undifferentiated Organics and Dark Gray Luvisols developed on moderately coarse (sandy loam) glaciofluvial deposits (Brightbank series) (CAESA Soil Inventory Working Group 1998). The northwest corner of the area was mapped as having equal amounts of undifferentiated 

Organics, Eluviated and Gleyed Black Chernozemics developed on fine (clay) glaciolacustrine deposits (Malmo and Navarre series).

\subsection{Vegetation}

Two previous surveys suggested the existence of six major plant communities within Wagner Natural Area. Mussell (1979) surveyed the portion of the area located in the northern part of Section 7 and approximated the location and boundaries of the following native plant communities: 1) Sedge/Brown moss fen; 2) Black spruce/Labrador tea/Sedge/Sphagnum forest; 3) Birch/Willow/Grass forest; 4) Balsam poplar/Willow/Dewberry Forest; 5) Aspen poplar-Balsam poplar/Willow/Dewberry forest; and 6) White spruce/Willow/Bunchberry forest. Mussell (1979) also proposed 15 community sub-units based on differences in species composition. As part of an environmental impact assessment for a proposed interchange and connector road bordering the Natural Area, Spencer Environmental Management Services (1990) described and mapped plant communities for the part of the area located in Section 8 at a scale 1:2,500. The authors applied the native vegetation classification developed by Mussell (1979) and mapped the same six native vegetation communities.

Orchids represent one of the most studied groups of plants within Wagner Natural Area. While some of the orchid species are more widespread within the Natural Area (e.g. round-leaved orchid, Orchis rotundifolia), others are more commonly found in specific habitats. Tall white bog orchid (Habenaria dilatata) and hooded ladies's tresses (Spiranthes romanzoffiana) occur in wet sedge areas. Pale coralroot (Corallorhiza trifida) inhabits mainly white spruce-balsam poplar forests. Blunt-leaved bog orchid (Habenaria obtusata), bog adder's mouth (Malaxis paludosa) and heart-leaved twayblade (Listera cordata) are found mainly in black spruce-tamarack forests, while northern green bog orchid (Habenaria hyperborea) occurs commonly in many types of wetland habitats (Thormin 1982a).

Fourteen rare plant species occurring within Wagner Natural Area include flat-topped white aster (Aster umbellatus, ranked as S2*), spotted Joe-pye weed (Eupatorium maculatum, ranked as S1S2), oblongleaved sundew (Drosera anglica, ranked as S2), bog adder's-mouth (Malaxis paludosa, ranked as

* Ranking as per Alberta Natural Heritage Information Centre Definitions (Appendix 9) 

S1S2), white adder's mouth (M. monophylla, ranked as S2), slender spike-rush (Eleocharis tenuis, ranked as SU), slender beak-rush (Rhynchospora capillacea, ranked as S1), Amblyodon dealbatus (ranked as S2), Brachythecium campestre (ranked as S2), B. plumosum (ranked as S2), and Campylium radicale (ranked as S1), C. polygamum (ranked as S3), narrow-leafed chain-teeth moss (Desmatodon cernuus, ranked as S1), and brown moss (Drepanocladus crassicostatus, ranked as S1) (ANHIC 2000, J. Rintoul, personal communication). Moreover, bog adder's-mouth "is likely the rarest viable plant species in Alberta" (Fairbarns 1989).

\subsection{Wildlife}

Numerous wildlife species inhabit Wagner Natural Area. Mule Deer (Odocoileus hemionus), Whitetailed Deer (Odocoileus virginianus), Moose (Alces alces), Coyote (Canis latrans), Porcupine (Erethizon dorsatum), Masked Shrew (Sorex cinereus), Snowshoe Hare (Lepus americanus), Little Brown Bat (Myotis lucifugus), Beaver (Castor canadensis), and Muskrat (Ondatra zibethicus) are some of the mammals whose presence within the Natural Area has been confirmed (Wagner Natural Area Society 1988).

The diversity of vegetation communities within Wagner Natural Area provides habitat for numerous fauna with specific habitat requirements. For example, a number of the butterfly species reported for Wagner Natural Area can be found only in certain vegetation types. Pearl Crescent (Phyciodes tharos) and Hoary Elfin (Callophrys polios) inhabit open and shrub fen areas while White Admiral (Limenitis arthemis) lives mainly in deciduous or mixedwood forests. Black spruce forest is home to Holland's Atlantis Fritillary (Speyeria atlantis hollandi) and Mustard White (Pieris napi) is a butterfly of open fields and white spruce forests (Thormin 1982b).

The different vegetation communities also provide nesting habitats for variety of birds. The mixed white spruce-balsam poplar forests provide nesting sites for species such as Ruffed Grouse (Bonasa umbellus)*, Pileated Woodpecker (Dryocopus pileatus), Golden-crowned Kinglet (Regulus satrapa),

\footnotetext{
* Nomenclature for Latin names of birds follows American Ornithologists' Union (1998).
} 

Warbling Vireo (Vireo gilvus), Purple Finche (Carpodacus purpureus) and Swainson's Thrushe (Catharus ustulatus). Species inhabiting black spruce-tamarack forest include Boreal Chickadee (Poecile hudsonicus), Red-breasted Nuthatch (Sitta canadensis), Yellow-rumped Warbler (Dendroica coronata) and Dark-eyed Junco (Junco hyemalis). Tennessee (Vermivora peregrina) and Yellow Warblers (Dendroica petechia), Alder Flycather (Empidonax alnorum), and Common Yellowthroat (Geothlypis trichas) are some of the bird species that utilize wet willow/sedge areas. The Solitary Sandpiper (Tringa solitaria) and Lesser Yellowleg (Tringa flavipes) frequent the edges of marl ponds (Thormin 1982c).

\subsection{Natural and Anthropogenic Disturbances}

Wagner Natural Area has been influenced by various natural and man-made disturbances. Beaver activity has caused periodic flooding (WNAS and AEP 1999). Four fields (about 16 ha) were cleared for agriculture since the turn of the century; three continue to be used for hay production and one has been allowed to undergo natural succession. A dugout was constructed in the past near Atim Lake Road, and timber removal occurred around the turn of the century in the eastern portion of the Natural Area. In addition, a seismic line was established in the southwestern corner and 23 bore holes were drilled on the site (WNAS and AEP 1999). Wagner Natural Area also has two permanent trails. The trail situated in the western portion of the area, the 'Marl Pond Trail', is used frequently for educational and recreational purposes. The 'Cabin Trail' is located in the east-central portion of the Natural Area and is used only occasionally, primarily for educational purposes (e.g. orchid walks) (P. Cotterill, personal communication). 



\subsection{METHODS}

\subsection{Collection of Background Information}

A detailed review of existing literature for the Natural Area was completed in June, 1999, and all relevant available material was also obtained from the Wagner Natural Area Society as well as from the Alberta Natural Heritage Information Centre of Alberta Environment.

\subsection{Preliminary Air-photo Interpretation}

Large-scale aerial photography was not available for the study area during the preliminary interpretation phase. Therefore, 1:20,000 black-and-white aerial photography was used for initial stratification (delineation of polygons representing different soil/vegetation types) of vegetation and soils prior to the initiation of fieldwork. This allowed the soil and vegetation mapping team to develop preliminary map unit concepts. In addition, background information on surficial and bedrock geology, hydrology, soils and vegetation supported this initial stratification of the Natural Area.

\subsection{Field Survey}

The field survey consisted of four different components: plot selection and location, plot demarcation, soil data collection and sampling, and vegetation data collection and sampling.

\subsubsection{Plot Selection and Location}

Field plot selection, demarcation and field data collection were conducted over two time periods - the first (July 5 to July 13, 1999) to complete reconnaissance level plots, and the second (July 19 to July $23,1999)$ to establish more purposeful detailed (permanent monitoring) plots. The first field survey phase resulted in the establishment of 73 reconnaissance plots requiring collection of site, soil, and vegetation data. The second phase resulted in the establishment of 18 detailed plots requiring site, soil, 

and vegetation field data collection, as well as establishment of monitoring plots, and soil sampling for subsequent laboratory analyses (for mineral soils only).

Reconnaissance sites were selected using a modified systematic sampling approach. The study team established a $100 \mathrm{~m}$ (west/east) x $200 \mathrm{~m}$ (north/south) grid across the study area and located a reconnaissance plot at, or in the vicinity of, each intersecting point. Purposeful modifications of the final plot locations were carried out to avoid sampling in obvious ecotone areas, and to adequately sample all soil and vegetation types. However, attempts were made to keep these adjustments to a minimum. The initial plot was established approximately $200 \mathrm{~m}$ south and $100 \mathrm{~m}$ east of the northwest corner of the Natural Area.

Eighteen detailed sites were purposefully selected to ensure that a minimum of one plot was located in each soil and vegetation community type within the study area. At each detailed site, the study team established a $20 \mathrm{~m}$ x $20 \mathrm{~m}$ quadrat for future monitoring using the protocols described by the Ecological Monitoring and Assessment Network (EMAN) (Roberts-Pichette and Gillespie 1999). Only one plot (plot No. 14) located in the dwarf birch/sedge/moss fen, was $5 \mathrm{~m} \mathrm{x} 5 \mathrm{~m}$ in size. In this case, the decision to establish a smaller monitoring plot was based on an estimation of the minimum area needed to sample the representative species in this community, and on an attempt to avoid sampling transitional areas between this and the adjacent forested communities. The size of the monitoring quadrats is in agreement with EMAN protocols (Roberts-Pichette and Gillespie 1999) for the shrub stratum.

\subsubsection{Plot Demarcation}

The precise location of the southwest corner of each survey plot (reconnaissance and detailed) was marked with a pin-prick on the 1:5,000 color aerial photographs provided for mapping purposes after the field survey was completed. Each plot number corresponding to the field survey form was printed using black waterproof ink on the back of the aerial photograph, adjacent to the appropriate circled pinprick. 

Establishment of the $20 \mathrm{~m} \times 20 \mathrm{~m}$ EMAN quadrats followed protocols defined in Roberts-Pichette and Gillespie (1999). Each detailed plot area was surveyed in a horizontal plane using a theodolite (TOPCON DT104) with tripod and survey rod. No correction for slope was required because of the small size of the plot area and low inclinations (generally below 4\%). Upon establishment, quadrats were permanently marked at each corner with metal stakes and tagged with an aluminum tag and light blue flagging tape, both indicating plot number and corner position (SW, SE, NW or NE). The corner locations of each detailed plot were determined to the sub-meter using a Global Positioning System (GPS) (GPS positions are listed in Appendix 1). Given the precision specifications and the requirement for differential correction by EMAN protocol, a Trimble Pathfinder ProXRS receiver was used. This equipment uses the OMNI Star satellites to differentially correct positions in real time. The Pathfinder ProXRS receiver enabled the project team to incorporate Position Dilution of Precision (PDOP), Signal to Noise Ratio (SNR), and elevation masks that met or exceeded the specifications defined by EMAN protocols. On a few occasions, the PDOP was raised to access the satellites. The data capture goal was to use real time positioning whenever possible to eliminate the need for post-processing of the data. However, on numerous sites, dense and tall tree canopies prevented collection of real time data. All site positions were corrected afterwards, using base-station correction data obtained from the Resource Data Division, Alberta Environment, and from the Pleiades Data Corporation.

\subsubsection{Soil Data Collection and Sampling}

All site and soil data collection for the project was performed in accordance with standards and procedures described in the Ecological Land Survey Site Description Manual (CFS-LFS 1994) and in the Canadian System of Soil Classification (Soil Classification Working Group 1998). In addition, soil landscape models were included in the soil unit descriptions (CAESA Soil Inventory Working Group 1998).

Site selection of 73 reconnaissance and 18 detailed plots insured sampling of the range of landform and soil variability encountered within the study area. At each reconnaissance inspection site, a Site Description Form (LISD 15B, Rev. 1/97) and Soil Description Form (LISD 16B, Rev. 1/97) were completed. At the detailed plots, the Supplementary Soil Description Form (LISD 16C, Rev 3/93) was 

completed in addition to the Site Description and Soil Description Forms. The original field forms reside with the Resource Data Division, Alberta Environment.

At each inspection site, the soil profile was described in detail. In areas where mineral soils were found, soil pits were dug with a shovel to $60 \mathrm{~cm}$ and hand-augered to the $\mathrm{C}$-horizon. In organic areas, soils were hand augered to either mineral contact or to 2.2 metres (whichever came first). The pits were large enough to allow the pedologist to classify, describe and, for the detailed sites, sample the soils. At each inspection site a tarpaulin was placed on the ground surrounding the soil pit and soil was placed on the tarpaulin, so as to minimize the disturbance of vegetation surrounding the soil pit. Soil was returned to the hole in reverse order of removal, therefore all three (A, B and C) horizon materials were replaced in their appropriate location. Data recorded at each site included:

- soil order

- soil great group

- soil subgroup

- soil series

- soil phase

- humus form class and variants

- soil parent material

- effective rooting depth

- slope class

- slope position

- aspect

- stoniness class

- drainage class

- land use

- horizon type and depth (profile description)

- color

- field texture

- soil structure

- soil consistence 

All detailed soil pits were located taking into consideration the dominant characteristics represented by the sampling unit. At each detailed pit, soil samples from the midpoint of each horizon were collected and stored in appropriate sampling bags. In addition, a composite sample from the A and B horizons was collected for each of five hand-augered holes located within a two metre radius of the soil pit. The samples collected represented the dominant A and B horizons of the soil pit and were removed from approximately the same depth as that collected from the soil pit. The composite samples consist of a thorough mixture of the five samples representing each horizon. Samples were collected of all identified horizons (A, B, and C horizons) to a one meter depth. Bulk density samples were collected for identified horizons greater than $10 \mathrm{~cm}$ thick (limitation of bulk density sampling tool) to a depth of $60 \mathrm{~cm}$. All mineral soil samples were collected and stored in a freezer at the Northern Forestry Centre in Edmonton. Analysis of these samples may be conducted at a later date.

\subsubsection{Vegetation Data Collection and Sampling}

The vegetation data collection and sampling was in accordance with methods described in the Ecological Land Survey Site Description Manual (Alberta Land and Forest Services 1994), and the Alberta Forest Service Range Survey Manual (Simons and Willoughby 1990). All vegetation data was recorded on Vegetation Inventory and Vegetation Description Forms (LISD 14B and MF5, respectively). The original field forms were submitted to the Resource Data Division, Alberta Environment. At least one $35 \mathrm{~mm}$ photograph of each detailed and a number of the reconnaissance plots was taken. These photographs reside with the Resource Data Division, Alberta Environment. Some photographs of representative project area features are shown in Appendix 2.

The relevé vegetation sampling method was used to ensure that the minimum area adequately representing the plant community was sampled. A visit to the study area prior to field sampling helped to define the minimum plot size and sampling method appropriate for tree, shrub and grass dominated communities. Percent cover of all vascular and non-vascular plant species was visually estimated in $20 \mathrm{~m} \times 20 \mathrm{~m}$ plots in forested areas (including forested fen), $10 \mathrm{~m} \times 10 \mathrm{~m}$ plots in shrub dominated communities, and $5 \mathrm{~m} \times 5 \mathrm{~m}$ plots in agricultural fields. In open fen areas, belt transects covering the area equivalent to $1 \mathrm{~m}^{2}$, using a Daubenmire $(50 \mathrm{~cm} \times 20 \mathrm{~cm})$ sampling frame, were visually 

positioned. In shrub-dominated fen areas, percent cover of vascular and non-vascular plant species was visually estimated in $10 \mathrm{~m} \times 10 \mathrm{~m}$ plots. One $25 \mathrm{~m}^{2}$ detailed (EMAN) plot was sampled in a shrub dominated fen community using ten $1 \mathrm{~m}^{2}$ nested plots (this method was applied to provide more accurate data for long term monitoring).

Detailed collection of epiphyte data was not conducted because of time constraints and because vertical rather than horizontal percent cover data could not be used in the community classification for this study. Various species of epiphytic mosses and lichens inhabit trees at different ages or stages of decomposition (Soderstrom 1988). A separate study will have to be undertaken to collect detailed data on the composition of epiphyte plant species and their spatial distribution within Wagner Natural Area if this information is required.

Vegetation sampling requirements at detailed and reconnaissance plots were similar, with the exception of forested detailed plots. At forested detailed plots, substrate characteristics such as snags and downed woody debris were also noted and identified by lifeform (coniferous, deciduous) and decay class. The following decay classes were based on Soderstrom (1988):

1. wood hard, bark remaining intact;

2. wood hard, bark broken up in patches but more than $50 \%$ remaining;

3. wood hard, less than $50 \%$ bark remaining;

4. wood has started to soften, without bark, texture smooth;

5. wood soft, with small crevices and small pieces lost;

6. wood fragments lost so the outline of the trunk is deformed;

7. the outer surface of the log is hard to define, possibly with the core of harder wood;

8. completely soft without evidence of hard wood, outline indeterminable.

Age class structure and dominant overstory and understory tree heights were also determined for detailed sample plots. Age class structure was determined through the collection of several increment cores at each forested plot and breast height age was adjusted to total (origin) age using adjustment 

factors listed in Nesby (1997). Dominant overstory and understory tree heights were determined to one-meter accuracy using a laser height finder.

The majority of vascular and a number of non-vascular plant species were identified during the field sampling. All unknown vascular and non-vascular plants were collected (with the exception of rare species and orchids), appropriately labeled and cross-referenced on the field forms prior to submitting voucher samples to a qualified taxonomist for positive identification. A photograph was taken of a number of rare plants and orchid species for later taxonomic confirmation. Nomenclature for Latin and common names of vascular and non-vascular plant species followed the Alberta Plants and FungiMaster Species List and Species Group Checklists (Alberta Environmental Protection 1993). Nomenclature for Brachythecium starkei followed Anderson et al. (1990). When subspecies names were used, nomenclature for Latin names followed Hrapko (1991). Voucher samples were placed in the vascular and cryptogamic herbaria at the University of Alberta.

\subsection{Soil Data Analysis}

Soil samples were collected and stored in a freezer at the Northern Forestry Centre in Edmonton. A sample list is provided (Appendix 3). All field forms were submitted to the project coordinator for review.

\subsection{Vegetation Data Analysis and Classification}

All Vegetation Inventory and Vegetation Description forms were submitted to the project coordinator for review. The vegetation classification was not limited to potential or predicted climax communities but was rather applied to existing vegetation at any seral stage (see Braun-Blanquet 1965). Two different clustering methods (TWINSPAN and UPGMA) were employed to ensure that all species were considered in the classification, and to facilitate vegetation classification based on aerial photo interpretation and related plot data. 

TWINSPAN is a polythetic divisive method of classification (Hill 1979, Kent and Coker 1992). It clusters both plots and species and constructs a two-way table from a plot-by-species matrix. It assumes that each group of plots can be characterized by a group of species that prevail on one side of the dichotomy (differential species). Quantitative data (\% cover) are first replaced with the qualitative equivalent. This equivalent is the "pseudospecies". Any species-abundance scale is partitioned into a series of "pseudospecies" similar to a crude scale, such as the Braun-Blanquet scale of cover-abundance (Mueller-Dombois and Ellenberg 1974). The levels of abundance that are used in TWINSPAN to define the scale are called "pseudospecies cut levels" and are chosen by the user. The suitability of three different "pseudospecies" cut-levels was explored in this study: 0, 2, 5, 10, 20 (the default); 0, $5,10,20,50$; and $0,5,10,20,50,75$. TWINSPAN then proceeds with the ordination of samples by correspondence analysis (Hill 1973) and a crude division into negative and positive sides of a dichotomy. Subsequent dichotomies are constructed by using frequencies of the species on the positive and negative sides. Detailed procedures of clustering of species and plots and the construction of a species-by-plots table are given in Jongman et al. (1987).

A second clustering method uses a hierarchical agglomerative clustering that proceeds from individual samples or plots and progressively combines them based on their similarity until all samples are in one group (similarity analysis). Dissimilarity (D) is related to similarity (S) in the following way:

$$
\mathrm{D}=1-\mathrm{S}
$$

From eight similarity/dissimilarity measurements available in PC-ORD (version 4.0), the Bray-Curtis dissimilarity coefficient was chosen to obtain a dissimilarity matrix (Legendre and Legendre 1983). The Bray-Curtis coefficient is a semimetric measure that uses data on species abundance to calculate the distance between plots. The formula for the Bray-Curtis coefficient is:

$$
\mathrm{D}_{(\mathrm{i}, \mathrm{h})}=\Sigma\left|\mathrm{X}_{\mathrm{ij}}-\mathrm{X}_{\mathrm{hj}}\right| / \Sigma\left(\mathrm{X}_{\mathrm{ij}}+\mathrm{X}_{\mathrm{hj}}\right)
$$

where $D_{(i, h)}$ represents the percentage difference between quadrats $i$ and $h, X_{i j}$ is the value of species $\mathrm{j}$ for quadrat $\mathrm{i}$, and $|\mathrm{X}|$ means the absolute value of quantity $\mathrm{X}$. The property of that distance measure is that a set difference contributes the same amount to the distance, whether it occurs between rare or abundant species. Bloom (1981) emphasized the ability of the Bray-Curtis distance measure to identify accurately the true resemblance of plots along the entire range of species abundance. The agglomerative clustering method used in this study was Unweighted Arithmetical Average Clustering (UPGMA). In 

the computation of the arithmetic average for two clusters, UPGMA gives equal weights to all objects. Both the TWINSPAN and the UPGMA analyses were carried out using the PC-ORD (Version 4.0) analysis program.

\subsection{Soil Mapping and Database Development}

Soil mapping was conducted in accordance with procedures documented by the Mapping Systems Working Group (1981). Given the number of reconnaissance and detailed sites and actual size of the area, the final publication was set at 1:5,000 scale. This means that the minimum size delineation, used mostly for highly contrasting sites, like marl ponds, is approximately $0.5 \mathrm{~cm}^{2}$ (about 0.1 hectare at $1: 5,000$ scale).

The pre-stratification of soils and landforms was conducted on 1:20,000 scale, black-and-white aerial photographs. These polygons were checked in the field and modified slightly after colour 1:5,000 scale, aerial photographs became available (after fieldwork was completed). The polygon line work and positions of all reconnaissance plots were transferred onto a plot of the orthophoto base and subsequently digitized from the orthophoto base using Microstation SE and imported into ARC/INFO. The final map was registered to the provincial digital 1:20,000 base (NAD 83 datum). The final orthophoto map, complete with a title block, map scale, and controlled legend was then produced.

Once map units were delineated, an attribute database was prepared and loaded into an INFO table. The following information was included in the INFO table (Appendix 4):

- Soil unit

- Landscape model symbol

- Dominant series

- Co-dominant series (1) and co-dominant series (2)

- Significant series (1) and significant series (2)

- Dominant subgroup

- Co-dominant subgroup (1) and co-dominant subgroup (2)

- Significant subgroup (1) and significant subgroup (2) 

- Parent material (1) and parent material (2)

- Parent material texture (1) and parent material texture (2)

- Drainage

- Perviousness

\subsection{Vegetation Mapping and Database Development}

Vegetation community type/subtype polygons were first interpreted on 1:5,000 colour aerial photography. Polygon labels were neatly and legibly hand-inked onto the aerial photographs in black ink. The line work and the locations of all reconnaissance plots from the aerial photography were then transferred onto a plot of the orthophoto base and subsequently digitized off of the orthophoto base using Microstation SE and imported into ARCINFO. Polygons were then numbered in the ARCINFO and the final digital maps were produced. Considering the relatively large scale of mapping, an effort was made to avoid the use of complex vegetation units, hence, the final vegetation polygons contain only simple vegetation units. The GPS digital positional data were used to indicate the locations of the 18 detailed plots on the final map.

A digital database, which incorporates the key attributes of each map polygon, was prepared. The database was created using DBASE IV and structured so that it could be easily linked with the digital spatial data files for future Geographical Information System (GIS) analysis and presentation (Appendix 5). As specified in the study Terms of Reference, the database contains the following fields:

- A vegetation unit using the labels from the interpreted aerial photography

- Plot number

- A description of the community type/subtype

- Successional status

- Ecological moisture regime

- Nutrient regime

- Disturbance factors

- Dominant/Co-dominant Soil Unit

- Presence of standing dead timber (yes/no) 



\subsection{RESULTS AND DISCUSSION}

\subsection{Soils and Landscapes}

Soil mapping of Wagner Natural Area resulted in the creation of 46 soil polygons and 17 soil units (Table 1). The soils for the majority of the area are poorly drained (organic or peaty mineral) and enriched by secondary carbonates. These carbonates are likely deposited by lateral flow of carbonate enriched groundwater through the area. The variability of decomposition and thickness of organic deposits coupled with secondary carbonate enrichment made the classification and mapping of organics, to a large scale, difficult. That is, soil variability was high, and hence some generalizing of mapping concepts was necessary to produce the final soil map.

Moderately well drained areas are confined to the cultivated (hay) fields. The hay fields have Dark Gray Luvisols and Orthic Dark Gray Chernozems developed on medium textured glaciofluvial deposits. Some soils in the upland areas are also enriched with secondary carbonates due to groundwater discharge.

The majority of poorly and very poorly drained soils are Organic with few Gleysols present. Marl and coprogenous earth is present in many of the soils found in the area. These soils, containing limnic layers, were classified as carbonated Rego and Orthic Humic Gleysols. This classification resulted in the creation of a new Alberta soil series, 'Wagner'. The 'Wagner' soils were found in poorly and very poorly drained areas, as well as in an upland (imperfectly drained) area. This upland area (vegetation polygon \#55) was unique in that it had 30-metre high white spruce (Picea glauca) as the dominant vegetation. A hypothesis could not be formulated as to how these trees could establish and grow so well on this media and what had caused a lowering of the water table. A description of the Wagner soil series is provided (Section 4.1.5).

The surface forms were classified in accordance with procedures defined by the CAESA Soil Inventory Working Group (1998). The majority of Wagner Natural Area is level to nearly level with slopes of 



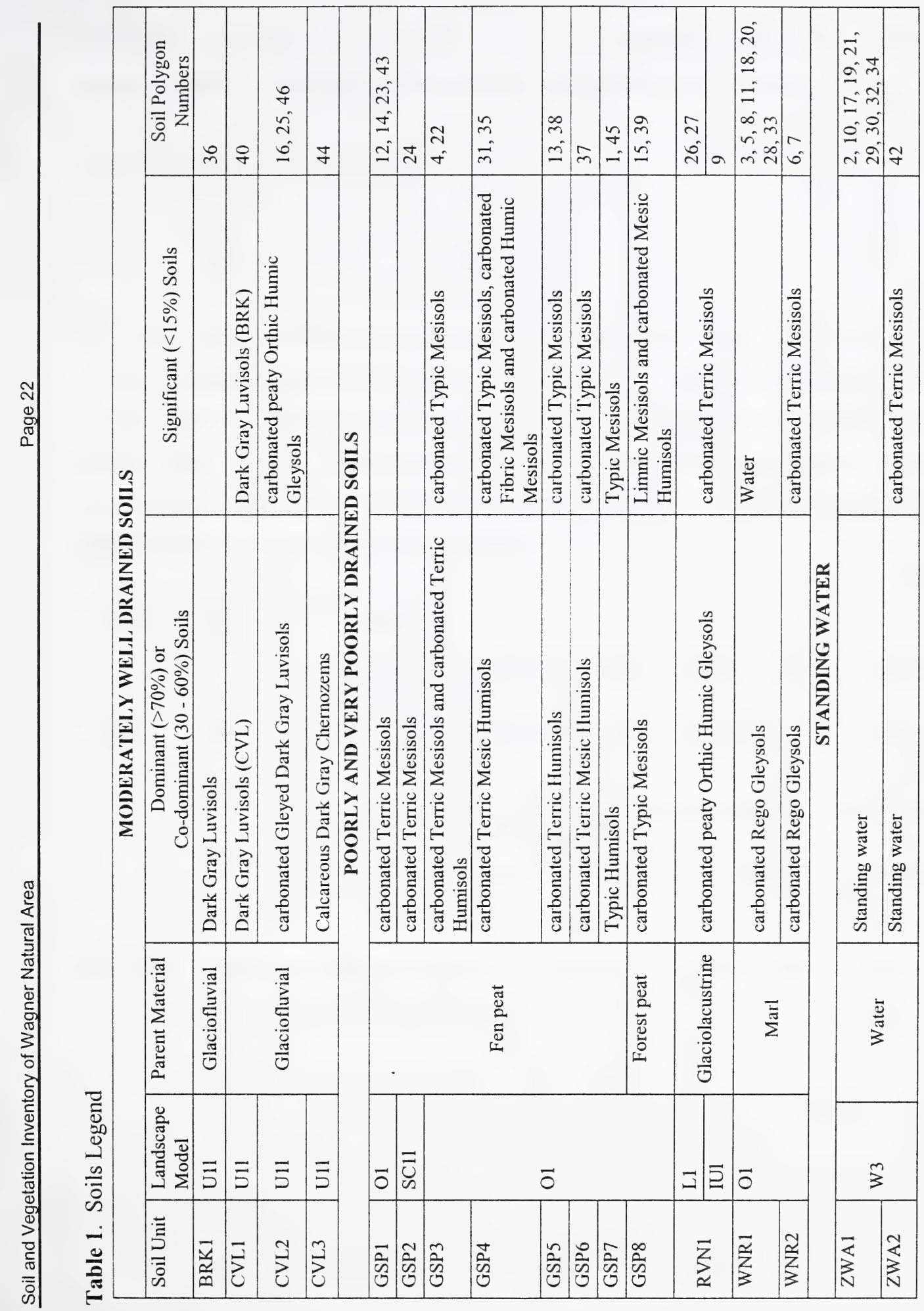

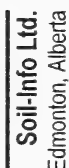



(organic) or W3 (water). Small areas of inclined and undulating slopes (IUl) are present in the northern portions of the area and one polygon was mapped as a low relief stream channel (SC11).

\subsubsection{Brightbank (BRK) Soil Unit}

\subsubsection{BRK1 Soil Unit}

The BRK1 soil unit consists of moderately well drained Dark Gray Luvisols (BRK) developed on moderately coarse textured glaciofluvial deposits. The BRK soils are characterized by a thick (15 to $20 \mathrm{~cm}$ ), friable, sandy loam textured Ap horizon overlying a thin $(10$ to $15 \mathrm{~cm})$, friable, sandy loam Ae horizon. The Ae horizon overlies a sandy clay loam textured, friable to firm, non-stony Bt horizon. The $\mathrm{Bt}$ is underlain by a weakly calcareous, sandy loam textured $\mathrm{Ck}$ horizon. A description of a typical BRK profile found in this soil unit is as follows:

$\begin{array}{lll}\text { Horizon } & \begin{array}{l}\text { Depth } \\ (\mathrm{cm}) \\ 0-20\end{array} & \begin{array}{l}\text { Description } \\ \text { Ap }\end{array} \\ \text { Very dark grayish brown (10YR 3/2 moist); sandy loam; weak fine } \\ \text { granular; friable }\end{array}$

One BRK1 soil unit was mapped (polygon \#36). The soils are found on low relief undulating (U11) landscapes having slopes of 2 to 4 percent. 



\subsubsection{Carvel (CVL) Soil Units}

\subsubsection{CVL1 Soil Unit}

The CVL1 soil unit consists of dominantly (>70\%) moderately well drained Dark Gray Luvisols (CVL) developed on medium textured glaciofluvial deposits. Minor amounts $(<15 \%)$ of Brightbank (BRK) soils developed on moderately well drained, moderately coarse textured glaciofluvial deposits occur randomly throughout the unit.

The Carvel soils are characterized by a thick (15 to $20 \mathrm{~cm}$ ), friable, loam textured Ap horizon overlying a thin $(10$ to $20 \mathrm{~cm})$, friable, sandy loam Ae horizon. The Ae horizon overlies a sandy clay loam textured, friable to firm, non-stony Bt horizon. The Bt is underlain by a sandy clay loam textured BC horizon. A description of a typical CVL profile found in this soil unit is as follows:

$\begin{array}{lll}\text { Horizon } & \begin{array}{l}\text { Depth } \\ (\mathrm{cm}) \\ 0-20\end{array} & \begin{array}{l}\text { Description } \\ \text { Ap }\end{array} \\ \text { Ae } & 20-35 & \begin{array}{l}\text { Dark grayish brown (10YR 4/2 moist); sandy loam; moderate fine } \\ \text { Branular; friable }\end{array} \\ \text { Bt } & 35-70 & \begin{array}{l}\text { Yellowish brown (10YR 5/3 moist); sandy loam; weak fine platy; friable } \\ \text { subangular blocky; firm }\end{array} \\ \text { BC } & 70-100+ & \begin{array}{l}\text { Yellowish brown (10YR 5/4 moist); sandy clay loam; moderate fine } \\ \text { subangular blocky; firm }\end{array}\end{array}$

One CVL1 soil unit was mapped in a hay field (polygon \#40). The soils are found on low relief undulating (U11) landscapes having slopes of 2 to 4 percent.

\subsubsection{CVL2 Soil Unit}

The CVL2 soil unit consists of dominantly (>70\%) imperfectly drained, carbonated Gleyed Dark Gray Luvisols (CVLcrgl) developed on medium textured glaciofluvial deposits. Minor amounts $(<15 \%)$ of carbonated peaty Orthic Humic Gleysols (RVNcrpt) developed on poorly drained, medium textured 

glaciofluvial deposits are present in depressional areas of the unit. The water table depth varies from 40 to $100 \mathrm{~cm}$.

The CVLcrgl soils are characterized by a thick (15 to $30 \mathrm{~cm})$, friable, silt loam textured, weakly calcareous Apk horizon overlying a thick (20 to $35 \mathrm{~cm}$ ), friable, loam, weakly calcareous Aek horizon. The Aek horizon overlies a silty clay loam textured, firm, non-stony, weakly calcareous Btk horizon. The Btk is underlain by a silty clay textured, moderately calcareous, weakly gleyed Ckgj horizon. A description of a typical CVLcrgl profile found in this soil unit is as follows:

\begin{tabular}{|c|c|c|}
\hline Horizon & $\begin{array}{l}\text { Depth } \\
(\mathrm{cm})\end{array}$ & Description \\
\hline Apk & $0-26$ & $\begin{array}{l}\text { Very dark gray (10YR } 3 / 1 \text { moist); silt loam; moderate fine granular; } \\
\text { friable }\end{array}$ \\
\hline Aek & $26-54$ & $\begin{array}{l}\text { Dark yellowish brown (10YR } 4 / 4 \text { moist); loam; weak fine platy; } \\
\text { friable }\end{array}$ \\
\hline Btk & $54-75$ & $\begin{array}{l}\text { Dark brown (10YR } 3 / 3 \text { moist); silty clay; moderate fine subangular } \\
\text { blocky; firm }\end{array}$ \\
\hline Ckgj & $75-120+$ & Very dark grayish brown (10YR $3 / 2$ moist); clay; massive; firm \\
\hline
\end{tabular}

Three CVL2 soil units were mapped (polygon \#16, \#25 and \#46). The soils are found on low relief undulating (U11) landscapes with slopes of 1 to 3 percent.

\subsubsection{CVL3 Soil Unit}

The CVL3 soil unit consists of dominantly $(>70 \%)$ moderately well drained Orthic Dark Gray Chernozems (CVLzz) developed on medium textured glaciofluvial deposits. Minor amounts $(<15 \%)$ of carbonated Orthic Dark Gray. Chernozems (CVLcrzz) developed on moderately well drained, medium textured glaciofluvial deposits occur at random in the unit. The CVLzz soils are characterized by a thick (15 to $30 \mathrm{~cm}$ ), friable, loam textured, weakly calcareous Apk horizon. The Apk horizon overlies a silty clay textured, firm, non-stony, weakly calcareous Btk horizon. The Btk is underlain by a silty clay textured, moderately calcareous, $\mathrm{Ck}$ horizon. A description of a CVLzz profile found in this soil unit is as follows: 



$\begin{array}{lll}\text { Horizon } & \begin{array}{l}\text { Depth } \\ (\mathrm{cm})\end{array} & \text { Description } \\ \text { Apk } & 0-25 & \begin{array}{l}\text { Very dark gray (10YR 3/1 moist); loam; moderate fine granular; } \\ \text { friable }\end{array} \\ \text { Btk } & 25-55 & \begin{array}{l}\text { Dark brown (10YR 3/3 moist); silty clay; moderate medium angular } \\ \text { blocky; firm }\end{array} \\ \text { Ck } & 55-120+ & \text { Dark brown (10YR 3/3 moist); silty clay; massive; firm }\end{array}$

One CVL3 soil unit was mapped (polygon \#44). The soils are found on low relief undulating (U11) landscapes with slopes of 2 to 4 percent.

\subsubsection{Goldenspike (GSP) Soil Units}

\subsubsection{GSP1 Soil Unit}

The GSP1 soil unit consists of dominantly ( $>70 \%)$ poorly drained carbonated Terric Mesisols (GSPcrxc) developed on moderately decomposed sedimentary peat overlying medium to moderately fine textured glaciolacustrine deposits. The water table is found within $20 \mathrm{~cm}$ of the soil surface.

The GSPcrxc soils are characterized by a thick (60 to $150 \mathrm{~cm}$ ), moderately decomposed, carbonated, Omk horizon overlying a slightly sticky, silt loam, gleyed $\mathrm{Ckg}$ horizon. The Omk horizon may contain layers of marl. A description of a typical GSPcrxc profile found in this soil unit is as follows:

$\begin{array}{lll}\text { Horizon } & \begin{array}{l}\text { Depth } \\ (\mathrm{cm}) \\ 0-20\end{array} & \begin{array}{l}\text { Description } \\ \text { Black (10YR 2/1 moist); moderately decomposed undifferentiated } \\ \text { omk }\end{array} \\ \text { Oco } & 20-50 & \begin{array}{l}\text { Dark material } \\ \text { Dark (10YR 4/1 moist); mix of organic material and marl }\end{array} \\ \text { Om } & 50-100 & \begin{array}{l}\text { Black (10YR 2/1 moist); moderately decomposed undifferentiated } \\ \text { organic material } \\ \text { Black (10YR 2/1 moist); silt loam; massive; slightly sticky }\end{array}\end{array}$



Four GSP1 soil units were mapped (polygon \#12,\#14,\#23 and \#43). The soils are found on level organic $(\mathrm{Ol})$ landscapes having slopes of $<1$ percent.

\subsubsection{GSP2 Soil Unit}

The GSP2 soil unit consists of dominantly ( $>70 \%)$ poorly drained carbonated Terric Mesisols (GSPcrxc) developed on moderately decomposed fen peat overlying medium to moderately fine textured glaciolacustrine deposits. The water table is found within 20 to $90 \mathrm{~cm}$ of the soil surface.

The GSPcrxc soils are characterized by a thick (100 to $150 \mathrm{~cm}$ ), moderately decomposed, carbonated, Omk horizon overlying a slightly sticky, silt loam, gleyed, moderately calcareous $\mathrm{Ckg}$ horizon. The Omk horizon may contain layers of marl.

One GSP2 soil unit was mapped (polygon \#24). The soils are found on a stream channel with slopes $<9$ percent (SC11). The only difference between GSP2 and GSP1 soil units is that GSP2 are located on a different surface form.

\subsubsection{GSP3 Soil Unit}

The GSP3 soil unit consists of co-dominantly (30 to 60\%) each of poorly drained carbonated Terric Mesisols (GSPcrxc) developed on moderately decomposed fen peat deposits and carbonated Terric Humisols (GSPcrxczh) developed on highly decomposed fen peat overlying medium to moderately fine textured glaciolacustrine deposits. Minor amounts $(<15 \%)$ of carbonated Typic Mesisols (GSPcr) developed on poorly drained, moderately decomposed organic deposits occur at random in the unit. The water table is found within $20 \mathrm{~cm}$ of the soil surface.

The GSPcrxc soils are characterized by having a thick $(60$ to $150 \mathrm{~cm}$ ), moderately decomposed, carbonated, Omk horizon overlying a slightly sticky, silt loam, gleyed, moderately calcareous Ckg horizon. The Omk horizon may contain layers of marl. A description of a typical GSPcrxc profile found in this soil unit is as follows: 



$\begin{array}{lll}\text { Horizon } & \begin{array}{l}\text { Depth } \\ (\mathrm{cm}) \\ 0-20\end{array} & \begin{array}{l}\text { Description } \\ \text { Black (10YR 2/1 moist); moderately decomposed undifferentiated } \\ \text { omkanic material }\end{array} \\ \text { Oco } & 20-50 & \begin{array}{l}\text { Dark gray (10YR 4/1 moist); mix of organic material and marl } \\ \text { Om }\end{array} \\ \text { Ckg } & 100+100 & \begin{array}{l}\text { Black (10YR 2/1 moist); moderately decomposed undifferentiated } \\ \text { organic material } \\ \text { Black (10YR 2/1 moist); silt loam; massive; slightly sticky }\end{array}\end{array}$

The GSPcrxczh soils are characterized by having a thick $(100$ to $150 \mathrm{~cm}$ ), highly decomposed, carbonated Ohk horizon overlying a sticky, silty clay to clay, gleyed, moderately calcareous $\mathrm{Ckg}$ horizon. The Ohk horizon may contain layers of marl. A description of a typical GSPcrxczh profile found in this soil unit is as follows:

$\begin{array}{lll}\text { Horizon } & \begin{array}{l}\text { Depth } \\ (\mathrm{cm})\end{array} & \text { Description } \\ \text { Ohco } & 0-100 & \begin{array}{l}\text { Black (10YR 2/1 moist); highly decomposed undifferentiated organic } \\ \text { material }\end{array} \\ \text { Ckg } & 100-120+ & \text { Black (10YR 2/1 moist); clay; massive; sticky }\end{array}$

Two GSP3 soil units were mapped (polygon \#4 and \#22). The soils are found on level organic (O1) landscapes having slopes of $<1$ percent.

\subsubsection{GSP4 Soil Unit}

The GSP4 soil unit consists of dominantly (> 70\%) poorly drained carbonated Terric Mesic Humisols (GSPcrxczh) developed on moderately to highly decomposed fen peat overlying moderately fine to fine textured glaciolacustrine deposits. Minor amounts ( $<15 \%$ each) of carbonated Typic Mesisols (GSPcr), carbonated Fibric Mesisols (GSPcrzf) and carbonated Humic Mesisols occur at random in the unit. The water table is found within $20 \mathrm{~cm}$ of the soil surface. 

The GSPcrxczh soils are characterized by having a thick (60 to $90 \mathrm{~cm}$ ), moderately decomposed, carbonated Omk horizon overlying a thick (60 to $90 \mathrm{~cm}$ ) highly decomposed, carbonated Ohk horizon. The Ohk horizon overlies the sticky, clay, gleyed, moderately calcareous $\mathrm{Ckg}$ horizon. A description of a typical GSPcrxczh profile found in this soil unit is as follows:

$\begin{array}{lll}\text { Horizon } & \begin{array}{l}\text { Depth } \\ (\mathrm{cm})\end{array} & \text { Description } \\ \text { Omk } & 0-70 & \begin{array}{l}\text { Very dark brown (10YR 2/2 moist); moderately decomposed } \\ \text { undifferentiated organic material }\end{array} \\ \text { Ohk } & 70-140 & \begin{array}{l}\text { Very dark brown (10YR 2/2 moist); highly decomposed } \\ \text { undifferentiated organic material }\end{array} \\ \text { Ckg } & 140-180+ & \text { Dark gray (2.5Y 4/0 moist); clay; massive; sticky }\end{array}$

Two GSP4 soil units were mapped (polygon \#31 and \#35). The soils are found on level organic (Ol) landscapes having slopes of $<1$ percent.

\subsubsection{GSP5 Soil Unit}

The GSP5 soil unit consists of dominantly (> 70\%) poorly drained carbonated Terric Humisols (GSPcrxczh) developed on highly decomposed fen peat overlying medium to moderately fine textured glaciolacustrine deposits. The water table is found within $50 \mathrm{~cm}$ of the soil surface.

Minor amounts ( $<15 \%)$ of carbonated Terric Mesisols (GSPcrxc) occur at random in the unit. The GSPcrxczh soils are characterized by having a thick (50 to $75 \mathrm{~cm}$ ), highly decomposed, carbonated Ohk overlying a sticky, silt loam to silty clay, gleyed, moderately calcareous $\mathrm{Ckg}$ horizon. A description of a typical GSPcrxczh profile found in this soil unit is as follows: 



\begin{tabular}{|c|c|c|}
\hline Horizon & $\begin{array}{l}\text { Depth } \\
(\mathrm{cm})\end{array}$ & Description \\
\hline Ohk & $0-60$ & $\begin{array}{l}\text { Very dark brown (10YR } 2 / 2 \text { moist); highly decomposed } \\
\text { undifferentiated organic material }\end{array}$ \\
\hline Ckg1 & $60-75$ & Very dark gray (10YR 3/1 moist); loam; massive; sticky \\
\hline Ckg2 & $75-90$ & Light gray (10YR 7/2 moist); silt loam; massive; slightly to non-sticky \\
\hline Ckg3 & $90-120$ & Gray (10YR 5/1 moist); silty clay loam; massive; sticky \\
\hline
\end{tabular}

Two GSP5 soil units were mapped (polygon \#13 and \#38). The soils are found on level organic (Ol) landscapes having slopes of $<1$ percent.

\subsubsection{GSP6 Soil Unit}

The GSP6 soil unit consists of dominantly (> 70\%) poorly drained carbonated Terric Mesic Humisols (GSPcrxczz) developed on moderately to highly decomposed fen peat overlying moderately fine to fine textured glaciolacustrine deposits. Minor amounts $(<15 \%)$ of carbonated Terric Mesisols (GSPcrxc) occur at random in the unit. The water table is found within $20 \mathrm{~cm}$ of the soil surface.

The GSPcrxczz soils are characterized by having a thick $(40 \mathrm{~cm})$, moderately decomposed, carbonated Omk overlying a thick $(100 \mathrm{~cm})$ carbonated, highly decomposed Ohk horizon. The Ohk is underlain by a sticky, clay, gleyed, moderately calcareous Ckg horizon. A description of a typical GSPcrxczz profile found in this soil unit is as follows:

$\begin{array}{lll}\text { Horizon } & \begin{array}{l}\text { Depth } \\ (\mathrm{cm}) \\ 0-40\end{array} & \begin{array}{l}\text { Description } \\ \text { Very dark brown (10YR 2/2 moist); moderately decomposed } \\ \text { Undifferentiated organic material }\end{array} \\ \text { Ohk } & 40-140 & \begin{array}{l}\text { Very dark brown (10YR 2/2 moist); highly decomposed } \\ \text { undifferentiated organic material }\end{array} \\ \text { Ckg } & 140-175 & \begin{array}{l}\text { Dark gray (2.5Y 4/0 moist); clay; massive; sticky } \\ \text { Ond }\end{array}\end{array}$



One GSP6 soil unit was mapped (polygon \#37). The soils are found on level organic (Ol) landscapes having slopes of $<1$ percent.

\subsubsection{GSP7 Soil Unit}

The GSP7 soil unit consists of dominantly (> 70\%) poorly drained Typic Humisols (GSPzh) developed on moderately to highly decomposed fen peat. Minor amounts ( $<15 \%)$ of Typic Mesisols (GSP) occur at random in the unit. The water table is found within $20 \mathrm{~cm}$ of the soil surface.

The GSPzh soils are characterized by having a thick $(30 \mathrm{~cm})$, slightly decomposed Of horizon overlying a thick $(>170 \mathrm{~cm})$ carbonated, highly decomposed Ohk horizon. A description of a typical GSPzh profile found in this soil unit is as follows:

$\begin{array}{lll}\text { Horizon } & \begin{array}{l}\text { Depth } \\ (\mathrm{cm})\end{array} & \text { Description } \\ \text { Of } & 0-30 & \begin{array}{l}\text { Very dark grayish brown (10YR 3/2 moist); slightly deco } \\ \text { undifferentiated organic material }\end{array} \\ \text { Ohk } & 30-220+ & \begin{array}{l}\text { Very dark brown (10YR 2/2 moist); highly decomposed } \\ \text { undifferentiated organic material }\end{array}\end{array}$

Two GSP7 soil units were mapped (polygon \#1 and 45). The soils are found on level organic (Ol) landscapes having slopes of $<1$ percent.

\subsubsection{GSP8 Soil Unit}

The GSP8 soil unit consists of dominantly (> 70\%) very poorly drained, carbonated Typic Mesisols (GSPcr) developed on moderately decomposed forest peat. Minor amounts ( $<15 \%$ each) of Limnic Mesisols (GSPcrzz) and carbonated Mesic Humisols (GSPcrzh) occur at random in the unit. The water table is at the soil surface.

The GSPcr soils are characterized by having a thick ( 40 to $80 \mathrm{~cm}$ ), moderately decomposed Omk horizon overlying a thick (120 to $200 \mathrm{~cm}$ ) carbonated, highly decomposed Ocoh horizon. A moderately 

calcareous, slightly sticky, loam, gleyed Ckg horizon, underlies the Ocoh. A description of a typical GSPcr profile found in this soil unit is as follows:

\begin{tabular}{|c|c|c|}
\hline Horizon & $\begin{array}{l}\text { Depth } \\
(\mathrm{cm})\end{array}$ & Description \\
\hline Omk & $0-60$ & $\begin{array}{l}\text { Black (10YR } 2 / 1 \text { moist); moderately decomposed undifferentiated } \\
\text { organic material }\end{array}$ \\
\hline Ocoh & $60-220$ & $\begin{array}{l}\text { Black (10YR } 2 / 1 \text { moist); highly decomposed undifferentiated organic } \\
\text { material mixed with marl }\end{array}$ \\
\hline $\mathrm{Ckg}$ & $220-230+$ & Black (10YR 2/1 moist); loam; massive; slightly sticky \\
\hline
\end{tabular}

Two GSP8 soil units were mapped (polygon \#15 and 39). The soils were found on level organic (Ol) landscapes having slopes of $<1$ percent.

\subsubsection{Raven (RVN) Soil Units}

\subsubsection{RVN1 Soil Unit}

The RVN1 soil unit consists of dominantly (>70\%) poorly drained, carbonated peaty Orthic Humic Gleysols (RVNcrpt) developed on fine textured glaciolacustrine deposits. Minor amounts $(<15 \%)$ of carbonated Terric Mesisols (GSPcrxc) occur at random in the unit. The water table is found at 20 to $50 \mathrm{~cm}$ below the soil surface.

The RVNcrpt soils are characterized by having a thick (15 to $30 \mathrm{~cm}$ ), moderately decomposed Omk horizon overlying a carbonated, silty clay, gleyed Bgk horizon. The Bgk is underlain by moderately calcareous, clay, sticky, gleyed Ckg horizon. A description of a typical RVNcrpt profile found in this soil unit is as follows: 



$\begin{array}{lll}\text { Horizon } & \begin{array}{l}\text { Depth } \\ (\mathrm{cm}) \\ 0-21\end{array} & \begin{array}{l}\text { Description } \\ \text { Bmk }\end{array} \\ \text { Black (10YR 2/1 moist); moderately decomposed undifferentiated } \\ \text { organic material }\end{array}$

Three RVN1 soil units were mapped. The soils are found on level (L1) landscapes having slopes of $<$ 1 percent (polygon \#26 and \#27) and low relief inclined and undulating (IU1) landscapes having slopes of 2 to 4 percent (polygon \#9).

\subsubsection{Wagner (WNR) Soil Units}

\subsubsection{WNR1 Soil Unit}

The WNR1 soil unit consists of dominantly ( $>70 \%)$ very poorly drained, carbonated Rego Gleysols (WNR) developed on marl deposits. Minor amounts ( $<15 \%$ each) of open water and of carbonated Terric Mesisols (GSPcrxc) occur at random in the unit. The water table is found at the soil surface.

The WNR soils are characterized by having a thick (> $100 \mathrm{~cm}$ ), Ckg horizon (marl) overlying mixed layers of fen peat (Ofk, Omk or Ohk). A description of a typical WNR profile found in this soil unit is as follows:

$\begin{array}{lll}\text { Horizon } & \begin{array}{l}\text { Depth } \\ (\mathrm{cm}) \\ 0-170\end{array} & \text { Description } \\ \text { Ckg } & \text { White (10YR 8/1 dry); marl; non-sticky } \\ \text { Ofk } & 170-220+\begin{array}{l}\text { Dark brown (10YR 3/3 moist); slightly decomposed undifferentiated } \\ \text { organic material }\end{array}\end{array}$

Eight WNR1 soil units were mapped (polygon \#3, \#5, \#8, \#11, \#18, \#20,\#28 and \#33). The soils are found on level ( $\mathrm{Ll}$ ) landscapes having slopes of $<1$ percent. 



\subsubsection{WNR2 Soil Unit}

The WNR2 soil unit consists of dominantly ( $>70 \%)$ imperfectly to poorly drained, carbonated Rego Gleysols (WNR) developed on marl deposits. Minor amounts $(<15 \%)$ of carbonated Terric Mesisols (GSPcrxc) occur at random in the unit. The water table is found at 100 to $150 \mathrm{~cm}$ below the soil surface.

The WNR soils in this unit are characterized by having a thin forest litter layer and a weakly developed Ah horizon overlying a thick $(>100 \mathrm{~cm}) \mathrm{Ckg}$ horizon (marl). Mixed layers of fen peat (Ofk, Omk or Ohk) underlie the Ckg. The WNR2 soils differ from WNR1 soils in that the WNR2 soils are imperfectly drained, have a LF layer and a weakly developed Ah horizon. A description of a WNR profile found in this soil unit is as follows:

\begin{tabular}{|c|c|c|}
\hline Horizon & $\begin{array}{l}\text { Depth } \\
(\mathrm{cm})\end{array}$ & Description \\
\hline $\mathrm{LF}$ & $12-0$ & Semi-decomposed leaf litter \\
\hline Ahk & $0-13+$ & Black (10YR 2/1 moist); silt loam; weak fine platy; friable \\
\hline Ckg1 & $13-31+$ & Very pale brown (10YR $7 / 3$ moist); silt loam; weak fine platy; friable \\
\hline Ckg2 & $31-50$ & $\begin{array}{l}\text { Dark brown ( } 7.5 \text { YR } 3 / 4 \text { moist) with strong brown }(7.5 \text { YR } 4 / 6 \\
\text { mottles); silt loam; weak fine platy; friable }\end{array}$ \\
\hline Ckg3 & $50-90$ & $\begin{array}{l}\text { Light yellowish brown (10YR } 6 / 4 \text { moist) with strong brown ( } 7.5 \text { YR } \\
4 / 6 \text { mottles); silt loam; weak fine platy; friable }\end{array}$ \\
\hline Ckg4 & $90-110$ & $\begin{array}{l}\text { Gray ( } 10 \text { YR } 5 / 1 \text { moist) with light brownish gray ( } 10 \text { YR } 6 / 2 \text { mottles); } \\
\text { silt loam; weak fine platy; friable }\end{array}$ \\
\hline
\end{tabular}

Two WNR2 soil units were mapped (polygon \#6 and \#7). The soils were found on level (Ll) landscapes having slopes of $<1$ percent. 



\subsubsection{Water (ZWA) Units}

\subsubsection{ZWA1 Soil Unit}

The ZWA1 unit consists of dominantly (>90\%) open water. Nine ZWA1 units were mapped (polygon $\# 2$, \#10,\#17,\#19,\#21,\#29, \#30,\#32 and \#34). The unit was found on level (W3) landscapes having slopes of $<0.5$ percent.

\subsubsection{ZWA2 Soil Unit}

The ZWA1 unit consists of dominantly (> 80\%) open water. Minor amounts of carbonated Terric Mesisols developed on moderately decomposed undifferentiated organic material are found in the unit. One ZWA2 unit was mapped (polygon \#42). The unit was found on level (W3) landscapes having slopes of $<0.5$ percent.

\subsection{Native Vegetation Communities and Miscellaneous Cover Types}

The total number of plant species recorded in this study was 256, of which 203 were vascular plants, 40 were mosses and liverworts, and 13 were lichens. All scientific and common names for vascular and non-vascular plant species with associated seven-letter codes are listed in Appendix 6. Aerial photo interpretation and related plot data, supported by two computer data analyses, resulted in the identification of eight native vegetation community types and five miscellaneous cover types. The eight native vegetation community types were further subdivided into 20 subtypes (Table 2) based on differences in the dominant species of the understory (shrub, herb and moss layers).

All vegetation community types/subtypes were named as follows: dominant plant species in each structural vegetation layer or stratum are listed and separated by forward slashes $(/)$ indicating a change to a different layer. A dash (-) is used to name co-dominants within the same stratum. Two-letter codes for tree species are used in the tree component of the abbreviated names for vegetation community subtypes. 

Table 2. Native vegetation community types, subtypes, and miscellaneous cover types mapped within Wagner Natural Area.

\begin{tabular}{|c|c|c|c|}
\hline \multicolumn{4}{|c|}{ Native Vegetation Communities } \\
\hline Type Code & Type Name & $\begin{array}{c}\text { Subtype } \\
\text { Code }\end{array}$ & Subtype Name \\
\hline \multirow[t]{2}{*}{$\overline{\mathrm{BP}}$} & \multirow{2}{*}{$\begin{array}{l}\text { Alaska birch-balsam } \\
\text { poplar }\end{array}$} & BP1 & $\mathrm{Bw}-\mathrm{Pb} /$ dewberry/sedge \\
\hline & & BP2 & $\mathrm{Bw}-\mathrm{Pb} /$ bunchberry \\
\hline \multirow[t]{3}{*}{ FE } & \multirow[t]{3}{*}{ fen } & FE1 & bulrush-sedge/moss fen \\
\hline & & FE2 & dwarf birch/sedge/moss fen \\
\hline & & FE3 & Lt-Sb/dwarf birch-willow/sedge/moss fen \\
\hline \multirow[t]{4}{*}{$\mathrm{PA}$} & \multirow[t]{4}{*}{ balsam poplar-aspen } & PA1 & $\mathrm{Pb}-\mathrm{Aw} /$ dewberry \\
\hline & & PA2 & $\mathrm{Pb}-\mathrm{Aw} /$ willow/bluejoint \\
\hline & & PA3 & $\mathrm{Pb}-\mathrm{Aw} / \mathrm{bluejoint-sedge}$ \\
\hline & & PA4 & $\mathrm{Pb}-\mathrm{Aw} / \mathrm{dogwood}$ \\
\hline \multirow[t]{2}{*}{ SL } & \multirow[t]{2}{*}{ black spruce-tamarack } & SL1 & Sb-Lt/Labrador tea/feather moss \\
\hline & & SL2 & $\begin{array}{l}\text { Sb-Lt/Labrador tea/feather moss-peat } \\
\text { moss }\end{array}$ \\
\hline \multirow[t]{5}{*}{ SP } & \multirow{5}{*}{$\begin{array}{l}\text { white spruce-balsam } \\
\text { poplar }\end{array}$} & SP1 & $\mathrm{Sw}-\mathrm{Pb} /$ dewberry \\
\hline & & SP2 & $\mathrm{Sw}-\mathrm{Pb} /$ willow-dogwood \\
\hline & & SP3 & Sw-Pb/bunchberry/horsetail \\
\hline & & SP4 & $\mathrm{Sw}-\mathrm{Pb} /$ clover \\
\hline & & SP5 & $\mathrm{Sw}-\mathrm{Pb} / \mathrm{moss}$ \\
\hline \multirow[t]{2}{*}{ SS } & \multirow{2}{*}{$\begin{array}{l}\text { white spruce-black } \\
\text { spruce }\end{array}$} & SS1 & $\mathrm{Sw}-\mathrm{Sb} /$ dewberry/sedge/feather moss \\
\hline & & SS2 & $\mathrm{Sw}-\mathrm{Sb} /$ horsetail \\
\hline SW & white spruce & SW & Sw/bunchberry/feather moss \\
\hline WS & willow & WS & willow/sedge-bluejoint \\
\hline \multicolumn{4}{|c|}{ Miscellaneous Cover Types } \\
\hline Code & \multicolumn{3}{|c|}{ Name } \\
\hline $\mathrm{AF}$ & \multicolumn{3}{|c|}{ abandoned field } \\
\hline $\mathrm{BE}$ & \multicolumn{3}{|c|}{ beaver pond and associated flooding area } \\
\hline $\mathrm{CL}$ & \multicolumn{3}{|c|}{ clearing } \\
\hline $\mathrm{HF}$ & \multicolumn{3}{|l|}{ hay field } \\
\hline MP & \multicolumn{3}{|l|}{ marl pond } \\
\hline
\end{tabular}



These are:
Aw (aspen)
$\mathrm{Pb}$ (balsam poplar)
Bw (Alaska birch)
$\mathrm{Sb}$ (black spruce)
Lt (tamarack)
Sw (white spruce)

\subsubsection{Floristic and Ecological Characteristics of Native Vegetation Communities}

Native vegetation communities described in this study can be grouped within five broader vegetation categories: deciduous, mixedwood, coniferous, shrubland, and wetland communities. The DECIDUOUS vegetation category includes all vegetation communities that are dominated by deciduous tree species (balsam poplar, Alaska birch, aspen). The MIXEDWOOD category includes communities where both deciduous and coniferous tree species dominate the tree stratum. Communities dominated by the coniferous tree species only (white spruce, black spruce, tamarack) are grouped into CONIFEROUS category. The SHRUBLAND category includes one vegetation community that does not have an overstory tree canopy but is dominated by different species of willows. Finally, the WETLAND category includes fen vegetation communities.

\subsubsection{Deciduous Communities}

\section{$\underline{\mathrm{Bw}-\mathrm{Pb} / \text { dewberry/sedge (BP1) }}$}

A significant cover of Alaska birch (Betula neoalaskana) intermixed with balsam poplar (Populus balsamifera), aspen (Populus tremuloides), and white spruce characterizes this community (Plate 1). Dewberry (Rubus pubescens) dominates the shrub stratum, accompanied by bunchberry (Cornus canadensis) and common Labrador tea (Ledum groenlandicum). Two-seeded sedge (Carex disperma) dominates significant portions of the herb layer; twin-flower (Linnaea borealis L. ssp. americana), bishop's cap (Mitella nuda), tall lungwort (Lungwort paniculata), and three-leaved Solomon's-seal (Smilacina stellata) are some of the additional species in the herb layer. Common horsetail (Equisetum 

arvense) frequently dominates wetter depressions. Feather mosses cover most of the ground. Subhygric moisture conditions and permesotrophic to mesotrophic nutrient regimes characterize soils occupied by this community. The water table varied from $5 \mathrm{~cm}$ to $80 \mathrm{~cm}$ below the soil surface and carbonates were generally close to the soil surface. Three soils described within the white birch-balsam poplar/dewberry/sedge forests included carbonated peaty Orthic Humic Gleysols, carbonated Terric Humisols and carbonated Terric Mesisols (soil units RVN1 and GSP3). This community subtype covers only small portions of the eastern half of Wagner Natural Area (Map 1, polygon \#25 and \#65).

\section{$\underline{B w}-\mathrm{Pb} /$ bunchberry $(\mathrm{BP} 2)$}

This community subtype has a more open tree canopy and older, taller trees compared to BP1 (Plate 2). Bunchberry dominates the shrub layer, accompanied by various other shrub species, of which dewberry, wild red raspberry (Rubus idaeus) and red-osier dogwood (Cornus stolonifera) have the highest cover. Wild sarsaparilla (Aralia nudicaulis) and sedges such as bristle-stalked sedge (Carex leptalea) and sheathed sedge (Carex vaginata) dominate the herb layer, while bishop's cap, tall lungwort, wild strawberry (Fragaria virginiana Duchesne ssp. glauca), and numerous other forb and sedge species occur at low covers. Leaf litter covers most of the ground while various brown moss and feather moss species make up small portions of the total ground cover. Carbonated Rego Gleysols (soil unit WNR2) with hygric to subhygric moisture conditions and a permesotrophic nutrient regime characterize this plant community. The water table was located at about $90 \mathrm{~cm}$ below the soil surface. Carbonates were found within $40 \mathrm{~cm}$ of the soil surface. One white birch-balsam poplar/bunchberry forest community is located in the very eastern portion of the study area (Map 1, polygon \#54).

\section{$\underline{\mathrm{Pb}-\mathrm{Aw} / \text { dewberry (PA1) }}$}

Co-dominance of balsam poplar and aspen with a sporadic presence of white spruce and Alaska birch characterizes this community. Dewberry, in association with wild red raspberry and red-osier dogwood, generally dominates the shrub layer. Palmate-leaved coltsfoot (Petasites palmatus), wild sarsaparilla and tall lungwort are some of the numerous forbs occupying the herb layer. Sedge species, such as Dewey's sedge (Carex deweyana) and hair-like sedge (Carex capillaris) are frequently associated with 

the presence of white spruce and Alaska birch. Mosses are rare and leaf litter covers most of the ground. Subhygric to mesic moisture conditions and mesotrophic to permesotrophic nutrient regimes characterize the soils occupied by the balsam poplar-aspen/dewberry community. Water tables were generally located at more than 1.5 meters below the soil surface. Carbonates were found close to the soil surface in most of the soil pits. Soils described in PA1 include carbonated Gleyed Dark Gray Luvisols, carbonated Terric Humisols and carbonated Terric Mesisols (soil units CVL2, GSP1, GSP2, GSP3, GSP5). Balsam poplar-aspen/dewberry forest is found adjacent to the hay fields and within the southwestern portion of the study area (Map 1, polygon \#38, \#42, \#60, \#62, \#83 and \#98).

\section{$\underline{\mathrm{Pb}-\mathrm{Aw} / \mathrm{willow} / \mathrm{bluejoint}(\mathrm{PA} 2)}$}

Scattered patches of balsam poplar and aspen in the overstory and the dominance of various willow species in the shrub layer characterizes this community subtype. Beaked willow (Salix bebbiana) and false mountain willow (Salix pseudomonticola) are two of the dominant willow species. Bluejoint (Calamogrostis canadensis) and fowl manna grass (Glyceria striata) frequently dominate the herb layer in association with wire rush (Juncus balticus), various sedges, and numerous forb species, such as star-flowered Solomon's-seal, marsh marigold (Caltha palustris) and yellow avens (Geum aleppicum). Leaf litter covers most of the ground with the exception of the small, scattered areas with shallow standing water. Subhygric to hygric moisture conditions and a permesotrophic nutrient regime characterize the soils within the area. The depth of the water table in soil pits averaged $40 \mathrm{~cm}$. Carbonates were generally found near the soil surface. Soils found within this unit include carbonated Terric Mesisols and carbonated Terric Humisols (soil units GSP5 and GSP1). Two PA2 units occur adjacent to the agricultural field located in the western portion of the study area and another borders the eastern study area boundary (Map 1, polygon \#14, \#56,\#73 and \#93).

\section{$\underline{\mathrm{Pb}-\mathrm{Aw} / \mathrm{bluejoint} \text {-sedge (PA3) }}$}

Balsam poplar and aspen dominate the tree stratum in this community. The shrub layer consists mainly of red-osier dogwood associated with a number of other species such as wild and northern black currants (Ribes americanum and $R$. hudsonianum, respectively), beaked willow, and dewberry. 

Bluejoint covers extensive areas accompanied by scattered grass and forb species including awned sedge (Carex atherodes), spotted touch-me-not (Impatiens capensis), purple-stemmed aster (Aster puniceus), and common nettle (Urtica dioica L. ssp. gracilis). Carbonated Terric Mesic Humisols (soil unit GSP6) occur within this community with subhygric to subhydric moisture conditions and a permesotrophic nutrient regime. Carbonates and the water table were found near the soil surface. The PA3 community subtype is limited to one small area within the northwestern portion of the study site (Map 1, polygon \#96).

\section{$\underline{\mathrm{Pb}-\mathrm{Aw} / \mathrm{dog} w o o d(\mathrm{PA} 4)}$}

This community differs from the PA3 community because of a substantially higher cover of red-osier dogwood and a much lower abundance of bluejoint in the herb layer (Plate 3). Litter covers most of the ground, with Plagiomnium ellipticum and Brachythecium turgidum occasionally present in wetter depressions. Subhygric to hygric moisture conditions and a permesotrophic to mesotrophic nutrient regime characterize the soils of the PA4 community subtype. The water table was generally located more than a meter below the soil surface. Carbonates were found close to the soil surface in all pits. Soils described within the PA4 map units are carbonated Terric Mesisols, carbonated Terric Mesic Humisols and carbonated Typic Mesisols (soil units GSP4, GSP1 and GSP8). Four distinct sites representing the PA4 community subtype are located in the western portion of Wagner Natural Area (Map 1, polygon \#37, \#40, \#41 and \#70).

\subsubsection{Mixedwood communities:}

\section{Sw-Pb/dewberry (SP1)}

White spruce and balsam poplar dominate the tree stratum in this community with the occasional presence of Alaska birch and black spruce (Picea mariana) (Plate 4). Dewberry dominates the shrub layer accompanied by other shrub species such as common Labrador tea, bracted honeysuckle (Lonicera involucrata), prickly rose (Rosa acicularis) and several species of currant. Dominant forb species include twin-flower, bishop's cap, tall lungwort and wild sarsaparilla. Hair-like sedge, two- 

seeded sedge and several other sedge species occur sporadically. Groundcover consists mainly of leaf litter with the occasional presence of Eurhynchium pulchellum, Plagiomnium cuspidatum, or Brachythecium moss species. Soils in the area are subhygric with permesotrophic nutrient regime. The water table was located at about $70 \mathrm{~cm}$ below the soil surface. Carbonates were generally found near the soil surface. Carbonated peaty Orthic Humic Gleysols, carbonated Terric Humisols, and carbonated Terric Mesisols (soil unit RVN1, GSP3, and GSP2) are the dominant soils supporting this community type. Carbonated Rego Gleysols and carbonated Terric Mesic Humisols occupy smaller areas (soil units WNR2 and GSP4). The SP1 vegetation community subtype occurs as scattered patches within the central and eastern portion of the study area (Map 1, polygon \#16, \#27, \#45, \#58, \#66, \#68, \#80 and \#90).

\section{$\underline{\mathrm{Sw}-\mathrm{Pb} / \text { willow-dogwood (SP2) }}$}

An open canopy of white spruce and balsam poplar, intermixed with Alaska birch and river alder (Alnus tenuifolia) characterizes this community. The dense shrub layer consists mainly of various willow species, red-osier dogwood, and numerous Rubus and Ribes species. Common nettle, marsh marigold, and marsh horsetail (Equisetum palustre) are some of the common forbs, while dominant grass species include bluejoint, reed canary grass (Phalaris arundinacea), fowl bluegrass (Poa palustris) and fowl manna grass. Mosses include species of Plagiomnium, Brachythecium, and Drepanocladus. Hygric to subhydric moisture conditions and permesotrophic nutrient regimes characterize the soils within the area. Carbonated Terric Mesisols, carbonated Terric Humisols and carbonated Terric Mesic Humisols (soil units GSP4 and GSP3) are the three dominant soils supporting this community. The water table was located at about $20 \mathrm{~cm}$ below the soil surface. Carbonates were also found near the soil surface. Three small units representing the SP2 community subtype were mapped within Wagner Natural Area (Map 1, polygon \#39, \#82 and \#94).

\section{$\underline{\mathrm{Sw}-\mathrm{Pb} / \text { bunchberry/horsetail (SP3) }}$}

A shrub layer dominated by bunchberry and an extensive cover of common horsetail in the herb layer distinguishes this community subtype from the SP1 subtype. Plagiomnium cuspidatum and Ptilium 

crista-castrensis dominate the well-developed moss layer. Soils were carbonated peaty Orthic Humic Gleysols (soil unit RVN1), typically with hygric moisture conditions and permesotrophic nutrient regimes. A soil pit showed the depth of the water table at about $30 \mathrm{~cm}$, and location of carbonates near the soil surface. The SP3 community subtype occupies one small area in the central portion of the study area (Map 1, polygon \#28).

\section{$\underline{\mathrm{Sw}-\mathrm{Pb} / \text { clover (SP4) }}$}

An unusually high diversity of plant species in the herb layer and a dominance of white clover (Trifolium repens) distinguish this community from the SP1 subtype. The shrub layer consists primarily of Canada buffaloberry (Shepherdia canadensis) and bracted honeysuckle. Thuidium recognitum, Pleurozium schreberi, and Tomenthypnum nitens provide significant ground cover. Subhygric moisture conditions and permesotrophic nutrient regime characterize the soils within the area. The water table was found at about $60 \mathrm{~cm}$ below the soil surface. Carbonates were reported near the soil surface. Soils were mostly carbonated peaty Orthic Humic Gleysols (soil unit RVN1). The dominance of white clover and the high diversity of plant species in the understory indicate that this vegetation community may have bean subjected to vegetation disturbances in the past. It has already been documented that vegetation disturbances may result in the invasion of non-native species and in the increase of overall species diversity (Vujnovic 1998). Although the SP4 community type may be an aberrant type of some other (SP1 or SP5) community types, we decided to classify it as a separate vegetation type in this study with hope that future monitoring will show whether this will remain as a unique community within the Natural Area or will have to be reclassified as a different community type. The SP4 community subtype is located in one small area in the central portion of the study area (Map 1, polygon \#79).

\section{$\underline{\mathrm{Sw}-\mathrm{Pb} / \mathrm{moss}(\mathrm{SP} 5)}$}

This community subtype differs from the SP1 subtype by having more Alaska birch, a sparse shrub and herb layer, and a significant cover of numerous moss species including Aulacomnium palustre, Thuidium recognitum, and Hypnum lindbergii. Soils are carbonated peaty Orthic Humic Gleysols (soil unit RVN1) and are subhygric with a permesotrophic nutrient regime. Both water table and carbonates 

were recorded at a depth of $20 \mathrm{~cm}$. This community subtype is restricted to one small area in the central portion of the study area (Map 1, polygon \#26).

\subsubsection{Coniferous Communities:}

\section{$\underline{\mathrm{Sb}-\mathrm{Lt} / \mathrm{labrador} \text { tea/feather moss (SL1) }}$}

This community is dominated by black spruce, with scattered tamarack (Larix laricina) (Plate 5). Common Labrador tea dominates the shrub layer, while bracted honeysuckle and dewberry occur only sporadically in small patches. Twin-flower, round-leaved orchid, and three-leaved Solomon's-seal are frequent forbs, while bristle-stalked sedge represents one of the few sedge species occurring within this community. Pleurozium schreberi, Hylocomium splendens, and to a lesser extent, Ptilium cristacastrensis dominate the well-developed moss layer. Small hummocks dominated by Sphagnum mosses (mainly Sphagnum fuscum and S. capillifolium), Polytrichum strictum and shrubs species such as crowberry (Empetrum nigrum), bog cranberry (Vaccinium vitis-idaea L. ssp. minus), and small bog cranberry (Oxycoccus microcarpus) occur sporadically within the subtype. Hygric to subhydric moisture conditions and permesotrophic nutrient regime characterize the soils within the area. Soils supporting this community include carbonated Terric Mesisols, carbonated Terric Humisols, Typic Humisols, carbonated Terric Mesic Humisols, and carbonated Rego Gleysols (soil units GSP7, GSP3, GSP4, WNR1, WNR2). The water table was generally found at less then $15 \mathrm{~cm}$ below the soil surface. Carbonates were predominantly recorded at a depth of less than $30 \mathrm{~cm}$ from the soil surface. The SL1 subtype is the predominant vegetation community subtype covering more than $30 \%$ of Wagner Natural Area (Map 1).

\section{$\underline{\mathrm{Sb}-\mathrm{Lt} / \text { labrador tea/feather moss-peat moss (SL2) }}$}

This community differs from the SL1 subtype by having a much higher cover of Sphagnum-dominated hummocks (ca. 30\%). Soils found in the area were carbonated Terric Mesic Humisols (soil unit GSP4) that are characterized by hygric moisture conditions and a permesotrophic nutrient regime. The water table and carbonates were found near the soil surface. Only one polygon represents this community (Map 1, polygon \#33). 



\section{$\underline{\mathrm{Sw}-\mathrm{Sb} / \text { dewberry/sedge/feather moss (SS1) }}$}

White and black spruce co-dominate this community which has also sporadic occurrences of tamarack and Alaska birch (Plate 6). The shrub layer, which never reaches high cover, includes species such as twin-flower, common Labrador tea, dewberry, and bracted honeysuckle. The diverse forb layer includes bishop's cap, three-leaved Solomon's-seal, and wild sarsaparilla, while bristle-stalked sedge, northern bog sedge (Carex gynocrates), and hair-like sedge represent some of the sedge species frequently found in the area. Common horsetail and bristle-stalked sedge sporadically dominate the herb layer. Feather mosses dominate the well-developed moss layer. Subhygric to hygric moisture conditions and a permesotrophic nutrient regime characterize the soils within the area. The water table was generally located at about $15 \mathrm{~cm}$ below the soil surface. Carbonates were found in a range from 5 to $70 \mathrm{~cm}$ below the soil surface. Soils supporting this community included carbonated Terric Mesisols, carbonated Terric Humisols, and carbonated Terric Mesic Humisols, with minor occurrences of carbonated Rego Gleysols, carbonated peaty Orthic Humic Gleysols and carbonated Gleyed Dark Gray Luvisols (soil units GSP3, GSP4, WNR2, CVL2, RVN1). The SS1 community subtype occurs as isolated patches throughout the study area (Map 1, polygon \#20, \#24, \#29, \#31, \#36, \#44, \#67, \#72, \#78, \#81 and \#92)

\section{$\underline{\mathrm{Sw}-\mathrm{Sb} / \text { horsetail (SS2) }}$}

Extensive areas occupied by common, and to a lesser extent by meadow horsetail (Equisetum pratense), as well as a low abundance of feather mosses in the moss layer distinguish this community from the SS1 subtype. Tomenthypnum nitens or Plagiomnium cuspidatum occasionally dominate the moss layer. Soils in the area are subhydric to hygric with mesotrophic to permesotrophic nutrient regimes. Carbonated Terric Mesisols and carbonated Terric Humisols (soil unit GSP3) are the two soil subgroups most commonly found within this community. The water table and carbonates are found at less then $10 \mathrm{~cm}$ below the soil surface.. The SS2 subtype is restricted to two areas located within the central portion of the study area (Map 1, polygon \#30 and \#51) 

Sw/bunchberry/feather moss (SW)

White spruce dominates the tree layer in this community with a sporadic occurrence of balsam poplar, aspen and Alaska birch (Plate 11). Bunchberry frequently dominates the well-developed shrub layer in association with dewberry, bracted honeysuckle and willows such as beaked willow, pussy willow (Salix discolor), and myrtle-leaved willow (Salix myrtillifolia). Dominant species in the herb layer include wild sarsaparilla, and wild strawberry, with frequent occurrence of palmate-leaved coltsfoot, kidney-leaved violet (Viola renifolia), and tall lungwort. Grasses and sedges are rare and include bluejoint, bristle-stalked sedge, hair-like sedge, and Dewey's sedge. Feather mosses provide extensive ground cover. Mesic to subhygric moisture conditions and mesotrophic to permesotrophic nutrient regimes characterize the soils occupied by this community. The water table was generally located more than 1.5 meters below the soil surface and carbonates were found close to the soil surface in most of the soil pits. Carbonated Rego Gleysols and carbonated Gleyed Dark Gray Luvisols are the dominant soils, with minor occurrences of carbonated Terric Mesisols, and carbonated Terric Humisols (soil units WNR2, CVL2, GSP3, GSP1). White spruce forests are scattered within the eastern portion of the study area (Map 1, polygon \#10,\#13, \#52, \#55, \#57, \#63 and \#64).

\subsubsection{Shrubland Communities:}

\section{Willow/sedge-bluejoint (WS)}

This community is dominated by species such as beaked willow, pussy willow, and velvet-fruited willow (Salix maccalliana) (Plate 9). Other shrub species include red-osier dogwood, wild red raspberry and northern gooseberry (Ribes oxyacanthoides). Water sedge (Carex aquatilis), awned sedge and bluejoint dominate the herb layer accompanied by numerous forbs such as marsh marigold, touchme-not, common skullcap (Scutellaria galericulata), and wild mint (Mentha arvensis). Plagiomnium cuspidatum and Drepanocladus aduncus dominate the moss layer when present, but not in a close association. Soils in the area are hygric to hydric with permesotrophic nutrient regimes. Carbonated Typic Mesisols (soil unit GSP8) are the only soils described within this vegetation community. Water 

table and carbonates were generally found near or at the soil surface. The WS community subtype is restricted to the northwestern portion of Wagner Natural Area (Map 1, polygon \#97).

\subsubsection{Wetland Communities:}

\section{Bulrush-sedge/moss fen (FE1)}

Bulrushes, sedges and mosses dominate this community. Generally, there are few trees and total shrub cover is less then $20 \%$. This fen community subtype is a mosaic of shallow water areas (marl ponds), slightly raised areas mainly supporting moss and herb species, and small hummocks inhabited by shrub and stunted tree species with associated moss and forb vegetation. Great bulrush (Scirpus acutus), flatleaved bladderwort (Utricularia intermedia), and Chara algae inhabit shallow marl ponds. Dominant bulrushes and sedges of the raised areas include tufted bulrush (Scirpus cespitosus L. var. callosus), three-square bulrush (Scirpus pungens Vahl ssp. pungens), mud sedge (Carex limosa), livid sedge (Carex livida), green sedge (Carex viridula) and prairie sedge (Carex prairea). Common forbs include seaside arrow-grass (Triglochin maritima), saline shooting-star (Dodecatheon pulchellum), marsh aster (Aster borealis), northern grass-of-Parnassus (Parnassia palustris L. var. neogaea), and common butterwort (Pinguicula vulgaris). Oblong-leaved sundew, which is considered rare in Alberta, is locally abundant, while the provincially more common species, round-leaved sundew, occurs more sporadically and in association with sparse Sphagnum dominated hummocks. Dominant mosses include Scorpidium scorpioides (generally inhabiting edges of marl ponds), followed by Drepanocladus revolvens and Campylium stellatum in somewhat drier areas, and Tomenthypnum nitens in the driest microsites. Sphagnum warnstorfii is the dominant Sphagnum species. Dwarf birch (Betula pumila L. var. glandulifera), dwarf raspberry (Rubus arcticus L. ssp. acaulis), Athabasca willow (Salix athabascensis), hoary willow (Salix candida) and bog rosemary (Andromeda polifolia) dominate the sparse shrub layer with sporadic occurrences of stunted black spruce and tamarack. Carbonated Rego Gleysols (soil unit WNR1) are the dominant soils characterizing this community. Moisture conditions are generally subhydric to hydric with a eutrophic nutrient regime. The water table and carbonates were recorded at or near the soil surface. The bulrush-sedge/moss fen community is located in the central portion of the study area (Map 1, polygon \#48). 



\section{Dwarf birch/sedge/moss fen (FE2)}

This community differs from FE1 by having a higher proportion of shrub cover, including stunted black spruce and tamarack, but the overall species composition is very similar to FE1 (Plate 7). Frequent forb species associated with these shrub dominated areas include Labrador bedstraw (Galium labradoricum), northern green bog orchid, wild lily-of-the-valley (Maianthemum canadense Desf. var. interius), bog violet (Viola nephrophylla), and western wood lily (Lilium philadelphicum L. var andinum). Elephant's-head (Pedicularis groenlandica) (Plate 14) grows mostly in the transitional areas between FE2 and black spruce-tamarack/Labrador tea/feather moss communities. Soils are generally the same as within the FE1 community, with some areas having a permesotrophic nutrient regime. The water table and carbonates were found at or near the soil surface. The FE2 subtype occurs within the central and eastern portions of Wagner Natural Area (Map 1, polygon \#7, \#18, \#23, \#32, \#84, and \#88).

\section{Lt-Sb/dwarf birch-willow/sedge/moss fen (FE3)}

Significant cover of tamarack and black spruce in the tree layer $(>10 \%)$ represents the main difference between this community subtype and the two previous wetland types. Prairie sedge and inland sedge (Carex interior) are the dominant sedge species. Moss hummocks, dominated by Sphagnum capillifolium and S. fuscum and associated vascular plant species (bog rosemary, small bog cranberry, common Labrador tea), are also more common than in the FE1 subtype. Carbonated Rego Gleysols (soil unit WNR1) are the dominant soils characterizing the FE3 subtype, with minor occurrence of carbonated Terric Mesic Humisols (GSP4). Soil moisture conditions are hygric to hydric with a permesotrophic to eutrophic nutrient regime. The water table and carbonates were recorded at or near

the soil surface. This treed fen community is restricted to three small areas located in the central and southeastern portions of the study area (Map 1, polygon \#5, \#11 and \#86) 



\subsubsection{Miscellaneous Cover Types:}

\section{Abandoned field (AF)}

One of the previously cleared fields has not been hayed for some time and contains a number of native species in addition to a number of exotic species described for the HF type below. Native species include common wild rose, false mountain willow, Canada goldenrod (Solidago canadensis), and common yarrow (Achillea millefolium L. ssp. lanulosa). Soils in this type have subxeric to submesic moisture conditions with mesotrophic to permesotrophic nutrient regimes. Dark Gray Luvisols (soil unit BRK1) are the dominant soils. This field is located in the northwestern part of the study area (Map 1, polygon \#95).

\section{Hay field (HF)}

Three hay fields within Wagner Natural Area have been cleared in the past and seeded into exotic grasses and forbs. These fields are harvested annually. Dominant grasses include Kentucky bluegrass (Poa pratensis), red fescue (Festuca rubra), awnless brome (Bromus inermis Leyss.ssp. inermis), and timothy (Phleum pratense). Alfalfa (Medicago sativa), alsike clover (Trifolium hybridum) and red clover (Trifolium pratense) dominate sporadically. Wild vetch (Vicia americana) is one of the few native plants found in these fields. Soils are Dark Gray Luvisols, carbonated Gleyed Dark Gray Luvisols and Calcareous Dark Gray Chernozems (soil units CVL1, CVL2, CVL3), characterized by submesic to subhygric moisture conditions and a mesotrophic nutrient regime. The hay fields are located in the western and northeastern portion of Wagner Natural Area (Map 1, polygon \#75, \#77, and \#99).

\section{Beaver pond and associated flooding area $(\mathrm{BE})$}

Two beaver ponds exist within Wagner Natural Area. The larger pond is located along the western edge of the area and floods the dugout described for this area in previous reports (WNAS and AEP 1999). The beaver dam in the eastern portion of Wagner Natural Area is partially broken and vegetation is 

starting to occupy previously flooded ground. Canada thistle (Cirsium arvense), smooth perennial sowthistle (Sonchus uliginosus), common cattail (Typha latifolia), Philadelphia fleabane (Erigeron philadelphicus), bluejoint, wild mint, and various sedge and willow species are some of the plants that occur in this area. Soils in the area were carbonated Terric Mesisols (soil units GSP1 and ZWA2). See Map 1 (polygon \#15 and \#74) for the location of the two beaver ponds.

\section{Clearing (CL)}

Small portions of the area have been continually disturbed as road allowances and road right-of-ways. These areas occur only within the eastern portion of the Natural Area (Map 1, polygon \#3, \#8, \#12, and \#76). Typic Humisols, carbonated Terric Mesisols, and carbonated Rego Gleysols (soil units GSP7, GSP1, WNR1, WNR2) are the dominant soils found in the cleared areas.

\section{Marl pond (MP)}

One large pond (Jones's Pond) and numerous small ponds (in the fen community) are occupied by shallow water overlaying marl deposits (Map 1, polygon \#4, \#35, \#50, \#69, \#85, \#89 and \#91). Flatleaved bladderwort inhabits small ponds and edges of Jones's Pond, while algae such as Chara and numerous diatoms (Alice Hendry, personal communication) inhabit open water areas.

\subsubsection{Cluster Analysis of Vegetation Communities:}

The TWINSPAN analysis generally agreed with the classification that was based on aerial photo interpretation and related plot data. It revealed 11 meaningful vegetation groups within the first five division levels. Each group was assigned a unique letter (a-k) to assist the viewing of the TWINSPAN two-way table (Table 3). Division 1 strongly separated agricultural fields (j-k) from the rest of the native plant communities (Eigenvalue $=0.7716$ ). The fen community type $(\mathrm{a}-\mathrm{b})$ separated from the rest of the native plant communities in the second division (Eigenvalue $=0.6224)$. Division 3 separated the abandoned field $(\mathrm{k})$ from the other three fields $(\mathrm{j})$ that have been hayed annually (Eigenvalue $=$ 0.4199). The Lt-Sb/dwarf birch-willow/sedge/moss fen (b) separated from the other two fen 

Table 3*. TWINSPAN classification of 90 plots and 256 vascular and non-vascular plant species in Wagner Natural Area. Plot numbers (1-90) and plot groups (a-k) are listed across the top of the table, while species seven letter codes and species groups (A-G) are listed on the left hand side.

* Because of its large size, Table 3 was placed in the map pocket at the back of the report 

community subtypes $(\mathrm{a})$ in division 4 (Eigenvalue $=0.3735$ ). Division 5 isolated deciduous and shrubland community types (g-i) from mixedwood (e) and coniferous (c-d) community types (Eigenvalue $=0.5604)$. The white spruce-balsam poplar community type $(\mathrm{e})$ was set apart from coniferous communities $(\mathrm{c}-\mathrm{d})$ in division 10 (Eigenvalue $=0.4016)$. Division 11 separated the willow/sedge-bluejoint community (g) from the balsam poplar-aspen community type (h-i) (Eigenvalue $=0.4180)$. Black spruce-tamarack forests (c) were separated somewhat weakly from the white spruceblack spruce forests $(d)$, in division $20($ Eigenvalue $=0.2346)$. Division 21 sets the white spruce-balsam poplar/clover forest (f) apart from the rest of the white spruce-balsam poplar community subtypes (e) $($ Eigenvalue $=0.2859)$. Finally, at division 46 , the balsam poplar-aspen $/ \mathrm{marsh}$ reed grass $/ \mathrm{sedge}$ community subtype (h) separated from the rest of the balsam poplar-aspen community subtypes (i) $($ Eigenvalue $=0.3472)$.

TWINSPAN failed to separate out Alaska birch-balsam poplar and white spruce forests from mixed white spruce-balsam poplar vegetation community types.

As opposed to relatively high statistical significance observed in plot divisions, the species groups derived by TWINSPAN showed generally low Eigenvalues. However, seven main species groups could still be identified. In Table 3, those species groups are labeled with capital letters A-G. The majority of species in group A are restricted to the fen community type. Species in group B characterize the willow/sedge-bluejoint community. Group C species dominate the balsam poplar-aspen community type, but are also found frequently in the mixed white spruce-balsam poplar community type. Species in group D characterize the white spruce-balsam poplar community type, although a number of them inhabit mixed white spruce-black spruce and black spruce-tamarack communities as well. Group E species dominate both black spruce-tamarack and white spruce-black spruce community types, which explains the somewhat low statistical significance of separation between these two vegetation community types. Finally, $\mathrm{F}$ and $\mathrm{G}$ species groups defined agricultural fields, with $\mathrm{G}$ clearly dominating the present hay fields, and F distinguishing the abandoned field.

Unweighted Arithmetical Average Clustering (UPGMA) produced similar results to TWINSPAN clustering. Once again, classification of the 90 plots reflected the wide distribution of the majority of plant species that make up plant communities in Wagner Natural Area. An objective cut at 7.05E+00 

(Bray-Curtis Distance) revealed 17 plot groups (Figure 2). They were further subjectively organized into eight meaningful groups (community types/subtypes) by combining back some of the groups that were not supported by the field observations. On Figure 2 eight plot groups are labeled A-H (misclassified groups are labeled X). Group A represents a willow/sedge-bluejoint vegetation community. The balsam poplar-aspen community (B) is the most similar to the white spruce-balsam poplar community (C). Plots in group D belong to the black spruce-tamarack community type and are the most similar to group $\mathrm{E}$ which represents a mixture of white spruce and white spruce-black spruce community types. Two plots representing Lt-Sb/dwarf birch-willow/sedge/moss fen are labeled as $\mathrm{F}$ on the graph, while $\mathrm{G}$ represents the other two fen communities. Finally, group $\mathrm{H}$ represents the agricultural fields, including the abandoned one. Similar to the TWINSPAN analysis, UPGMA failed to clearly separate some of the plant communities that were recognized based on air photo interpretation and related plot data. UPGMA placed plots sampled within the Alaska birch-balsam poplar community together with plots from other mixed communities (balsam poplar-aspen and white spruce-balsam poplar). Some of the plots representing white spruce-black spruce forests were placed within the balsam poplar-aspen and white spruce-balsam poplar plot groups, and some were mixed with the plots from the white spruce community. Overall, TWINSPAN provided better separation of the observed and mapped plant communities within Wagner Natural Area than did the UPGMA analysis.

Narrow ranges of moisture conditions (subhygric to subhydric) and nutrient regimes (mesotrophic to permesotrophic) characterizing many community types and subtypes within Wagner Natural Area may explain the difficulties in separating different community types using TWINSPAN and UPGMA cluster analyses. The best clustering of vegetation communities is generally obtained when there is a clear gradient in one or a few environmental variables (e.g. moisture, elevation) governing plant species distribution within a study area (Kent and Coker 1992). Zoltai and Johnson (1987) reported high vegetation sensitivity to relatively small nutrient fluctuation at low nutrient levels (oligotrophic and submesotrophic). In contrast, they found that as the concentration of nutrients increased, only much higher changes in nutrient levels influence differences in the distribution of plant species. This may 

Figure 2. Eight plot groups (A - H) derived by the Unweighted Arithmetical Average Clustering (UPGMA) of 90 plots and 256 vascular and non-vascular plant species in Wagner Natural Area. Misclassified groups are labeled $\mathbf{X}$. An objective cut was made at Bray-Curtis Distance of 7.05E+00. 


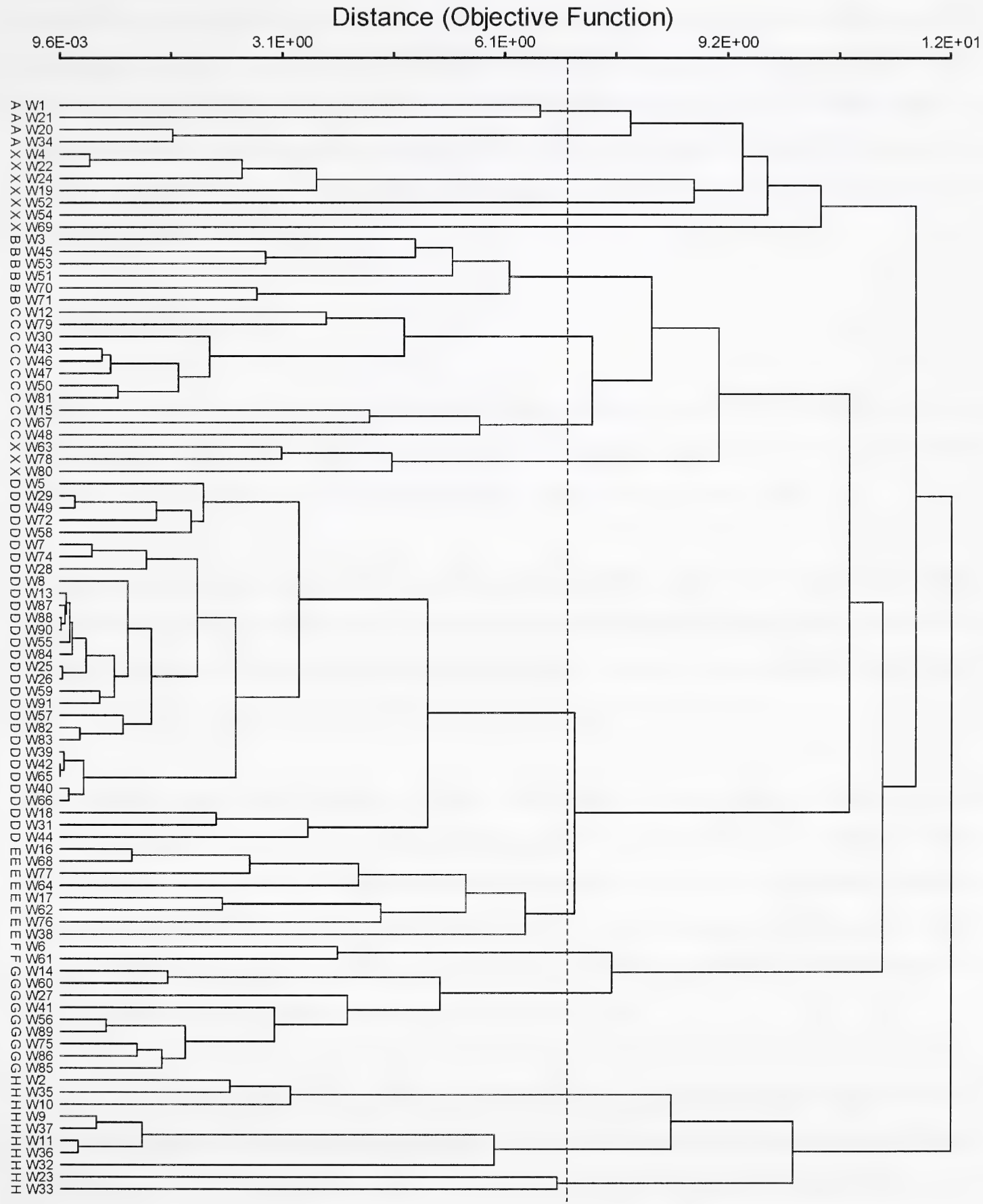



explain why many of the same plant species occur in a variety of vegetation communities within Wagner Natural Area (Table 3). In addition, when describing plant communities, an effort is usually made to sample only representative areas of the vegetation communities and to avoid areas where adjacent communities blend into each other (ecotones) ( Braun-Blanquet 1965). Unfortunately, the fairly restricted grid sampling system applied in this study, and the large number of plots sampled in a relatively small area, most likely resulted in the sampling of some areas that represented ecotones between vegetation communities.

\subsection{Rare Plant Occurrences}

Of the 7 rare vascular plant species recorded for Wagner Natural Area, two (white adder's mouth and oblong-leaved sundew) were found in this study. Of the 7 rare moss species known to occur in Wagner Natural Area, one (Brachythecium campestre) was located within our study plots.

Brachythecium campestre was found once during this study (Map 1, plot \#47) in the balsam poplaraspen/dewberry forest. This species has been reported previously from the northcentral portion of the Wagner Natural Area (J.Rintoul, personal communication). Brachythecium campestre sporadically occurs on tree bases, logs, and on mineral soil in mixedwood forests in Alberta.

White adder's mouth was recorded in three field plots located within the black sprucetamarack/Labrador tea/feather moss subtype (Map 1, plot \#18, \#57 and \#90); once within the white spruce-black spruce/dewberry/sedge/feather moss subtype (plot \#72); and in one plot sampled in the white spruce-balsam poplar/clover subtype (Map 1, plot \#12). Previous reports of this species for the Wagner Natural Area do not specify its precise location (J. Rintoul, personal communication). The species occurred as an individual plant in most cases (Plate 12).

Oblong-leaved sundew was found in 4 sample plots within the shrub fen community (Plot \#14, \#85, \#86, and \#89) (Plate 8). This species grows in nutrient rich fen habitats and is more common in Wagner Natural Area than the round-leaved sundew (Drosera rotundifolia) which more commonly occurs on 

sites dominated by Sphagnum mosses. Previous reports of oblong-leaved sundew in the Wagner Natural Area do not specify its precise location (J. Rintoul, personal communication).

\subsection{Other Plant Occurrences}

Many of the plant species recorded for Wagner Natural Area are typical of peatlands with calcareous (carbonated) soils and high water tables, which are common within the adjacent Boreal Forest Natural Region (Achuff 1994) but occur uncommonly within the Central Parkland Sub-region. In addition to the large number of representatives of the Cyperaceae family (e.g. 27 species of sedges), 16 orchid and 6 carnivorous plant species also occur (McIsaac and Macdonald n.d.). All orchid and carnivorous plant species recorded during the field data collection, with their locations as indicated on Map 1, are discussed in the following section:

\subsubsection{Orchids}

Wagner Natural Area is known for its orchid populations. Although at least 16 different species of orchids reside within the Natural Area (Hrapko 1991), only those species recorded during the field sampling are listed below:

Cypripedium calceolus (yellow lady's -slipper) was found in sample plots within white spruce-balsam poplar, white spruce-black-spruce, and black spruce-tamarack community types (Plot \#12, \#28, \#30, $\# 31, \# 38, \# 64, \# 66, \# 77, \# 79$, \#90, and \#91). In sample plot \#30 (white spruce-balsam poplar/dewberry forest) the species covered approximately $10 \%$ of the area, whereas in other plots it was generally represented by approximately 10 to 20 individual plants.

Goodyera repens (dwarf rattlesnake plantain) was found only once, at the SW corner of permanent plot \#16, in the white spruce forest. Each of the two flowering individuals were about $10 \mathrm{~cm}$ tall (Plate 13). Although widespread within the Dry Mixedwood Sub-region, this species is uncommon in the Central Parkland Sub-Region (Moss 1983) and it has been reported only once before for Wagner Natural Area. 

The precise location of the first observation is not known, but is reported to have been found in approximately the same area as reported this year (P. Cotterill, personal communication).

Habenaria dilatata (tall white bog orchid) was found only once, in plot no. 75 , within the dwarf birch/sedge/moss fen community.

Habenaria hyperborea (northern green bog orchid) was found scattered within the black sprucetamarack forest and fen areas. It usually occurs as individual plants or in small groups (Plot \#5, \#6, \#12, $\# 18$, \#27, \#28, \#44, \#48, \#55, \#56, \#66, \#72, \#75 and \#90).

Habenaria obtusata (blunt-leaved bog orchid) was found as individual plants in only four plots within the white spruce-black spruce and white spruce-balsam poplar forests, and in the open fen area (Plot \# 58, \#60, \#77 and \#79).

Listera cordata (heart-leaved twayblade ) was found in 8 plots, mainly in the black spruce-tamarack forest community (Plot \# 7,\#13,\#57, \#83, \#84, \#88, \#90 and \#91). It usually occurs in groups of 10 to 30 individuals, but because of its small size it covers only small areas on mossy ground.

Orchis rotundifolia (round-leaved orchid) is the most common orchid species within Wagner Natural Area. It was reported within 29 sampling plots where it frequently covered up to $3 \%$ of the plot area.

\subsubsection{Carnivorous Plants}

Carnivorous plants are another interesting group of plant species inhabiting the Natural Area. These species thrive in calcium rich fens because of their ability to supplement nitrogen and phosphorus (elements with generally low concentrations in calcium rich soils) obtained from animal tissues (Vitt, 1982). The previously mentioned oblong-leaved sundew is one of the six carnivorous species listed for Wagner Natural Area (McIsaac and Macdonald n.d.). 

Drosera rotundifolia (round-leaved sundew) was found only twice during the field data collection (plot $\# 6$ and \#61), both times covering small areas within the tree dominated fen areas. Although generally more widespread within the province than the related species D. anglica (Moss 1983), round-leaved sundew tolerates ombrotrophic nutrient conditions and is therefore restricted to the top of Sphagnum hummocks within this nutrient-rich wetland area.

Pinguicula vulgaris (common butterwort) was recorded four times, in the fen vegetation community (plot \# 27, \#41, \#61 and \#86).

Utricularia intermedia (flat-leaved bladderwort) is the only aquatic carnivorous plant recorded during the field sampling. It inhabits shallow marl ponds within the fen community (plot \#14, \#41, \#56, \#60 and \#89).

\subsection{Correlation Between Native Vegetation Communities Described in Wagner Natural Area and Communities Listed in the Relevant Literature}

The correlation between native plant communities described in this study and related communities described in the relevant literature is shown in Table 4. Beckingham and Archibald (1996) and Willoughby et al. (1997) described numerous vegetation communities similar to those found in Wagner Natural Area. However, very few names of the previously described communities could be used directly to describe communities in Wagner Natural Area because of differences in plant species composition and related environmental conditions. There are several possible explanations for these differences. First, the scale at which the vegetation communities have been described and mapped in Wagner Natural Area in this study is more detailed than that used to describe communities in the Northern Alberta studies (Beckingham and Archibald 1996; Willoughby et al. 1997). Second, unique environmental conditions characterizing Wagner Natural Area, such as unusually high concentrations of carbonates in the soils, combined with the high soil moisture, may have allowed species or species combinations different from those found in the northern portion of the province to predominate in the communities of Wagner Natural Area. 



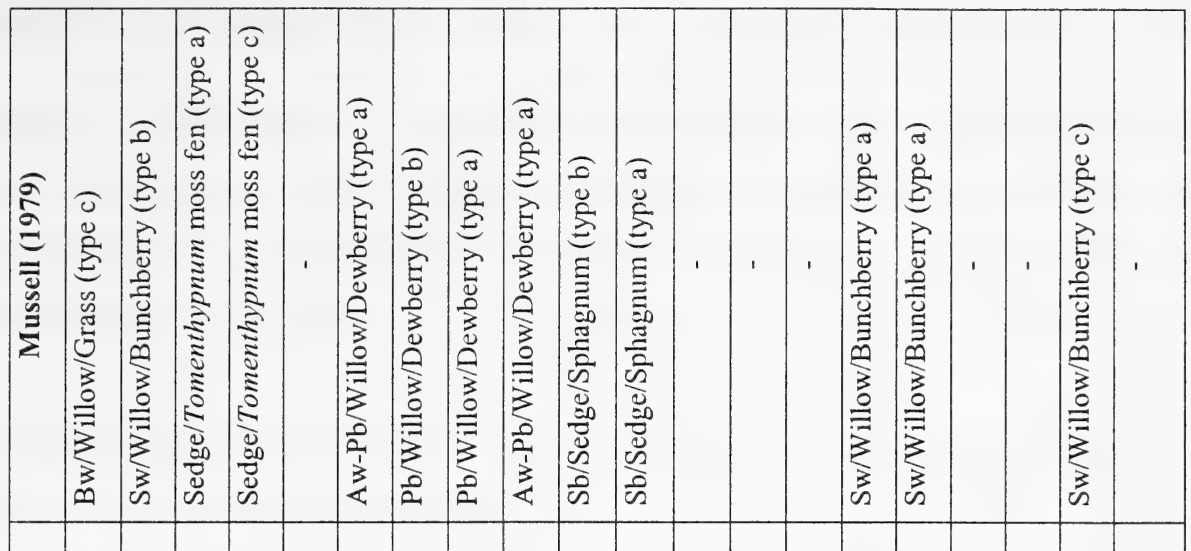

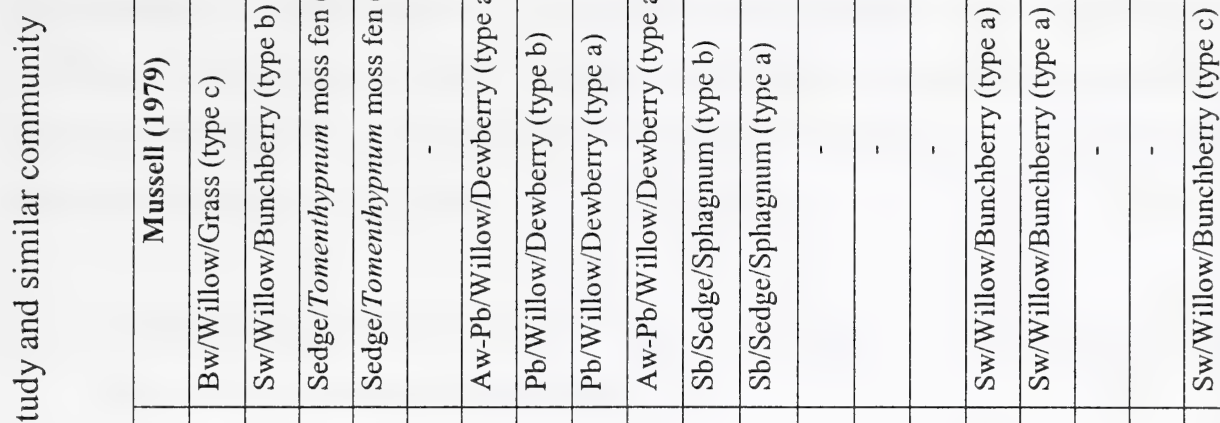

ᄋ

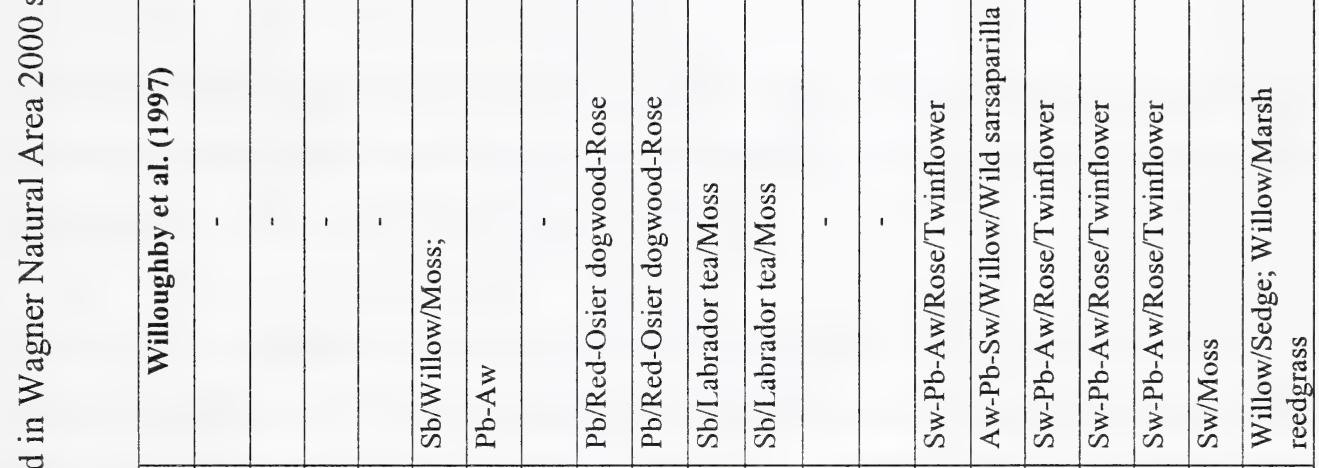

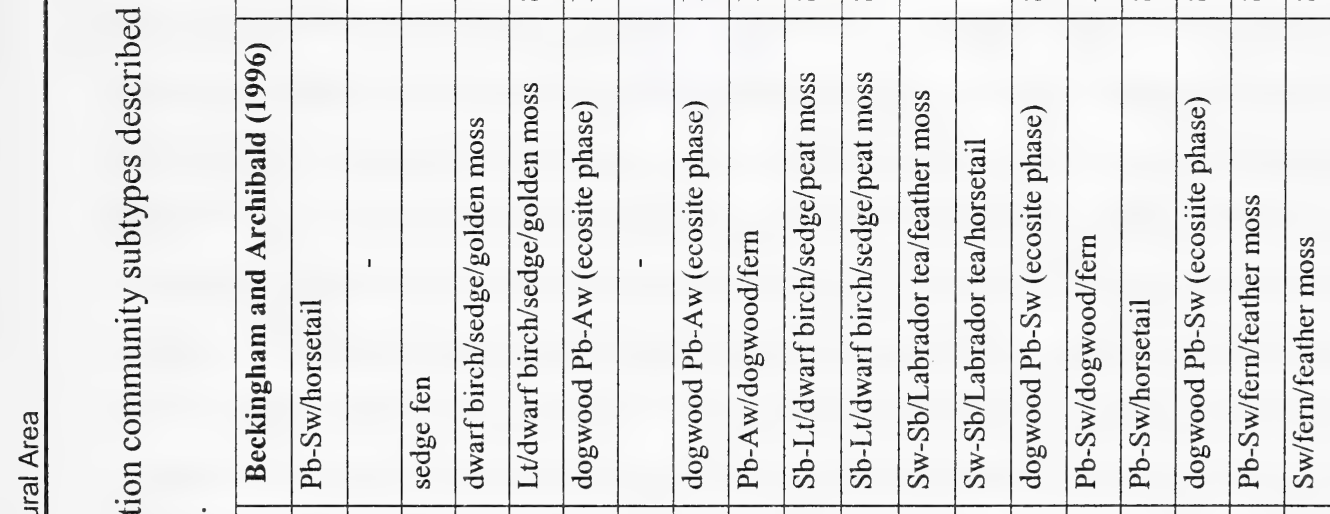



The differences between vegetation communities described in this study and those previously described for Wagner Natural Area (Mussell 1979) are probably the result of differing sampling intensities and methods. However, the lack of a description of the methodology used in Mussell's (1979) study does not allow resolution of this matter.

\subsection{Relationships Between Native Vegetation Communities in Wagner Natural Area and Local Environmental Conditions}

Eight main native vegetation community types with twenty subtypes reflect the complexity of habitat characteristics in Wagner Natural Area and challenged our ability to depict the diversity of vegetation communities at a scale of 1:5,000.

Contrary to our general expectations of finding the majority of 'upland' communities growing on mineral soils (Mussell 1979), we found very few areas with mineral soils, other than those associated with agricultural fields (Map 2, RVN1, and CVL2). General climatic and local environmental conditions (relatively flat surface and high water table) have resulted in the development of peaty soils over much of the natural area. The peat basal layer is estimated to be close to 4700 years old (Johnson, 1982). The ground water in the area is highly minerotrophic (Karlin and Bliss, 1983) and generally high water tables result in moderate to high minerotrophic conditions of the peat. This may explain the existence of vegetation communities such as white spruce-balsam poplar, balsam poplar-aspen, and Alaska birch-balsam poplar on shallow organic soils. In the balsam poplar-aspen/dewberry community, balsam poplar-aspen /dogwood forests, and white spruce forests the water tables were not as high during the field season as those in other vegetation communities. However, the presence of carbonates near the soil surface indicated that, at least during the springtime, water tables are high enough to enrich peat with nutrients sufficient to support these forest communities.

The analyses of soil and vegetation relevé data revealed certain relationships between vegetation communities and local environmental conditions such as soil type, soil moisture regime and soil nutrient regime. Mineral soils found on the agricultural fields occupy the dry end of the moisture gradient. They are also the least minerotrophic of all soils found in the area. The soils found in the three 

fen communities occupy the wettest end of the moisture gradient and are also the most nutrient rich. The three fen community subtypes varied somewhat in soil moisture and nutrient regimes, but all three had very high water tables. The Lt-Sb/dwarf birch-willow/sedge/moss fen had the driest and the least nutrient rich soils of the three fen subtypes while the bulrush-sedge/moss fen had the wettest and the most nutrient rich soils.

Higher water tables (at or near the soil surface) and lower nutrient concentrations in the top $30 \mathrm{~cm}$ of the peat distinguishes the soils supporting the black spruce-tamarack/Labrador tea/feather moss forest from those found in other community types. The lack of extensive areas dominated by Sphagnum species such as Sphagnum fuscum and the significant cover of tamarack show generally minerotrophic conditions governing plant species composition within this vegetation community. Black spruce is known to grow well in a broad range of peatland types while tamarack prefers strongly to moderately minerotrophic soil conditions (Karlin and Bliss, 1983). The extensive cover of feather mosses and the significant presence of other moss species such as Tomenthypnum nitens, Aulacomnium palustre and Dicranum undulatum are also indicators of weakly to moderately minerotrophic soil conditions (Karlin and Bliss, 1983). Although Sphagnum hummocks are not abundant within the black sprucetamarack/Labrador tea/feather moss forest, their presence indicates local ombrotrophic substrate conditions. Shallowly rooted species such as common Labrador tea, crowberry, and small bog cranberry are well adapted to the low nutrient status characterizing these hummocks. Karlin and Bliss (1983) suggest that minerotrophic peatlands with localized ombrotrophic environmental conditions such as those occurring in the Natural Area, should be called 'mixed mire'. The considerably higher proportion of peat moss dominated hummocks in the black spruce-tamarack/Labrador tea/feather moss-peat moss community can not be explained by environmental data collected during this study; however, it is likely related to localized patterns of ground water flow in the area.

Soils found in association with the remaining vegetation community types in Wagner Natural Area are in the middle range of moisture and nutrient regimes. The reasons for the present day distribution of deciduous, mixedwood, and white spruce community types can only be surmised, and more detailed and long term studies on geomorphology, hydrology, soil micronutrient dynamics and the history of disturbances are needed to better understand ecosystem functioning in Wagner Natural Area. 

Disturbances such as fire, beaver activities, and wind-throws (Plate 10), are well known as factors that drive forest succession. Long term climatic cycles such as prolonged periods of drought or cold, in conjunction with microsite environmental conditions, influence the direction of succession and the longevity of each successional (seral) stage (Barbour et al. 1980, Kimmins 1987).

The detailed soil and vegetation inventory, and establishment of permanent monitoring plots achieved with this study, provide a baseline for future monitoring of soil conditions and the composition and spatial distribution of vegetation communities. Wagner Natural Area receives most of its ground water from the land to the south, hence future monitoring of groundwater hydrology may also be necessary to explain soil and vegetation dynamics within Wagner Natural Area.

\subsection{Application of Inventory to EMAN Biodiversity Monitoring}

The EMAN protocols provide guidance for "monitoring plant diversity change over time in the various strata of those plant communities that make up Canadian terrestrial ecosystems"(Roberts-Pichette and Gillespie 1999). The soil and vegetation inventories completed during this study provide essential information on the present soil and vegetation diversity within the Natural Area. An attempt was made to locate the 18 monitoring (EMAN) plots within the Natural Area in such a way as to document as many identified vegetation communities and soil units as possible. Hay fields were included because they are located on mineral soils within the Natural Area, as well as to provide baseline soil and vegetation data for future monitoring of vegetation succession if hay production is discontinued. Although the long-term monitoring of soil conditions (moisture, nutrients) is not a required component of the EMAN biodiversity monitoring strategy, the soil information collected during this study may provide some insight into vegetation community changes over time. 



\subsection{LITERATURE CITED}

Achuff, P. L. 1994. Natural Regions, Subregions, and Natural History Themes of Alberta - a classification for protected areas management. Report prepared for Park Services, Alberta Environmental Protection, Edmonton, AB.

Alberta Environmental Protection. 1993. Alberta plants and fungi - master species list and species group checklists. Prepared by the Alberta Environmental Protection, Edmonton, AB.

Alberta Land and Forest Service. 1994. Ecological land survey site description manual. Alberta Environmental Protection; Resource Information Division. Edmonton, AB. 150 pp + app.

Alberta Natural Heritage Information Centre (ANHIC). 2000. Elements on the Watch List. http://www.gov.ab.ca/env/parks/anhic/wtchanhi.html

American Ornithologists' Union. 1998. Checklist of North American Birds - $7^{\text {th }}$ edition, Forty-First Supplement to the Check-list - 1997, Auk Vol.114, No. 3; American Ornithologists' Union, Washington, DC

Anderson, L.E., H A. Crum, and W.R. Buck. 1990. List of the mosses of North America north of Mexico. The Bryologist 93: 448-499.

Barbour, M. G., J. H. Burk, and W. D. Pitts. 1980. Terrestrial plant ecology. The Benjamin Cummings Publishing Company, Menlo Park, California, USA.

Beckingham, J.D. and J.H. Archibald. 1996. Field Guide to Ecosites of Northern Alberta. Canadian Forest Service Special Report No.5, Northern Forestry Centre, Edmonton, AB.

Bloom, S.A. 1981. Similarity indices in community studies: potential pitfalls. Marine Ecology Progress Series 5:125-128.

Bowser, W.E., A.A. Kjearsgaard, T.W. Peters and R.E. Wells. 1962. Soil survey of the Edmonton sheet $(83 \mathrm{H})$. Alberta Soil Survey Report No. 21. University of Alberta, Edmonton, Alberta.

Braun-Blanquet, J. 1965. Plant sociology: the study of plant communities. English translation of Pflanzensoziologie revised and edited by G.D. Fuller and H.S. Conard. Hafner Publishing Co., London, England.

Brierley, J.A., B.D. Walker, C.J. Tomas and P.E. Smith. 1998 (unpublished). Alberta soil names file generation 3. Land Resource Unit, Agriculture and Agri-Food Canada, Edmonton, AB.

CAESA Soil Inventory Project Working Group. 1998. AGRASID: Agricultural region of Alberta soil inventory database (Version 1.0). Edited by: J.A. Brierley, B.D. Walker, P.E. Smith, and W.L. Nikiforuk. Alberta Agriculture Food and Rural Development, Publications. CD-ROM. 

Canadian Forest Service and Alberta Land and Forest Service (CFS-LFS). 1994. Ecological land survey site description manual. Canada/Alberta Partnership Agreement in Forestry publications.

Clayton, P. Member of Wagner Natural Area Society; 26519 Highway 16, Spruce Grove, AB, T7X 3L4; (wagnerfen a connect.ab.ca).

Cotterill, P. Member of Wagner Natural Area Society; 26519 Highway 16, Spruce Grove, AB, T7X 3L4; (wagnerfen@ connect.ab.ca).

Crum, H. (in Collaboration with Sandra Planisek). 1988. Peatlands and peat mosses. The University of Michigan press, MI, USA

Environment Canada. 1993. Canadian climate normals 1961-90 - prairie provinces. Canadian Communication Group - Publishing, Ottawa, ON.

Fairbarns, M. 1989. Bog Adder's-mouth orchid (Malaxis paludosa) in Wagner Natural Area Vicinity. Public Lands Division, Alberta Forestry, Lands and Wildlife, Edmonton, AB.

Government of Alberta. 1994. A framework for Alberta's Special Places. Natural regions, Report No. 1. Edmonton, $\mathrm{AB}$.

Hamilton, W.N., M.C. Price and C.W. Langenburg (compilers). 1999. Geological map of Alberta. Alberta Geological Survey, Alberta Energy and Utilities Board, Map No. 236, scale $1: 1,000,000$.

Hendry Alice, Member of Wagner Natural Area Society; 26519 Highway 16, Spruce Grove, AB, T7X 3L4; (wagnerfen@aconnect.ab.ca).

Hill, M. O. 1979. TWINSPAN - A FORTRAN program for arranging multivariate data in an ordered two-way table by classification of the individuals and attributes. Cornell University, Ithaca, New York.

. 1973. Diversity and evenness: a unifying notation and its consequences. Ecology 54:427-432.

Hrapko J.O. 1991. Wagner Natural Area Plant Checklist, Natural History Information No. 88, Alberta Culture and Multiculturalism, Provincial Museum of Alberta, Edmonton.

Johnson, J.D. 1982. Results of preliminary investigation on the peat deposits and vegetation of Wagner Bog. Pages 14-16 in: Special Issue - The Wagner Bog. The Edmonton Naturalist. Vol.10, No. 2, Edmonton Natural History Club, Edmonton, AB

Jongman, R. H. G., C. J. F. ter Braak, and O. F. van Tongeren, editors. 1987. Data analysis in community ecology. Pudoc Wageningen, Netherlands. 

Karlin E.F. and L.C. Bliss. 1983. Variation in substrate chemistry along microtopographic and waterchemistry gradients in peatlands. Canadian Journal of Botany 62: 142-153.

Kent, M., and P. Coker. 1992. Vegetation description and analysis: a practical approach. CRS Press, London, Belhaven Press.

Kimmins, J.P. 1987. Forest ecology. Macmillan Publishing Company, New York, New York.

Legendre, L., and P. Legendre. 1983. Numerical ecology. Elsevier, Amsterdam.

McIsaac P., and C. Macdonald. n.d. Wagner Natural Area plants. Alberta's Watchable Wildlife Checklist Series, Government of Alberta, Edmonton, AB

Moss, E. H. 1983. The flora of Alberta. (2nd edition). Revised by J. G. Packer. University of Toronto Press, Toronto, ON.

MSWG (Mapping Systems Working Group). 1981. A soil mapping system for Canada: revised. Land Resource Research Institute, Contribution No. 142. Agriculture and Agri-Food Canada. Ottawa, ON.

Mueller-Dombois, D., and H. Ellenberg. 1974. Aims and methods of vegetation ecology. Wiley, New York.

Mussell, D. 1979. Resource inventory for proposed Educational Natural Areas: Wagner property. Unpublished Report for Natural Areas Program, Alberta Energy and Natural Resources, Edmonton, $\mathrm{AB}$.

Nesby, R. 1997. Alberta vegetation inventory standards manual: version 2.2. Alberta Environmental Protection. Edmonton, AB.

Prosser, D. 1982. Hydrology of Wagner Bog. Pages 8-13 in: Special Issue - The Wagner Bog. The Edmonton Naturalist. Vol.10, No. 2, Edmonton Natural History Club, Edmonton, AB

Province of Alberta. 1989. Wilderness Areas, Ecological Reserves and Natural Areas Act. Queen's Printer, Edmonton, AB

Rintoul, J.B. Data Coordinator. Alberta Natural Heritage Information Centre, Alberta Environment; $12^{\text {th }}$ floor, Oxbridge Place, 9820-106 Str., Edmonton, AB, T5K 2 J6.

Roberts-Pichette, P., and L. Gillespie. 1999. Terrestrial vegetation biodiversity monitoring protocols. EMAN Occasional Paper Series, Report No. 9. Ecological Monitoring Coordinating Office. Burlington, ON.

Shetsen, I. 1990. Quaternary geology, central Alberta. Alberta Research Council, Edmonton, Alberta. 

Simons, I. and M.G. Willoughby. 1990. Range survey manual: Alberta Forest Service: Range Management Section 3rd edition. Alberta Forestry, Lands and Wildlife; Alberta Forest Service; Forest Land Use Branch. Edmonton, AB.

Soderstrom, L. 1988. Sequence of bryophytes and lichens in relation to substrate variables of decaying coniferous wood in Northern Sweden. Nordic Journal of Botany 8(1): 89-97.

Soil Classification Working Group. 1998. The Canadian system of soil classification: 3rd edition. Agriculture and Agri-Food Canada Publication 1646. NRC Research Press. Ottawa, ON.

Spencer Environmental Management Services. 1990. Environmental assessment for proposed interchange and connector road for junction of highway 16X and secondary highway 794. Volume I Final Environmental assessment. Report prepared for Wagner Study Advisory Group. Edmonton, $\mathrm{AB}$

Thormin, T. 1982a. Orchids of the Wagner Bog. Pages 23-32 in: Special Issue - The Wagner Bog. The Edmonton Naturalist. Vol.10, No. 2, Edmonton Natural History Club, Edmonton, AB

. 1982b. Butterflies of the Wagner Bog. Pages 37-41 in: Special Issue - The Wagner Bog. The Edmonton Naturalist. Vol.10, No. 2, Edmonton Natural History Club, Edmonton, $\mathrm{AB}$

. 1982c. Birds of the Wagner Bog. Pages $42-44$ in: Special Issue - The Wagner Bog. The Edmonton Naturalist. Vol.10, No. 2, Edmonton Natural History Club, Edmonton, AB

Vitt, D.H. 1982. Peatland formation and vegetation of the Wagner Bog. Pages 17-22 in: Special Issue - The Wagner Bog. The Edmonton Naturalist. Vol.10, No. 2, Edmonton Natural History Club, Edmonton, $\mathrm{AB}$

Vujnovic, K. 1998. Small-scale plant species composition and diversity in relation to environmental and disturbance factors in fescue grasslands of the Aspen Parkland of Alberta. M.Sc. thesis, Faculty of Graduate Studies and Research, University of Alberta, Edmonton, AB.

Wagner Natural Area Society. 1988. Mammals of Wagner Natural Area - a field checklist. Compiled by Wagner Natural Area Society, Edmonton, AB.

. 1986. Marl Pond Trail guide. Post 15. Marl Ponds.

and Alberta Environmental Protection. 1999. Wagner Natural Area management plan. Wagner Natural Area Society. Edmonton, AB.

Willoughby, M.G., K. Sundquist, and D. Downing. 1997. Range plant community types and carrying capacity for the Dry and Central Mixedwood Subregions (second approximation). Environmental Protection, Land and Forest Services, Edmonton, AB. 

Zoltai, S.C. and J.D. Johnson. 1987. Relationships between nutrients and vegetation in peatlands of the prairie provinces. In: Rubec, C.D.A. and R.P. Overand. Proceedings Symposium 87, Wetlands/Peatlands, August 23-27, 1987. Edmonton, AB. 



\section{APPENDIX 1 \\ GPS Positions of Detailed Plots in Wagner Natural Area}



Appendix 1. GPS Positions of Detailed Plots in Wagner Natural Area

\begin{tabular}{|c|c|c|c|c|c|c|c|}
\hline $\begin{array}{l}\text { Detailed } \\
\text { plot\# }\end{array}$ & \begin{tabular}{|c|} 
Plot \\
Corner
\end{tabular} & Latitude & Longitude & Easting & Northing & $\begin{array}{l}\text { GPS points } \\
\text { collected }\end{array}$ & $\begin{array}{l}\text { Horizontal precision } \\
\text { differential } \\
\text { correction }(\mathrm{m})\end{array}$ \\
\hline \multirow[t]{4}{*}{1} & SW & $53^{\circ} 34^{\prime} 04.89638$ & $113^{\circ} 50^{\prime} 03.59370$ & 312315.281 & 5939198.0 & 51 & 0.373 \\
\hline & NW & $53^{\circ} 34^{\prime} 05.53296$ & $113^{\circ} 50^{\prime} 03.52657$ & - & - & 50 & 0.393 \\
\hline & $\mathrm{NE}$ & $53^{\circ} 34^{\prime} 05.49658$ & $113^{\circ} 50^{\prime} 02.49705$ & - & - & 51 & 0.270 \\
\hline & SE & $53^{\circ} 34^{\prime} 04.88774$ & $113^{\circ} 50^{\prime} 02.50549$ & - & - & 51 & 0.380 \\
\hline \multirow[t]{4}{*}{2} & SW & $53^{\circ} 34^{\prime} 08.48267$ & $113^{\circ} 50^{\prime} 08.23864$ & 312234.281 & 5939312.5 & 181 & 0.273 \\
\hline & NW & $53^{\circ} 34^{\prime} 09.13905$ & $113^{\circ} 50^{\prime} 08.35688$ & - & - & 181 & 0.268 \\
\hline & $\mathrm{NE}$ & $53^{\circ} 34^{\prime} 09.19460$ & $113^{\circ} 50^{\prime} 07.28088$ & - & - & 180 & 0.264 \\
\hline & SE & $53^{\circ} 34^{\prime} 08.55968$ & $113^{\circ} 50^{\prime} 07.17711$ & - & - & 180 & 0.253 \\
\hline \multirow[t]{4}{*}{3} & SW & $53^{\circ} 33^{\prime} 48.46939$ & $113^{\circ} 50^{\prime} 06.61552$ & 312239.500 & 5938693.0 & 30 & 0.285 \\
\hline & NW & $53^{\circ} 33^{\prime} 49.23433$ & $113^{\circ} 50^{\prime} 06.67571$ & - & - & 80 & 0.487 \\
\hline & $\mathrm{NE}$ & $53^{\circ} 33^{\prime} 49.27831$ & $113^{\circ} 50^{\prime} 05.59935$ & - & - & 101 & 0.516 \\
\hline & SE & $53^{\circ} 33^{\prime} 48.59754$ & $113^{\circ} 50^{\prime} 05.55755$ & - & - & 151 & 0.328 \\
\hline \multirow[t]{4}{*}{4} & SW & $53^{\circ} 34^{\prime} 09.65077$ & $113^{\circ} 49^{\prime} 49.12233$ & 312587.250 & 5939334.5 & 107 & 0.268 \\
\hline & NW & $53^{\circ} 34^{\prime} 10.30560$ & $113^{\circ} 49^{\prime} 49.42554$ & - & - & 123 & 0.316 \\
\hline & $\mathrm{NE}$ & $53^{\circ} 34^{\prime} 10.43721$ & $113^{\circ} 49^{\prime} 48.30362$ & - & - & 131 & 0.282 \\
\hline & SE & $53^{\circ} 34^{\prime} 09.86316$ & $113^{\circ} 49^{\prime} 48.05714$ & - & - & 180 & 0.340 \\
\hline \multirow[t]{4}{*}{5} & SW & $53^{\circ} 33^{\prime} 55.12135$ & $113^{\circ} 49^{\prime} 33.22286$ & 312861.781 & 5938874.0 & 181 & 0.373 \\
\hline & NW & $53^{\circ} 33^{\prime} 55.72876$ & $113^{\circ} 49^{\prime} 33.37524$ & - & - & 183 & 0.287 \\
\hline & $\mathrm{NE}$ & $53^{\circ} 33^{\prime} 55.73599$ & $113^{\circ} 49^{\prime} 32.29199$ & - & - & 180 & 0.382 \\
\hline & SE & $53^{\circ} 33^{\prime} 55.17777$ & $113^{\circ} 49^{\prime} 32.20957$ & - & - & 57 & 0.230 \\
\hline \multirow[t]{4}{*}{6} & SW & $53^{\circ} 33^{\prime} 59.21169$ & $113^{\circ} 49^{\prime} 35.09838$ & 312832.313 & 5939001.5 & 183 & 0.264 \\
\hline & NW & $53^{\circ} 33^{\prime} 59.86100$ & $113^{\circ} 49^{\prime} 35.15226$ & - & - & 184 & 0.266 \\
\hline & $\mathrm{NE}$ & $53^{\circ} 33^{\prime} 59.88637$ & $113^{\circ} 49^{\prime} 34.03125$ & - & - & 143 & 0.299 \\
\hline & SE & $53^{\circ} 33^{\prime} 59.21711$ & $113^{\circ} 49^{\prime} 34.01951$ & - & - & 181 & 0.364 \\
\hline \multirow[t]{4}{*}{7} & SW & $53^{\circ} 34^{\prime} 03.16086$ & $113^{\circ} 49^{\prime} 32.53890$ & 312884.219 & 5939122.0 & 180 & 0.280 \\
\hline & NW & $53^{\circ} 34^{\prime} 03.78821$ & $113^{\circ} 49^{\prime} 32.71866$ & - & - & 180 & 0.328 \\
\hline & $\mathrm{NE}$ & $53^{\circ} 34^{\prime} 03.85251$ & $113^{\circ} 49^{\prime} 31.60285$ & - & - & 180 & 0.415 \\
\hline & SE & $53^{\circ} 34^{\prime} 03.24927$ & $113^{\circ} 49^{\prime} 31.38053$ & - & - & 98 & 0.348 \\
\hline \multirow[t]{4}{*}{8} & SW & $53^{\circ} 34^{\prime} 10.11794$ & $113^{\circ} 49^{\prime} 31.56646$ & 312910.656 & 5939336.0 & 209 & 0.291 \\
\hline & NW & $53^{\circ} 34^{\prime} 10.75148$ & $113^{\circ} 49^{\prime} 31.41186$ & - & - & 161 & 0.212 \\
\hline & $\mathrm{NE}$ & $53^{\circ} 34^{\prime} 10.65084$ & $113^{\circ} 49^{\prime} 30.36908$ & - & - & 165 & 0.320 \\
\hline & $\overline{S E}$ & $53^{\circ} 34^{\prime} 10.01816$ & $113^{\circ} 49^{\prime} 30.54914$ & - & - & 143 & 0.232 \\
\hline
\end{tabular}



Appendix 1. (Cont'd)

\begin{tabular}{|c|c|c|c|c|c|c|c|}
\hline $\begin{array}{l}\text { Detailed } \\
\text { plot\# }\end{array}$ & $\begin{array}{l}\text { Plot } \\
\text { Corner }\end{array}$ & Latitude & Longitude & Easting & Northing & $\begin{array}{l}\text { GPS points } \\
\text { collected }\end{array}$ & $\begin{array}{l}\text { Horizontal precision } \\
\text { differential } \\
\text { correction }(\mathrm{m})\end{array}$ \\
\hline \multirow[t]{4}{*}{9} & SW & $53^{\circ} 34^{\prime} 01.18929$ & $113^{\circ} 49^{\prime} 51.11260$ & 312540.250 & 5939074.5 & 1000 & 0.131 \\
\hline & NW & $53^{\circ} 34^{\prime} 01.84498$ & $113^{\circ} 49^{\prime} 51.11042$ & - & - & 1010 & 0.190 \\
\hline & $\mathrm{NE}$ & $53^{\circ} 34^{\prime} 01.82979$ & $113^{\circ} 49^{\prime} 50.01518$ & - & - & 1001 & 0.164 \\
\hline & $\overline{S E}$ & $53^{\circ} 34^{\prime} 01.17259$ & $113^{\circ} 49^{\prime} 50.02099$ & - & - & 1005 & 0.144 \\
\hline \multirow{4}{*}{10} & SW & $53^{\circ} 34^{\prime} 0813667$ & $13^{\circ} 00^{\prime} 4227611$ & 312711250 & 50302820 & 1200 & 0103 \\
\hline & NW & $53^{\circ} 34^{\prime} 08.76110$ & $113^{\circ} 49^{\prime} 42.43658$ & (1) & 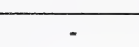 & 1227 & 0.120 \\
\hline & $\mathrm{NE}$ & $53^{\circ} 34^{\prime} 08.85962$ & $113^{\circ} 49^{\prime} 41.36795$ & - & - & 1201 & 0.123 \\
\hline & $\overline{S E}$ & $53^{\circ} 34^{\prime} 08.21920$ & $113^{\circ} 49^{\prime} 41.22667$ & - & - & 1200 & 0.122 \\
\hline \multirow[t]{4}{*}{11} & SW & $53^{\circ} 34^{\prime} 05.92946$ & $113^{\circ} 48^{\prime} 54.14698$ & 313595.719 & 5939179.0 & 1200 & 0.134 \\
\hline & NW & $53^{\circ} 34^{\prime} 06.58275$ & $113^{\circ} 48^{\prime} 54.12196$ & - & - & 1200 & 0.095 \\
\hline & $\overline{N E}$ & $53^{\circ} 34^{\prime} 06.56470$ & $113^{\circ} 48^{\prime} 53.04538$ & - & - & 1226 & 0.109 \\
\hline & $S E$ & $53^{\circ} 34^{\prime} 05.91824$ & $113^{\circ} 48^{\prime} 53.06697$ & - & - & 1200 & 0.114 \\
\hline \multirow[t]{4}{*}{12} & SW & $53^{\circ} 34^{\prime} 08.63048$ & $113^{\circ} 49^{\prime} 08.30753$ & 313337.344 & 5939272.5 & 1621 & 0.114 \\
\hline & NW & $53^{\circ} 34^{\prime} 09.25243$ & $113^{\circ} 49^{\prime} 08.48749$ & - & - & 908 & 0.115 \\
\hline & $\mathrm{NE}$ & $53^{\circ} 34^{\prime} 09.39395$ & $113^{\circ} 49^{\prime} 07.43955$ & - & - & 1155 & 0.140 \\
\hline & SE & $53^{\circ} 34^{\prime} 08.75321$ & $113^{\circ} 49^{\prime} 07.22356$ & - & - & 339 & 0.258 \\
\hline \multirow[t]{4}{*}{13} & SW & $53^{\circ} 33^{\prime} 41.04597$ & $113^{\circ} 48^{\prime} 37.64951$ & 313865.688 & 5938397.5 & 881 & 0.137 \\
\hline & NW & $53^{\circ} 33^{\prime} 41.66357$ & $113^{\circ} 48^{\prime} 37.48387$ & - & - & 627 & 0.300 \\
\hline & $\mathrm{NE}$ & $53^{\circ} 33^{\prime} 41.60516$ & $113^{\circ} 48^{\prime} 36.41210$ & - & - & 552 & 0.199 \\
\hline & SE & $53^{\circ} 33^{\prime} 41.00250$ & $113^{\circ} 48^{\prime} 36.54995$ & - & - & 494 & 0.109 \\
\hline 14 & centre & $53^{\circ} 33^{\prime} 50.74949$ & $113^{\circ} 48^{\prime} 38.20806$ & 313865.688 & 5938697.5 & 1300 & 0.115 \\
\hline \multirow[t]{4}{*}{15} & SW & $53^{\circ} 33^{\prime} 55.30835$ & $113^{\circ} 48^{\prime} 36.65012$ & 313902.969 & 5938837.5 & 1200 & 0.169 \\
\hline & $\overline{N W}$ & $53^{\circ} 33^{\prime} 55.90359$ & $113^{\circ} 48^{\prime} 36.73142$ & - & - & 1765 & 0.120 \\
\hline & $\mathrm{NE}$ & $53^{\circ} 33^{\prime} 55.98198$ & $113^{\circ} 48^{\prime} 35.67792$ & - & - & 1197 & 0.132 \\
\hline & $\overline{S E}$ & $53^{\circ} 33^{\prime} 55.35461$ & $113^{\circ} 48^{\prime} 35.59198$ & - & - & 906 & 0.173 \\
\hline \multirow{4}{*}{16} & SW & $53^{\circ} 33^{\prime} 5487350$ & $11^{\circ} 48^{\prime} 3234858$ & 313982094 & $5938823=$ & 608 & 0018 \\
\hline & NW & $53^{\circ} 33^{\prime} 5560196$ & $113^{\circ} 48^{\prime} 3237951$ & 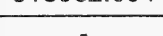 & (1) & 601 & 0182 \\
\hline & $\mathrm{NE}$ & $53^{0} 33^{\prime} 5559505$ & $113^{\circ} 48^{\prime} 3133403$ & $-\theta^{-1}$ & $-\theta_{0}$ & $\frac{505}{50}$ & 0171 \\
\hline & SE & $53^{\circ} 33^{\prime} 54.98934$ & $113^{\circ} 48^{\prime} 31.27864$ & - & - & 81 & 0.213 \\
\hline \multirow[t]{4}{*}{17} & SW & $53^{\circ} 33^{\prime} 55.69812$ & $113^{\circ} 49^{\prime} 03.54245$ & 313409.469 & 5938870.0 & 553 & 0.219 \\
\hline & NW & $53^{\circ} 33^{\prime} 56.41476$ & $113^{\circ} 49^{\prime} 03.75723$ & - & - & 660 & 0.197 \\
\hline & $\mathrm{NE}$ & $53^{\circ} 33^{\prime} 56.51637$ & $113^{\circ} 49^{\prime} 02.69394$ & - & - & 308 & 0.341 \\
\hline & SE & $53^{\circ} 33^{\prime} 55.90280$ & $113^{\circ} 49^{\prime} 02.46085$ & - & - & 750 & 0.195 \\
\hline
\end{tabular}



Appendix 1. (Cont'd)

\begin{tabular}{|c|c|c|c|c|c|c|c|}
\hline $\begin{array}{c}\text { Detailed } \\
\text { plot\# }\end{array}$ & $\begin{array}{l}\text { Plot } \\
\text { Corner }\end{array}$ & Latitude & Longitude & Easting & Northing & $\begin{array}{l}\text { GPS points } \\
\text { collected }\end{array}$ & $\begin{array}{l}\text { Horizontal precision } \\
\text { differential } \\
\text { correction }(\mathrm{m})\end{array}$ \\
\hline \multirow[t]{4}{*}{18} & SW & $53^{\circ} 34^{\prime} 02.22217$ & $113^{\circ} 49^{\prime} 08.51287$ & 313325.688 & 5939074.5 & 900 & 0.257 \\
\hline & NW & $53^{\circ} 34^{\prime} 02.85396$ & $113^{\circ} 49^{\prime} 08.55727$ & - & - & 511 & 0.187 \\
\hline & NE & $53^{\circ} 34^{\prime} 02.88212$ & $113^{\circ} 49^{\prime} 07.47769$ & - & - & 1480 & 0.134 \\
\hline & SE & $53^{\circ} 34^{\prime} 02.20462$ & $113^{\circ} 49^{\prime} 07.49285$ & - & - & 1202 & 0.164 \\
\hline
\end{tabular}





\section{APPENDIX 2}

Color Photographs of

Representative Features 



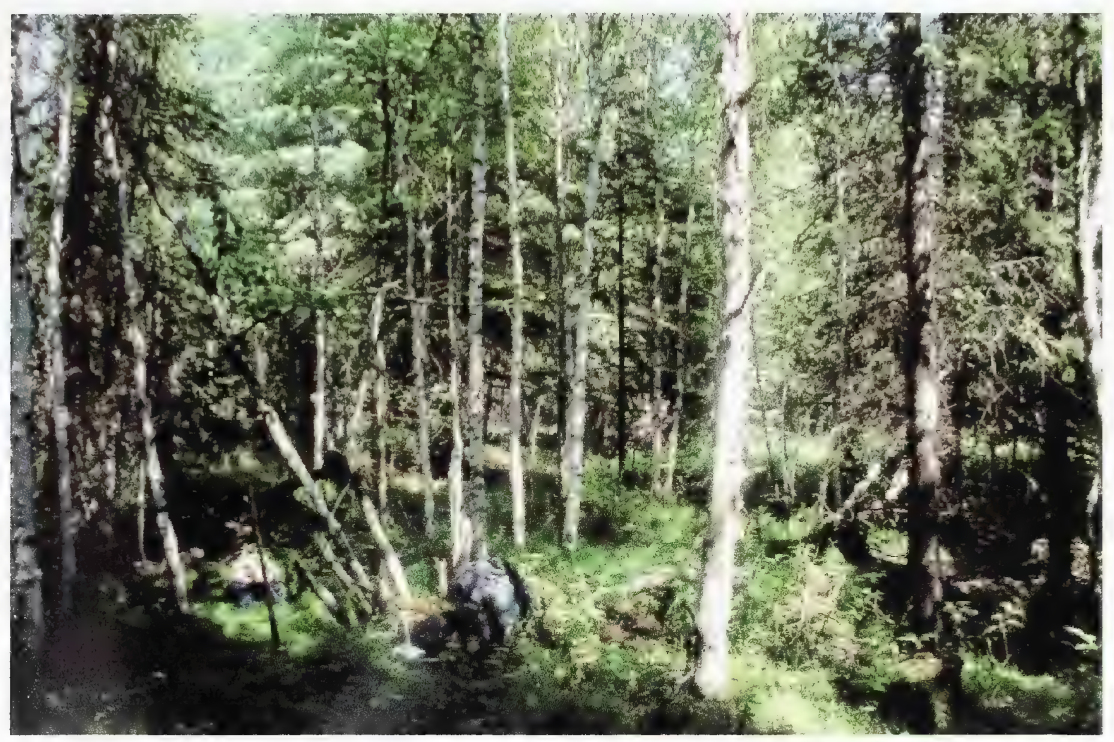

Plate 1: Alaska birch-balsam poplar/dewberry/sedge community subtype (BP1) occurring on Orthic Gleysols, carbonated Terric Humisols and carbonated Terric Mesisols. This photo was taken in the vicinity of detailed plot \#62.

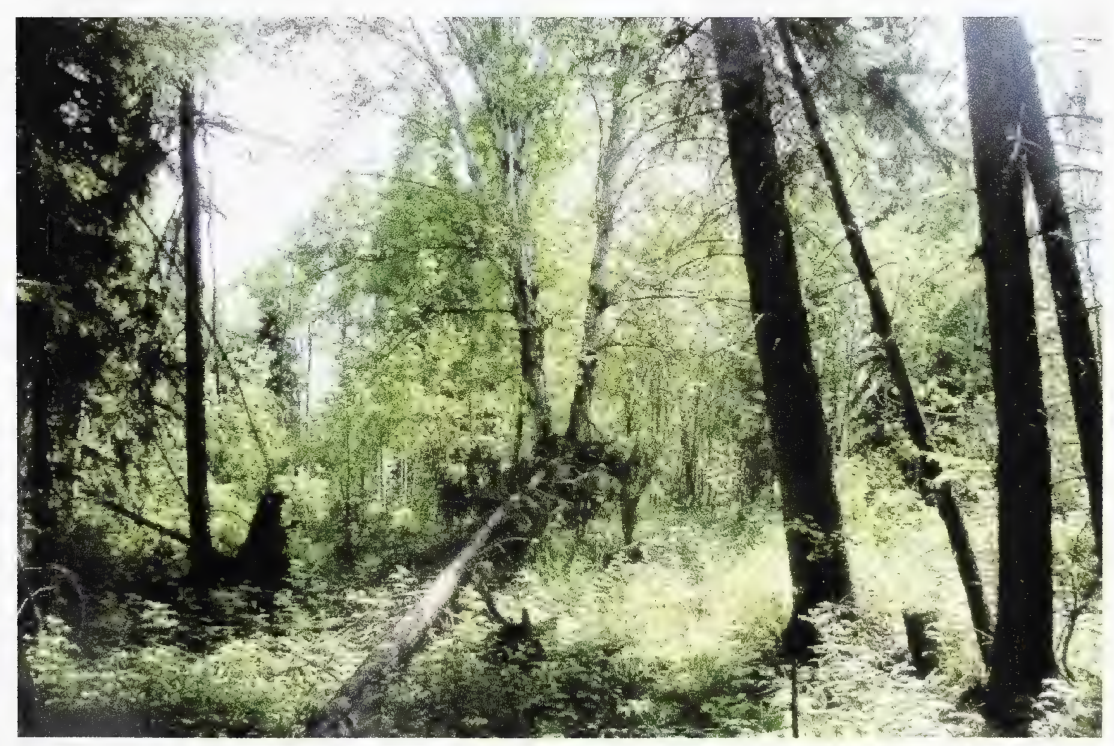

Plate 2: Alaska birch-balsam poplar /bunchberry community subtype (BP2) occupying carbonated Rego Gleysols. This community subtype has a more open tree canopy and older, taller trees compared to BP1 community subtype. This photo was taken at reconnaissance plot \#67. 



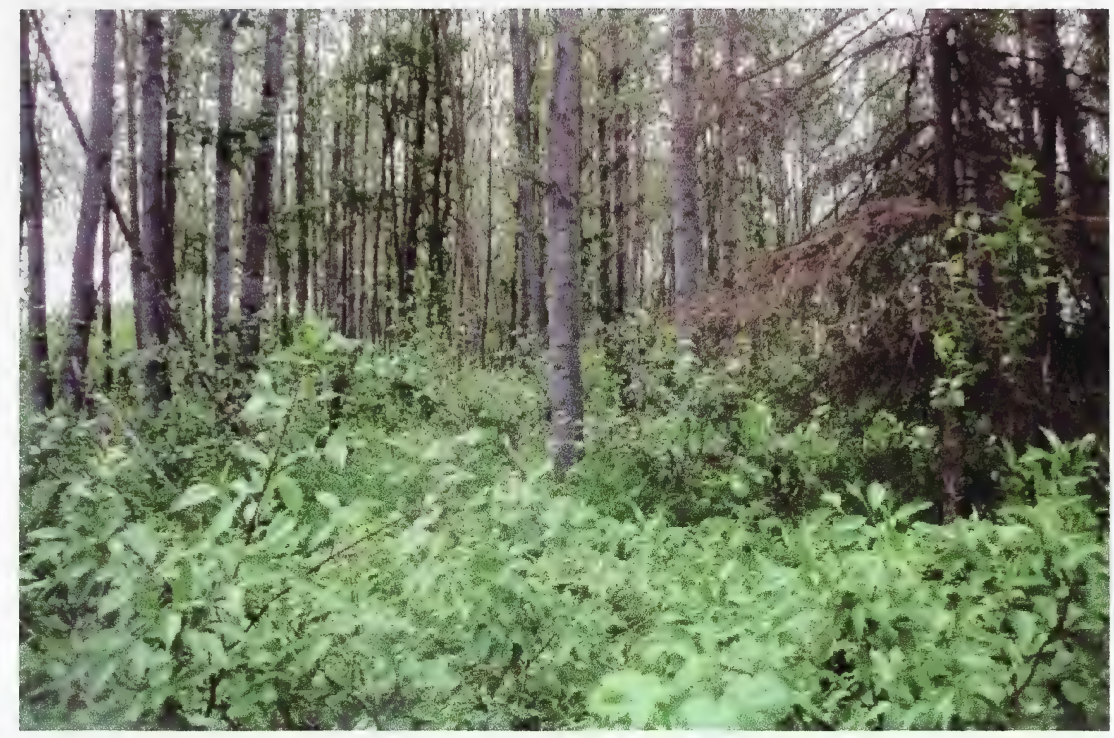

Plate 3: Balsam poplar-aspen/dogwood community subtype (PA4) occurring on carbonated Terric Mesisols, carbonated Terric Mesic Humisols and Typic Mesisols. This photo was taken north of reconnaissance plot \#51.

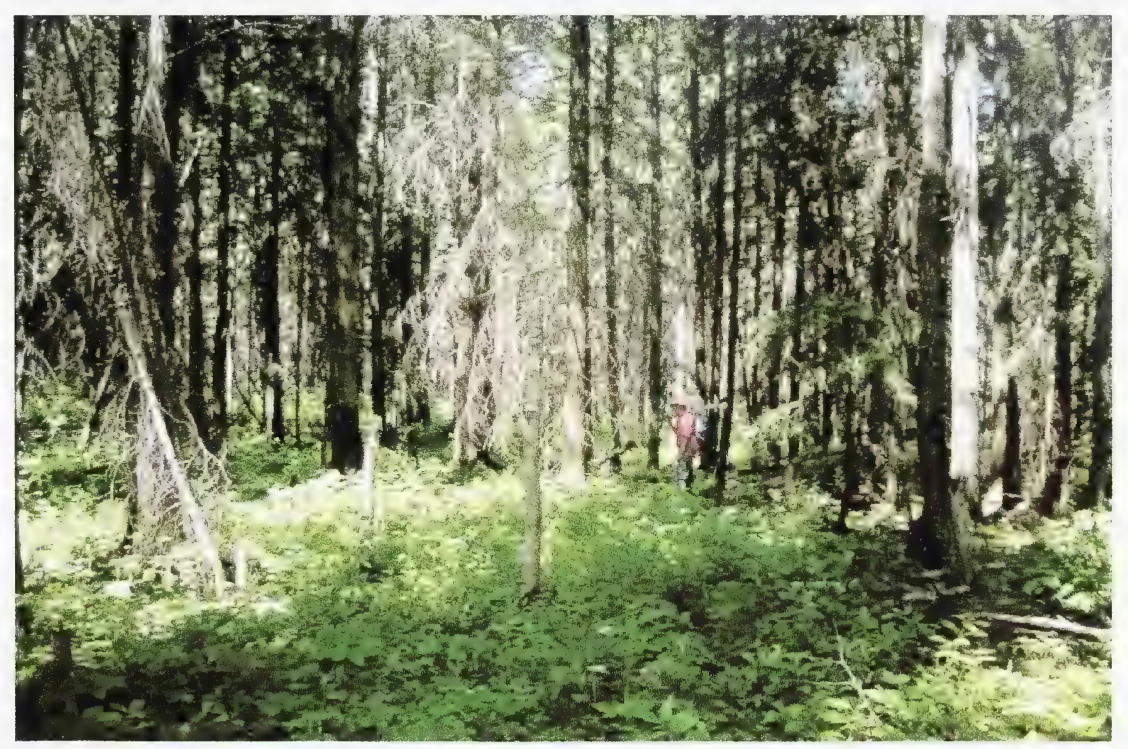

Plate 4: White spruce-balsam poplar/dewberry community subtype (SP1) occupying Orthic Gleysols, carbonated Terric Humisols, and carbonated Terric Mesisols. This photo was taken at reconnaissance plot \#81. 



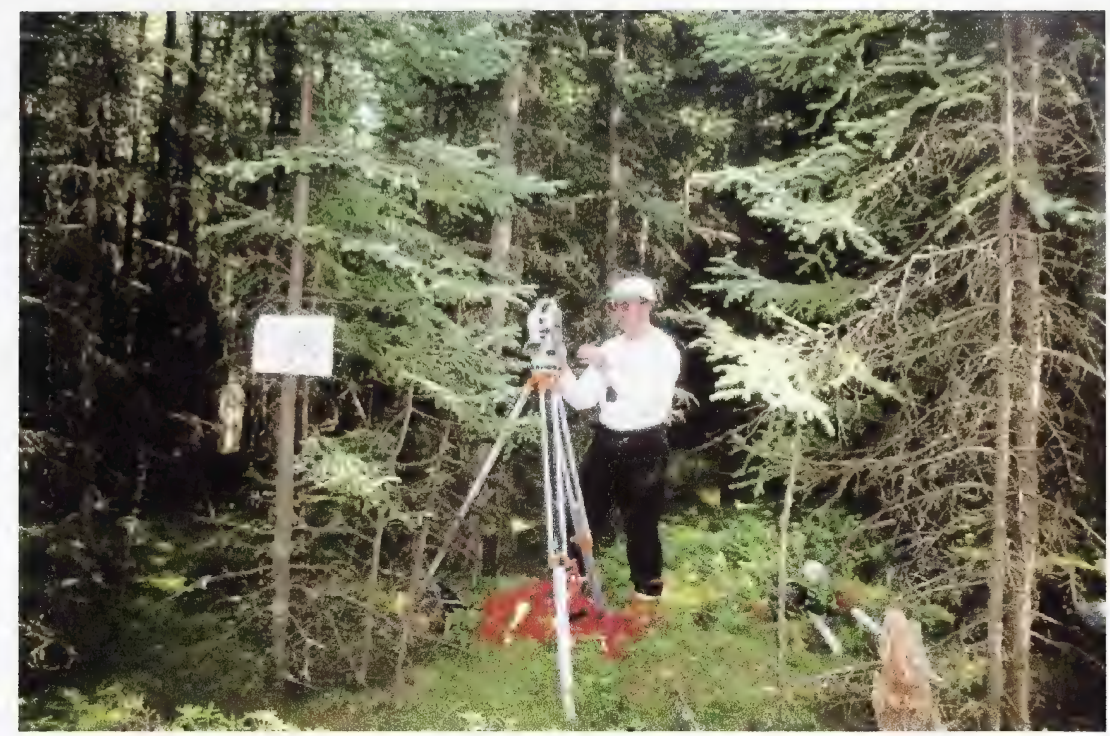

Plate 5: Black spruce-tamarack/Labrador tea/feather moss community subtype (SL1) occurring on various organic soils. The establishment of the plot area using a theodolite is also shown. This photo was taken at detailed plot \#8.

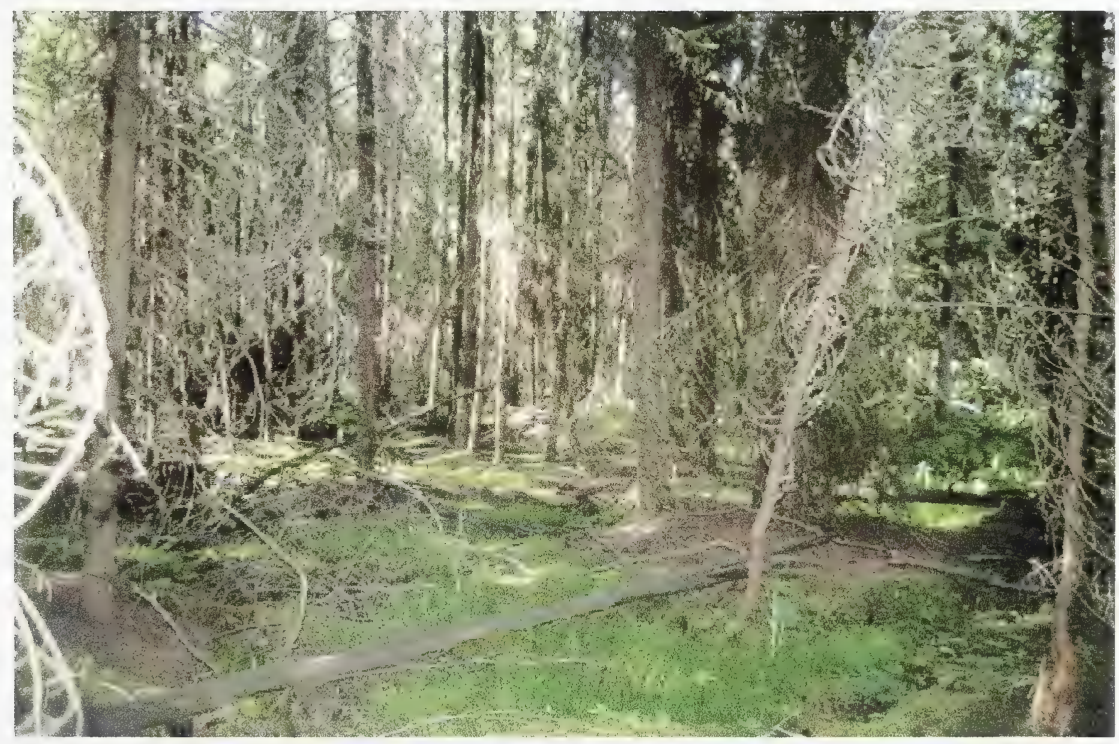

Plate 6: White spruce-black spruce/dewberry/sedge/feather moss community subtype (SS1) mainly occurring on carbonated Terric Mesisols, carbonated Terric Humisols, carbonated Terric Mesic Humisols, and carbonated Rego Gleysols. This photo was taken at reconnaissance plot $\# 72$. 



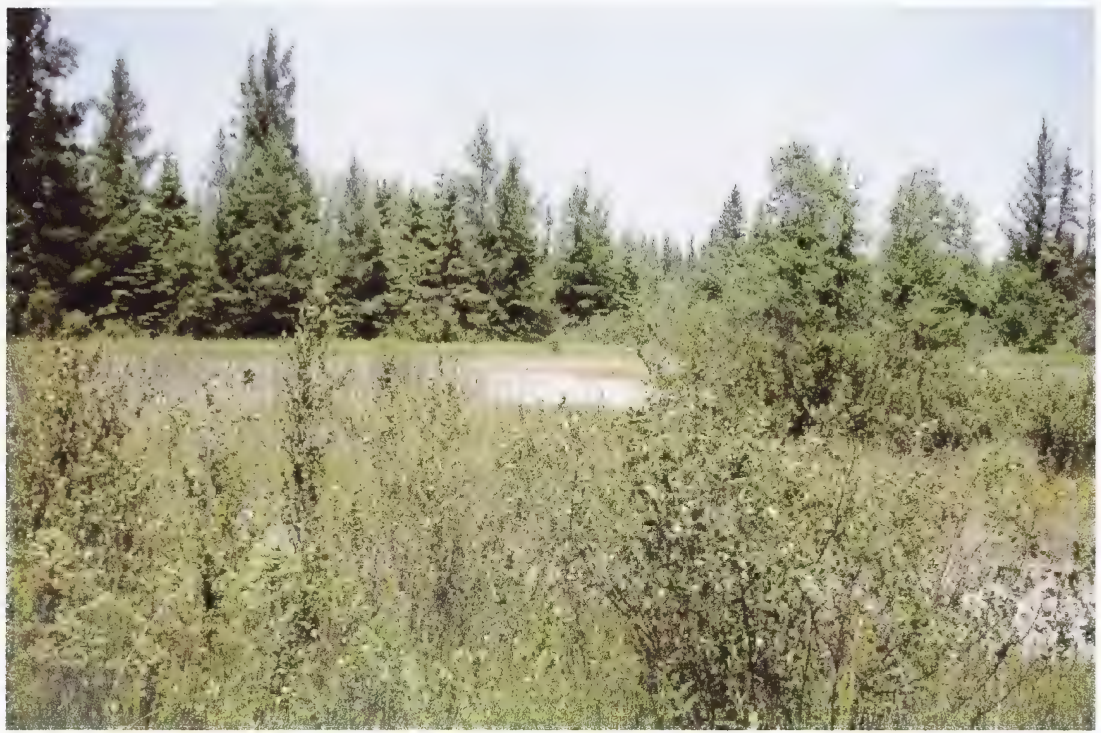

Plate 7: Dwarf birch/sedge/moss fen community subtype (FE2) occurring on carbonated Rego Gleysols. This fen community subtype is a mosaic of shallow water areas (marl ponds), slightly raised areas mainly supporting moss and herb species, and the higher areas inhabited by shrub and stunted tree species with associated moss and forb vegetation. This photo was taken at reconnaissance plot \#27.

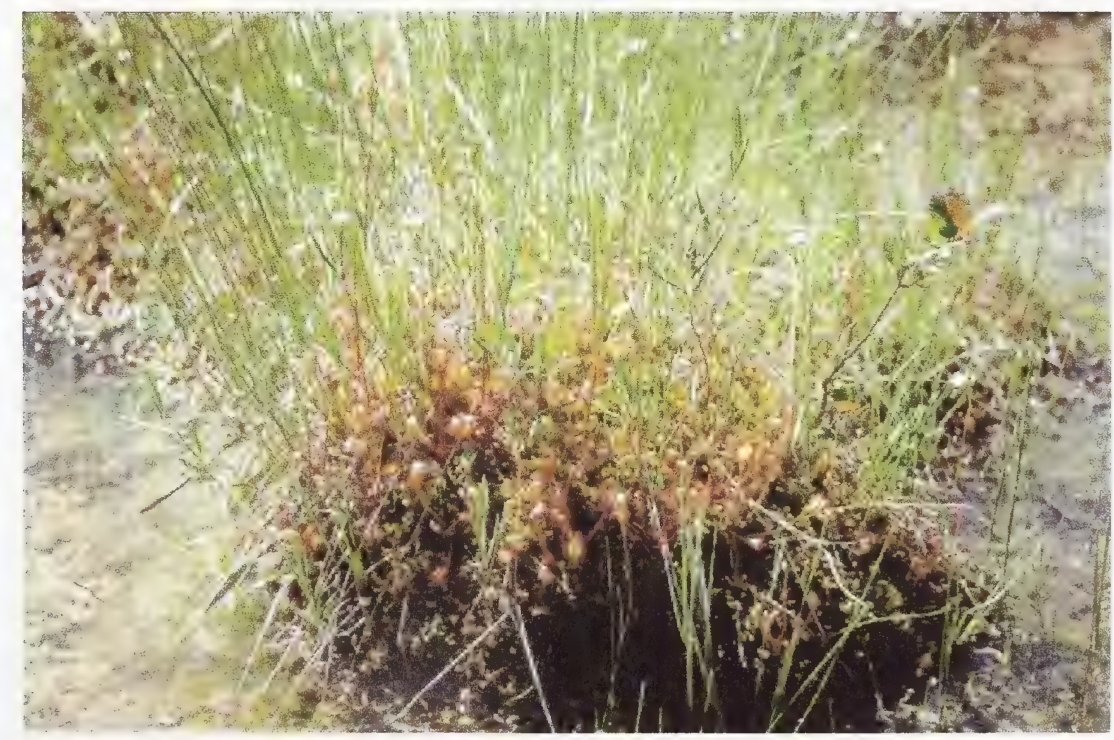

Plate 8: Oblong-leaved sundew (Drosera anglica) in bloom. It occupies fen areas within the project area. This photo was taken at reconnaissance plot \#86. 



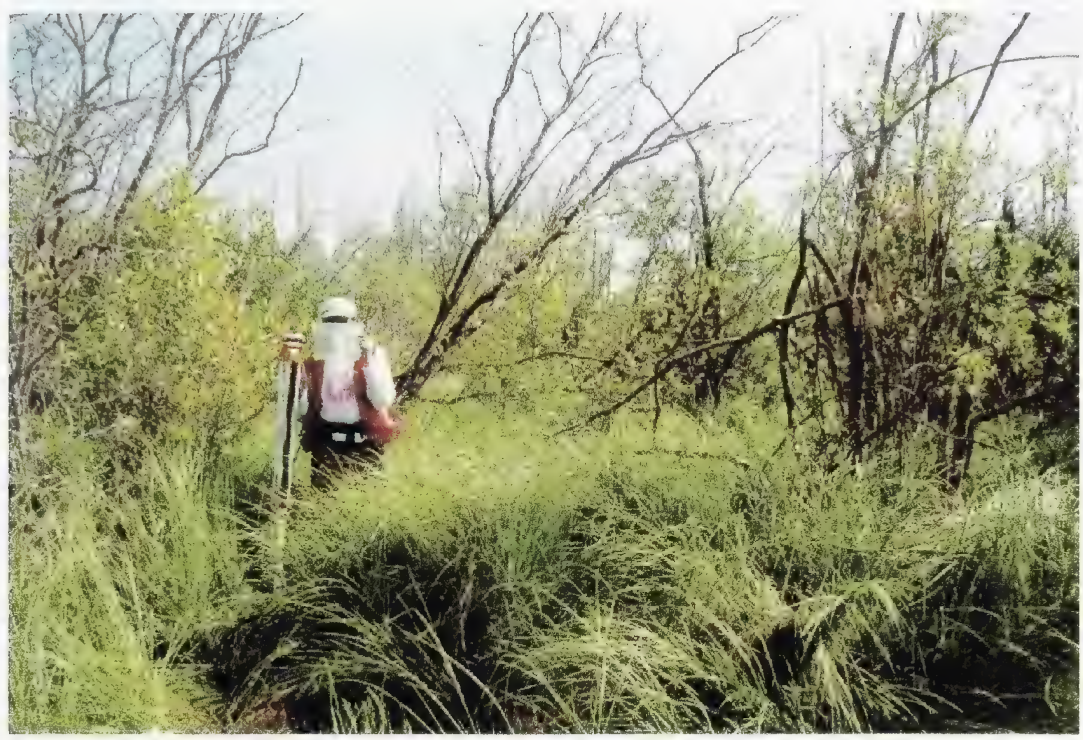

Plate 9: Willow/sedge-bluejoint community type (WS) occurring on carbonated Typic Mesisols. This photo was taken at detailed plot \#1.

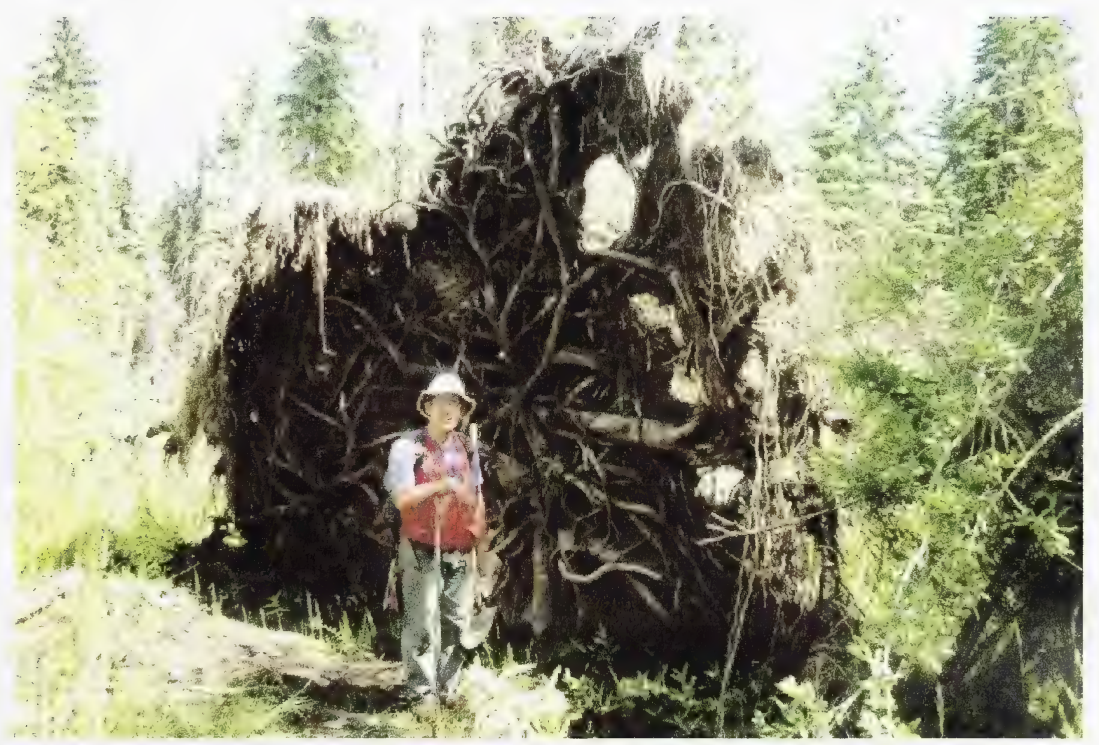

Plate 10: Wind-throw is one of the disturbance types influencing the dynamics of vegetation communities within Wagner Natural Area. This photo was taken near reconnaissance plot \#31, within the white spruce-black spruce/dewberry/sedge/feather moss community subtype (SS1). 



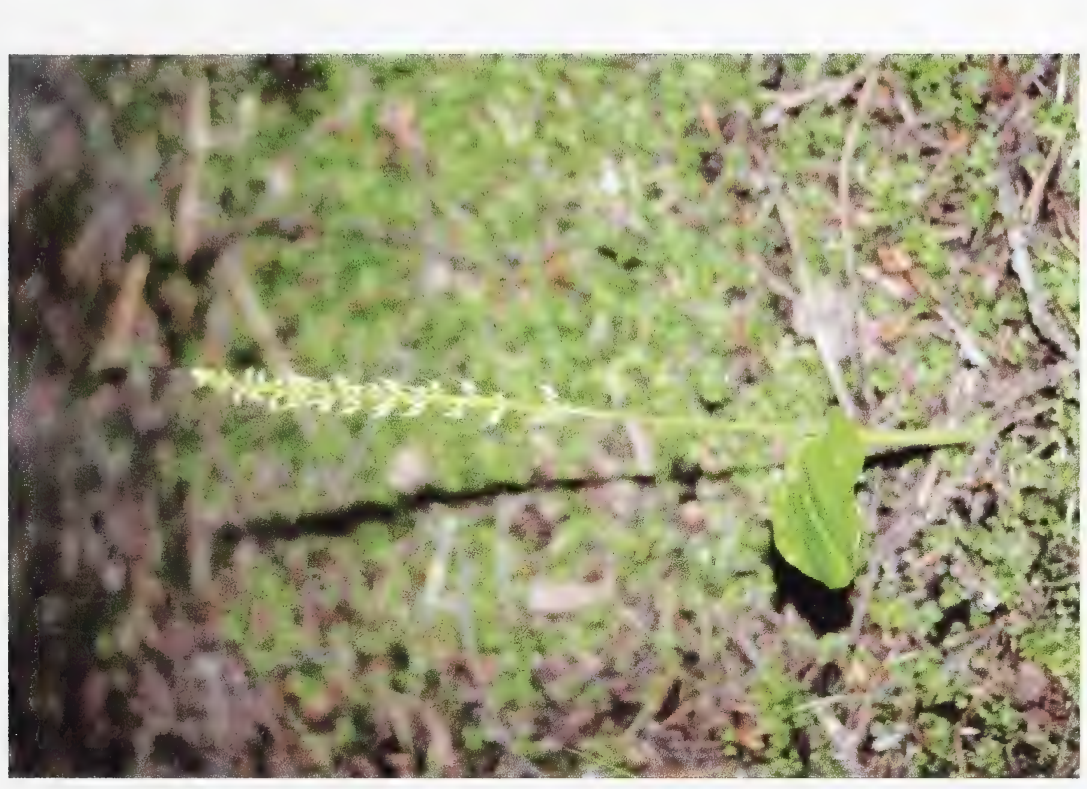

䒠总宗

手

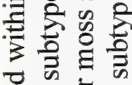

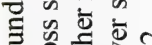

을 해을

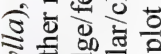

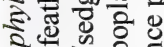

ङ

는

क 형

ते क्ष

s.

च क्ष के क्ष

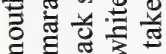

제 궁

क ว่

을

등 흥 흥

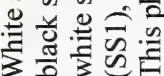

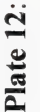
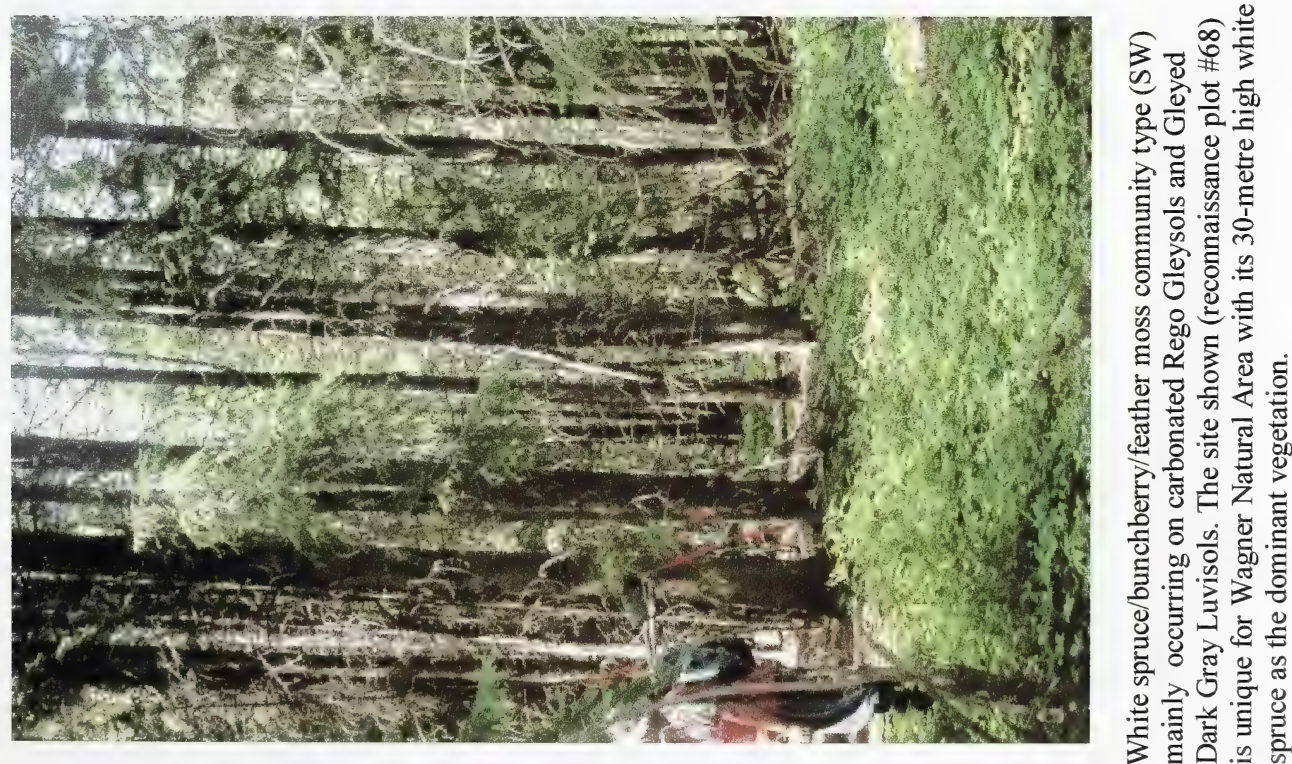

$\frac{}{2}$ 



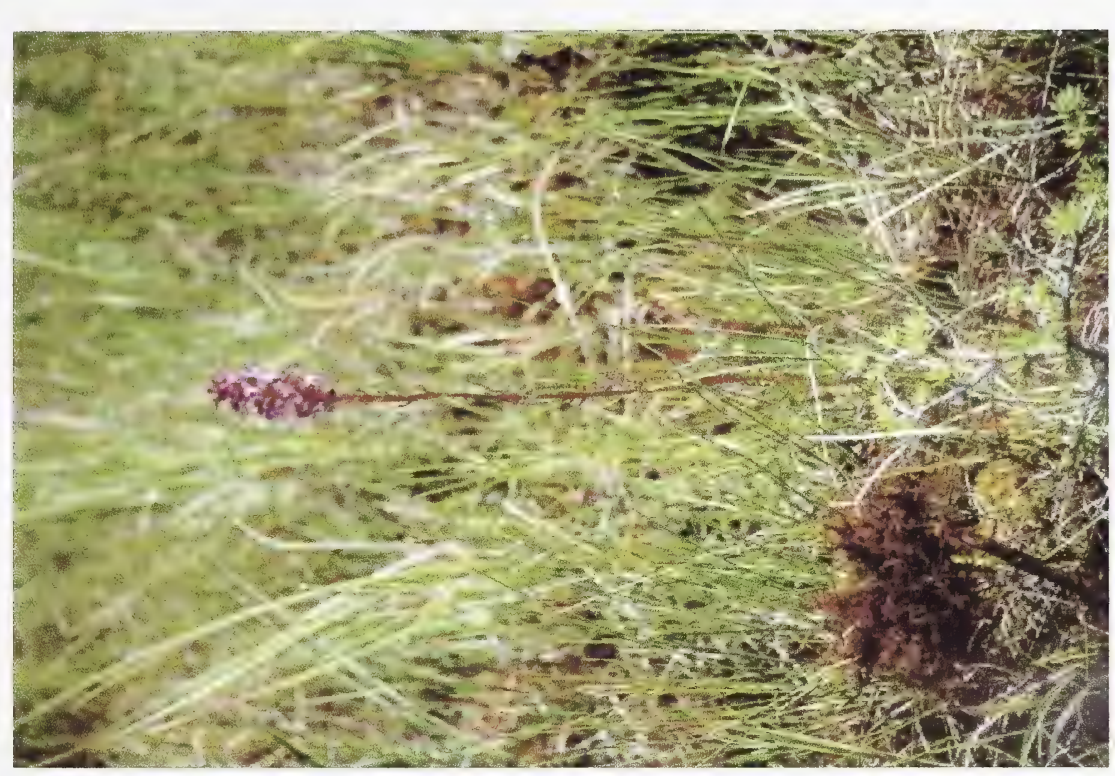

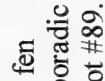

옹 क을

पू :

.

चु

क्ष

के.

:

ริ

ङ

ซ ส

कo

a.

혼

: 옹

$8 . \exists$

$\checkmark$ 을

곡

ஸे.

들

융 ह 릉

巧 $0 . \Xi$

$\frac{\dot{ \pm}}{\frac{\mathrm{g}}{\mathrm{E}}}$

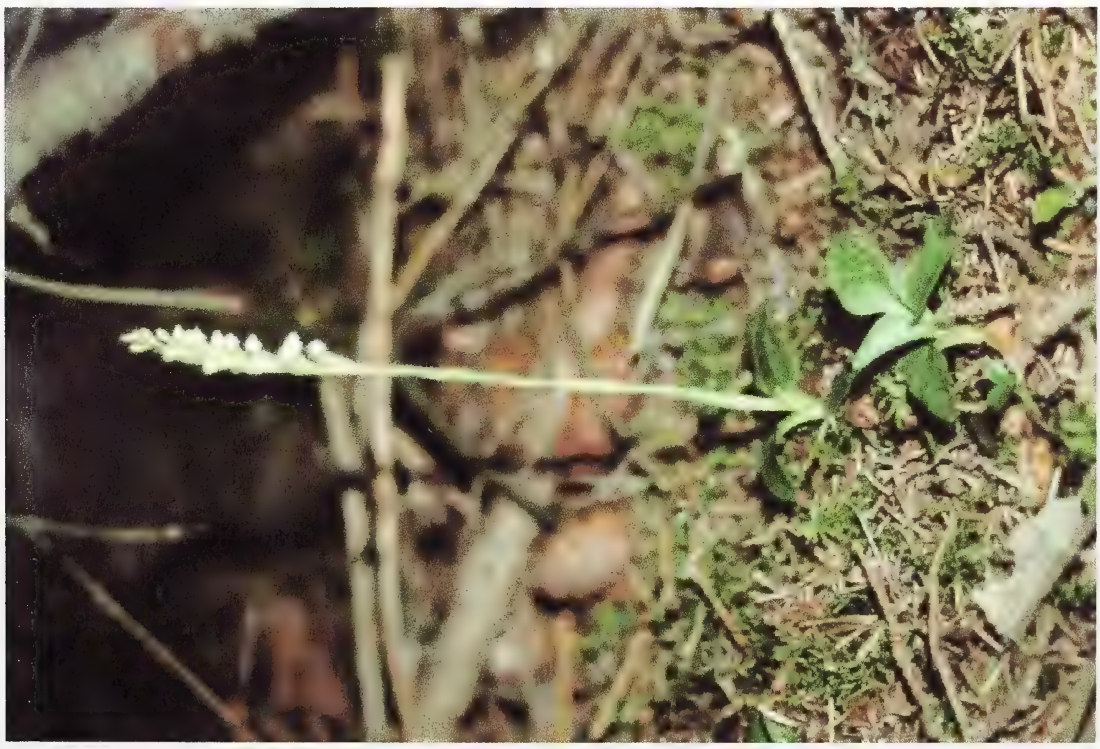

$\stackrel{Ð}{ \pm}$

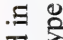

.

은

(ิ)

है ह

कू

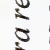

힐

క్

ऽั

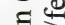

들

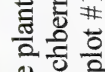

党 手

जิ

릴

흔

密站交

ले

$\frac{\pi}{\frac{\pi}{a}}$ 

APPENDIX 3

Soil Sample List 

Appendix 3. Soil Sample List

\begin{tabular}{|c|c|c|}
\hline Sample Number & Horizon & Type of Sample \\
\hline WP2 & Apk & Grab \\
\hline IVP2 & Apk & Composite \\
\hline WP2 & Apk & Bulk Density \\
\hline WP2 & Btk & Grab \\
\hline WP2 & Btk & Composite \\
\hline WP2 & Btk & Bulk Density \\
\hline WP2 & $\mathrm{Ck}$ & Grab \\
\hline W9 & $\mathrm{Ap}$ & Grab \\
\hline W9 & $\mathrm{Ap}$ & Composite \\
\hline W9 & Ap & Bulk Density \\
\hline W9 & Ahe & Grab \\
\hline W9 & $\mathrm{Ae}$ & Grab \\
\hline W9 & $\mathrm{Bt}$ & Grab \\
\hline W9 & $\mathrm{Bt}$ & Composite \\
\hline W9 & $\mathrm{Bt}$ & Bulk Density \\
\hline W9 & $\mathrm{BC} 1$ & Grab \\
\hline W9 & $\mathrm{BC} 2$ & Grab \\
\hline W10 & Ap & Grab \\
\hline $\mathrm{W} 10$ & $\mathrm{Ap}$ & Composite \\
\hline W10 & Ap & Bulk Density \\
\hline W10 & $\mathrm{Bt}$ & Grab \\
\hline $\mathrm{W} 10$ & $\mathrm{Bt}$ & Composite \\
\hline W10 & $\mathrm{Bt}$ & Bulk Density \\
\hline W10 & $\mathrm{Ck}$ & Grab \\
\hline W11 & Apk & Grab \\
\hline W11 & Apk & Composite \\
\hline W11 & Apk & Bulk Density \\
\hline W11 & Aek & Grab \\
\hline W11 & Aek & Composite \\
\hline W11 & Aek & Bulk Density \\
\hline W11 & $\mathrm{Btk}$ & Grab \\
\hline W11 & Btk & Composite \\
\hline W11 & $\mathrm{Ck}$ & Grab \\
\hline W12 & Ahk & Grab \\
\hline W12 & Ahk & Composite \\
\hline W12 & Ahk & Bulk Density \\
\hline W12 & $\mathrm{Ae}$ & Grab \\
\hline W12 & $\mathrm{Ae}$ & Bulk Density \\
\hline W12 & Btkgj & Grab \\
\hline W12 & Btkgj & Composite \\
\hline W12 & Ckg & Grab \\
\hline W16 & Ckg (Oco) & Grab \\
\hline W16 & Ckg (Oco) & Bulk Density \\
\hline
\end{tabular}





\section{APPENDIX 4 \\ Soil Polygon Attribute Data}





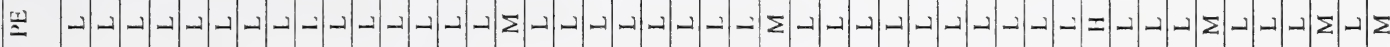

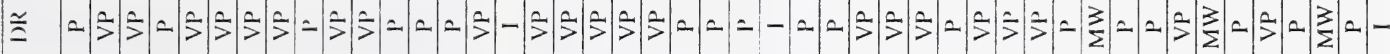

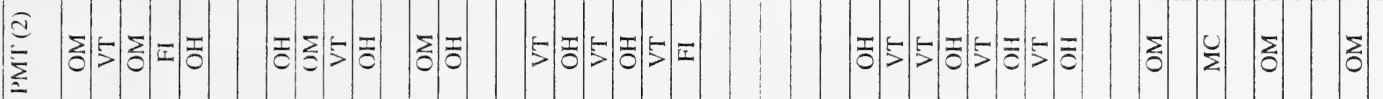

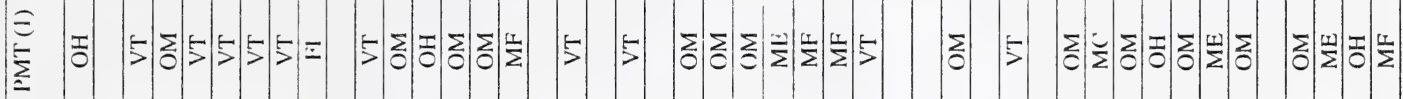

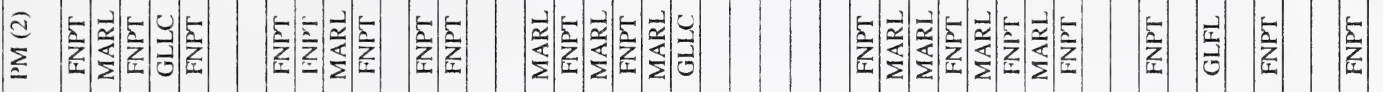

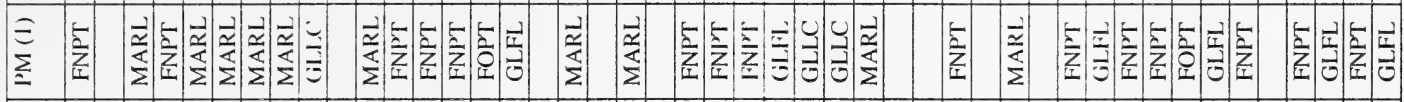

爱

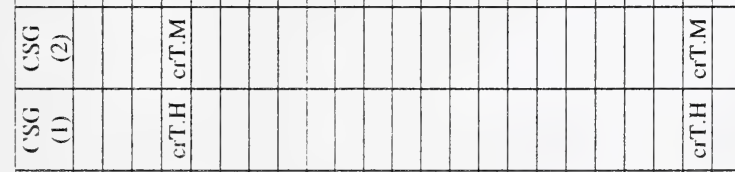

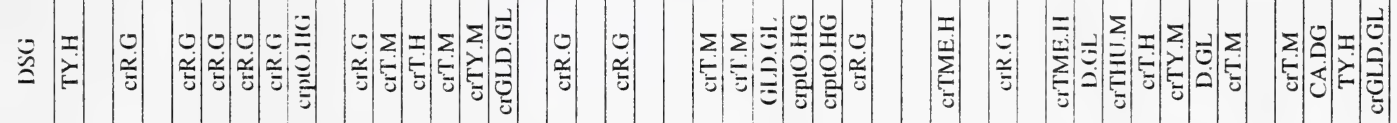

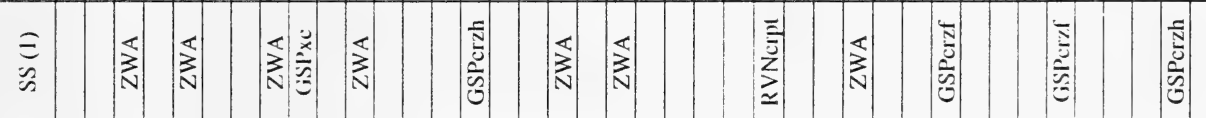

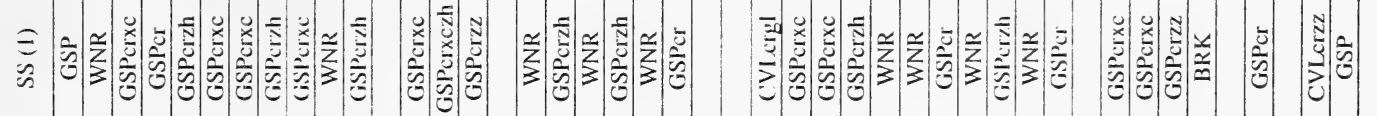

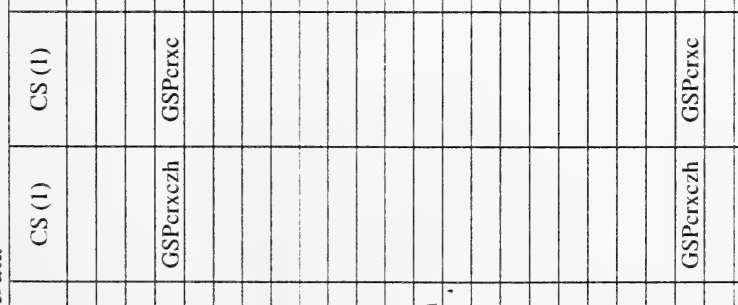

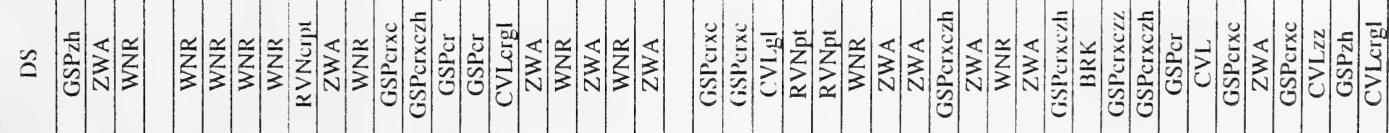

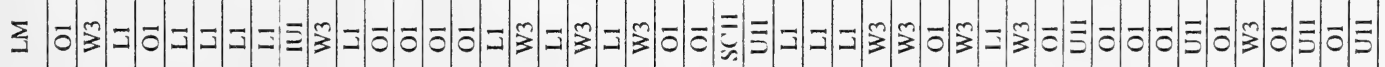

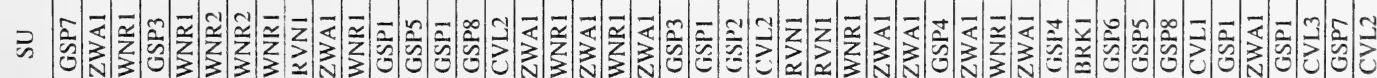
ड̃

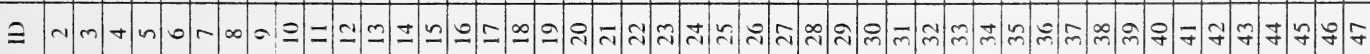





\section{Soil Polygon Attribute Legend}

Title

\section{GP \\ $\mathrm{SU}$ \\ LM \\ DS \\ CS \\ SS \\ DSG \\ CSG \\ SSG \\ PM \\ PMT \\ DR \\ PE}

\section{Series}

BRK

CVLcrgl

CVL

CVLzz

GSPcr

GSPcrxc

GSPcrxczh

GSPcrxczz

GSPcrzf

GSPcrzh

GSPcrzz

GSPzh

RVNcrpt

WNR

ZWA

\section{Subgroup}

\section{CA.DG}

crGLD.GL

crME.H

crptO.HG

crR.G

crTHU.M

crT.H

crT.M

crTME.H

crTY.H

crTY.M

D.GL

LM.M

TY.H

TY.M
Graphical Polygon

Soil Unit

Landscape Model

Dominant Series

Co-dominant Series

Significant Series

Dominant Subgroup

Co-dominant Subgroup

Significant Subgroup

Parent Material

Parent Material Texture

Drainage

Perviousness

\section{Brightbank}

carbonated, gleyed Carvel

Carvel

atypical Carvel

carbonated Goldenspike

carbonated, terric Goldenspike

carbonated, terric, humic

Goldenspike

carbonated, terric, atypical,

Goldenspike

carbonated, fibric Goldenspike

carbonated, humic Goldenspike

carbonated, atypical Goldenspike

humic Goldenspike

carbonated, peaty Raven

Wagner

Water

\section{Calcareous Dark Gray}

Chernozem

carbonated Gleyed Dark Gray

Luvisol

carbonated Mesic Humisol

carbonated peaty Orthic Humic

Gleysol

carbonated Rego Gleysol

carbonated Terric Humic Mesisol

carbonated Terric Humisol

carbonated Terric Mesisol

carbonated Terric Mesic Humisol

carbonated Typic Humisol

carbonated Typic Mesisol

Dark Gray Luvisol

Limnic Mesisol

Typic Humisol

Typic Mesisol

\section{Parent Material}

$\begin{array}{ll}\text { FNPT } & \text { Fen peat } \\ \text { FOPT } & \text { Forest peat } \\ \text { GLLC } & \text { Glaciolacustrine } \\ \text { GLFL } & \text { Glaciofluvial } \\ \text { MARL } & \text { Marl }\end{array}$

\section{Parent Material Texture}

FI

$\mathrm{MC}$

ME

MF

$\mathrm{OH}$

$\mathrm{OM}$

VT

fine (clay, silty clay)

moderately coarse (sandy loam)

medium (loam, silt loam)

moderately fine (sandy clay loam, clay

loam and silty clay loam)

organic, humic

organic, mesic

variable texture

\section{Drainage}

I

MW

$\mathrm{P}$

VP

imperfect

moderately well

poor

very poorly

\section{Perviousness}

$\begin{array}{ll}\text { L } & \text { Low } \\ \text { M } & \text { Medium } \\ \text { H } & \text { High }\end{array}$





\section{APPENDIX 5 \\ Vegetation Attribute Polygon Data}





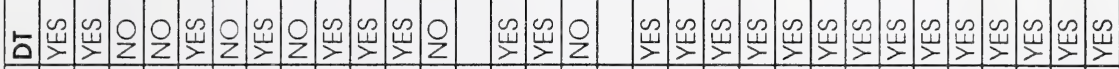

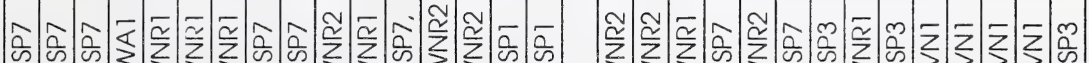

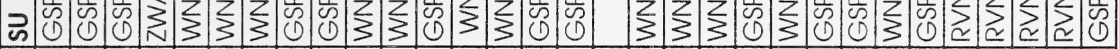

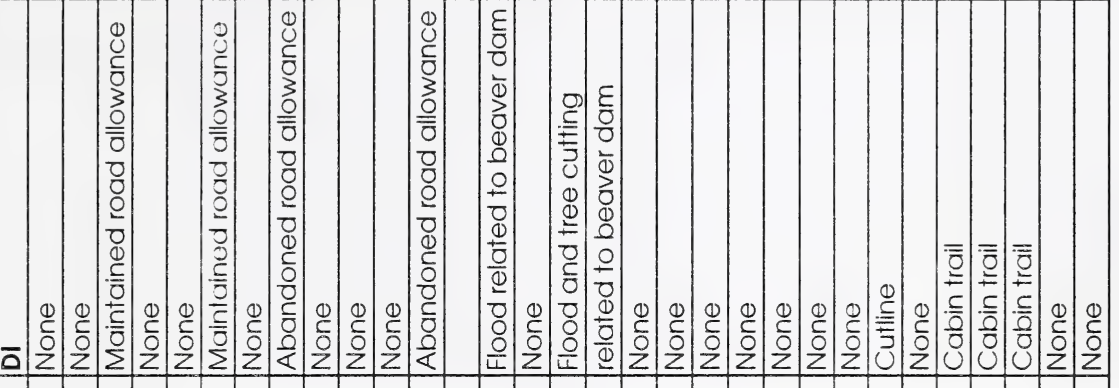

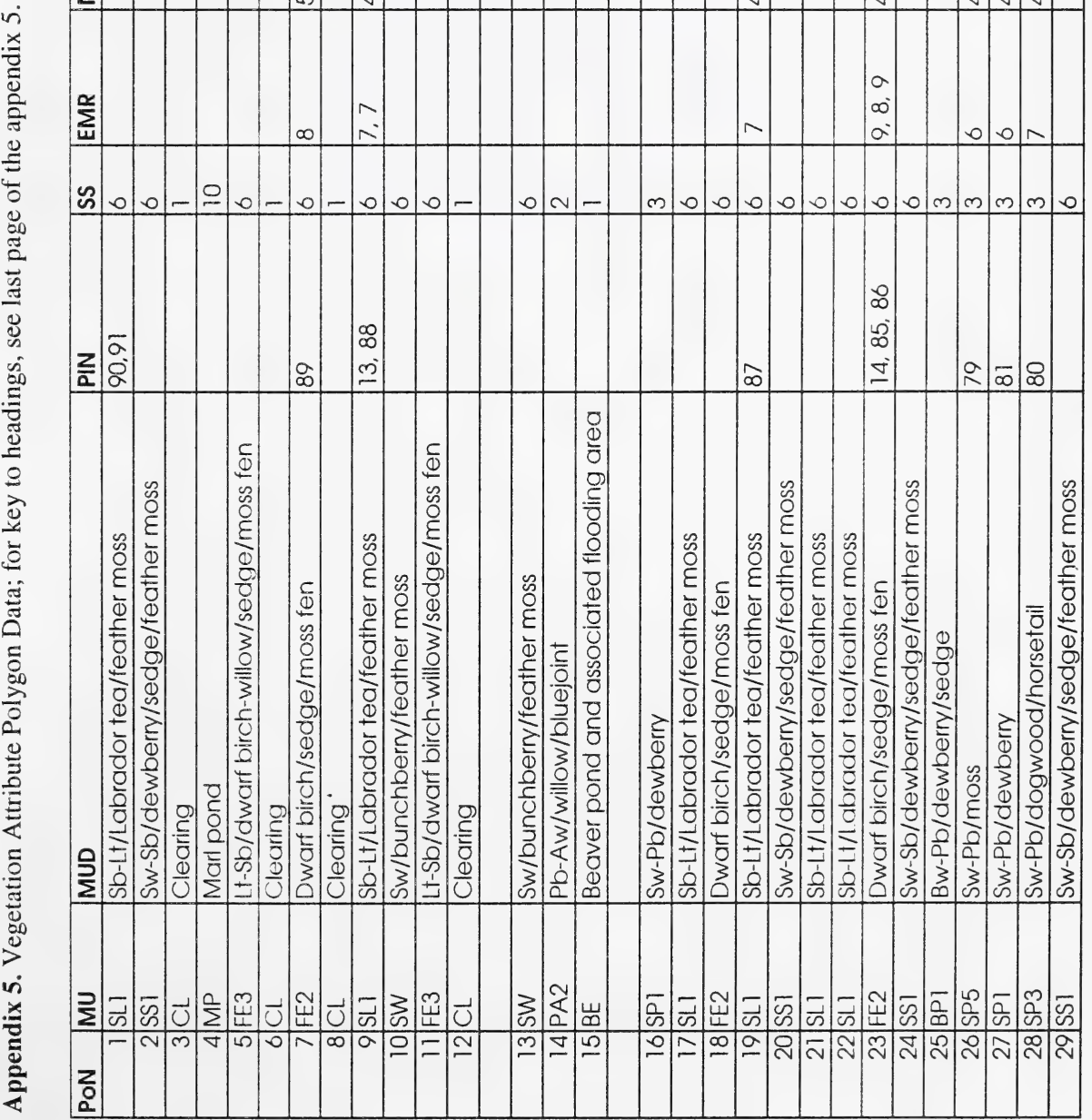





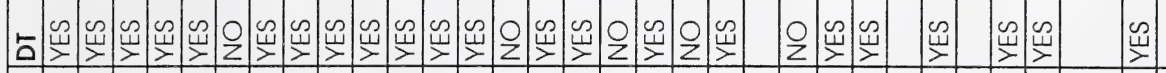

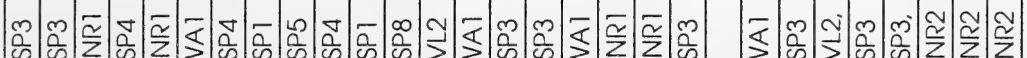

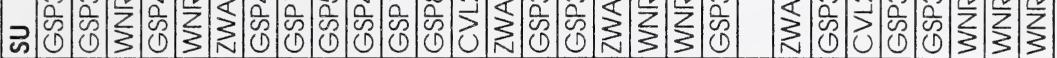

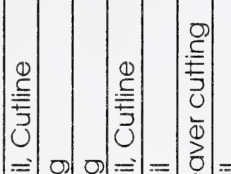

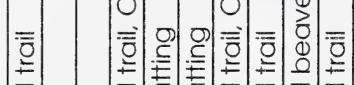

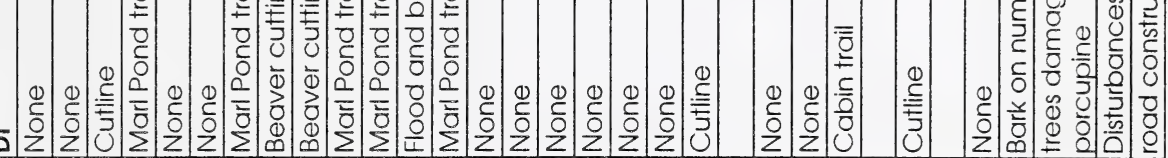

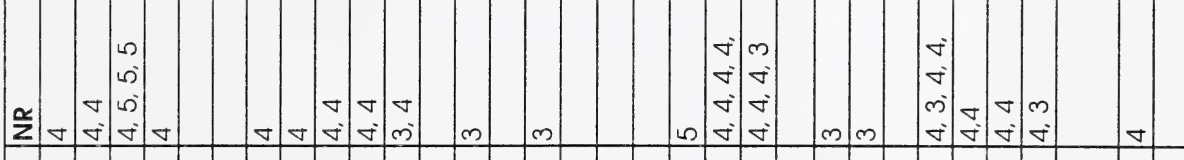

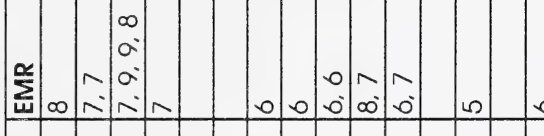

\begin{tabular}{l|l}
0 & 0 \\
$\infty$ & $\infty$ \\
$\infty$ & $\infty$
\end{tabular}

ris

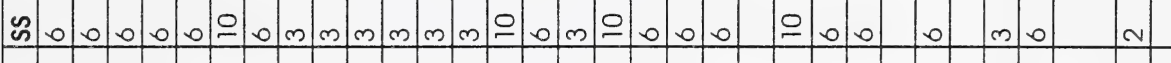
$\sqrt{2}$

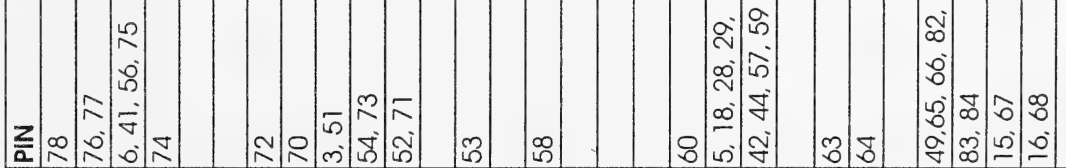
a

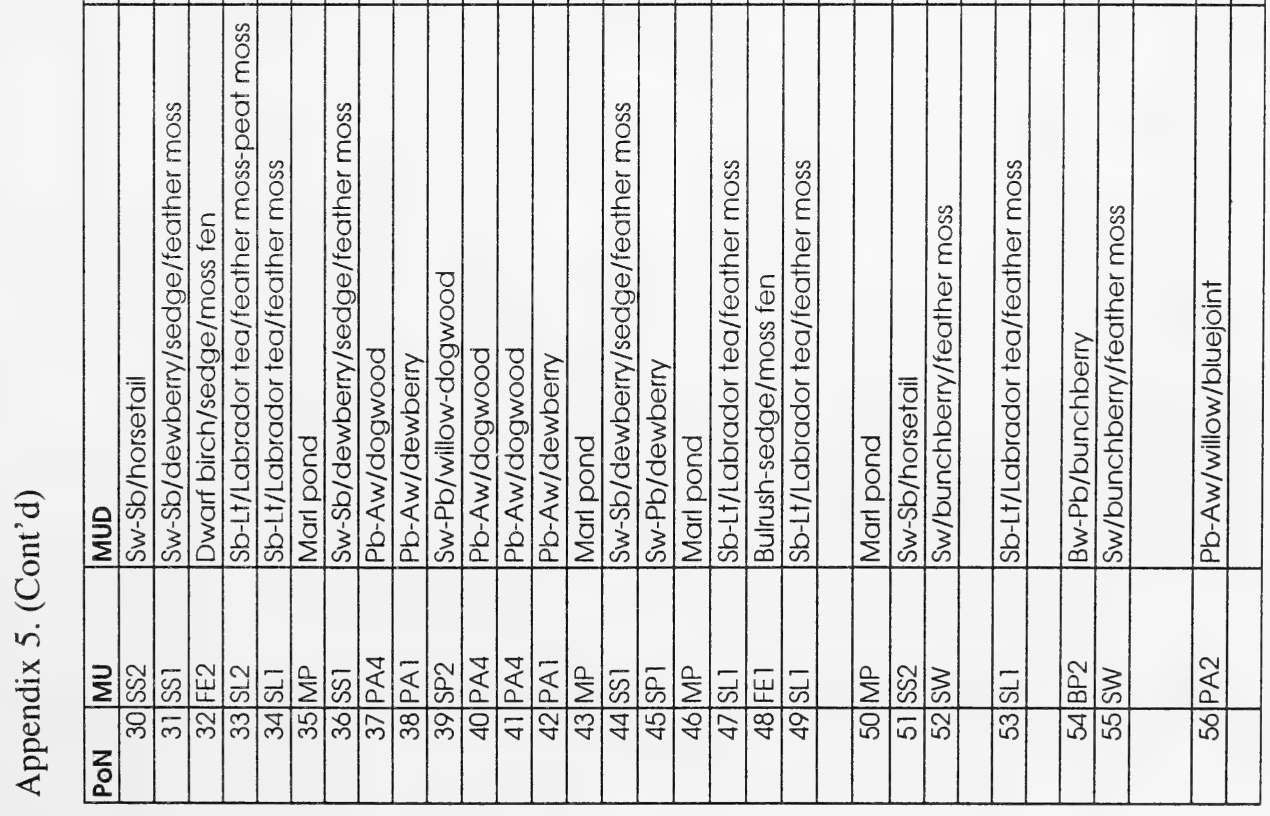





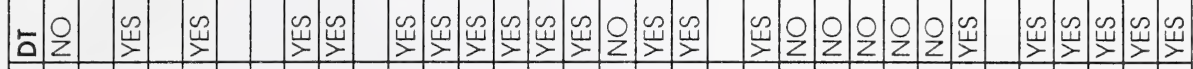

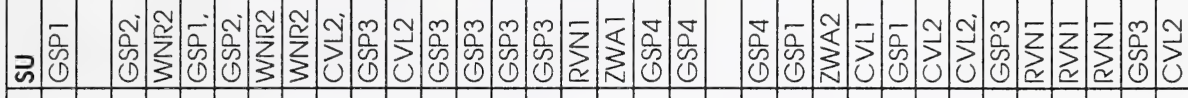

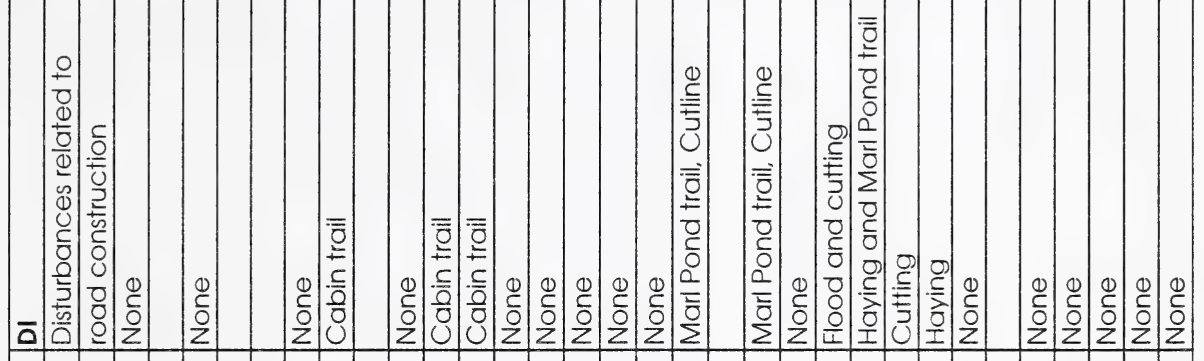

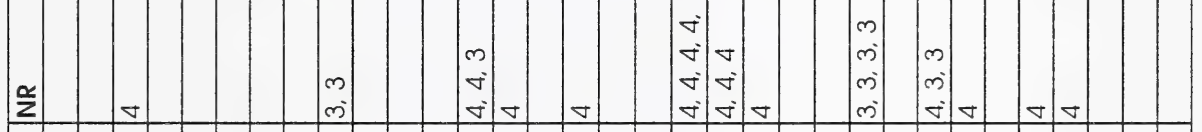

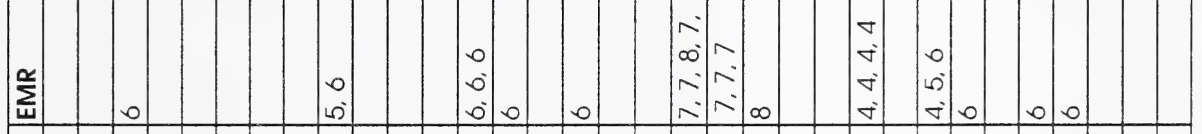

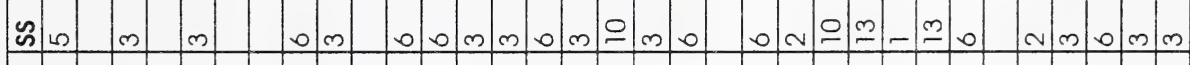

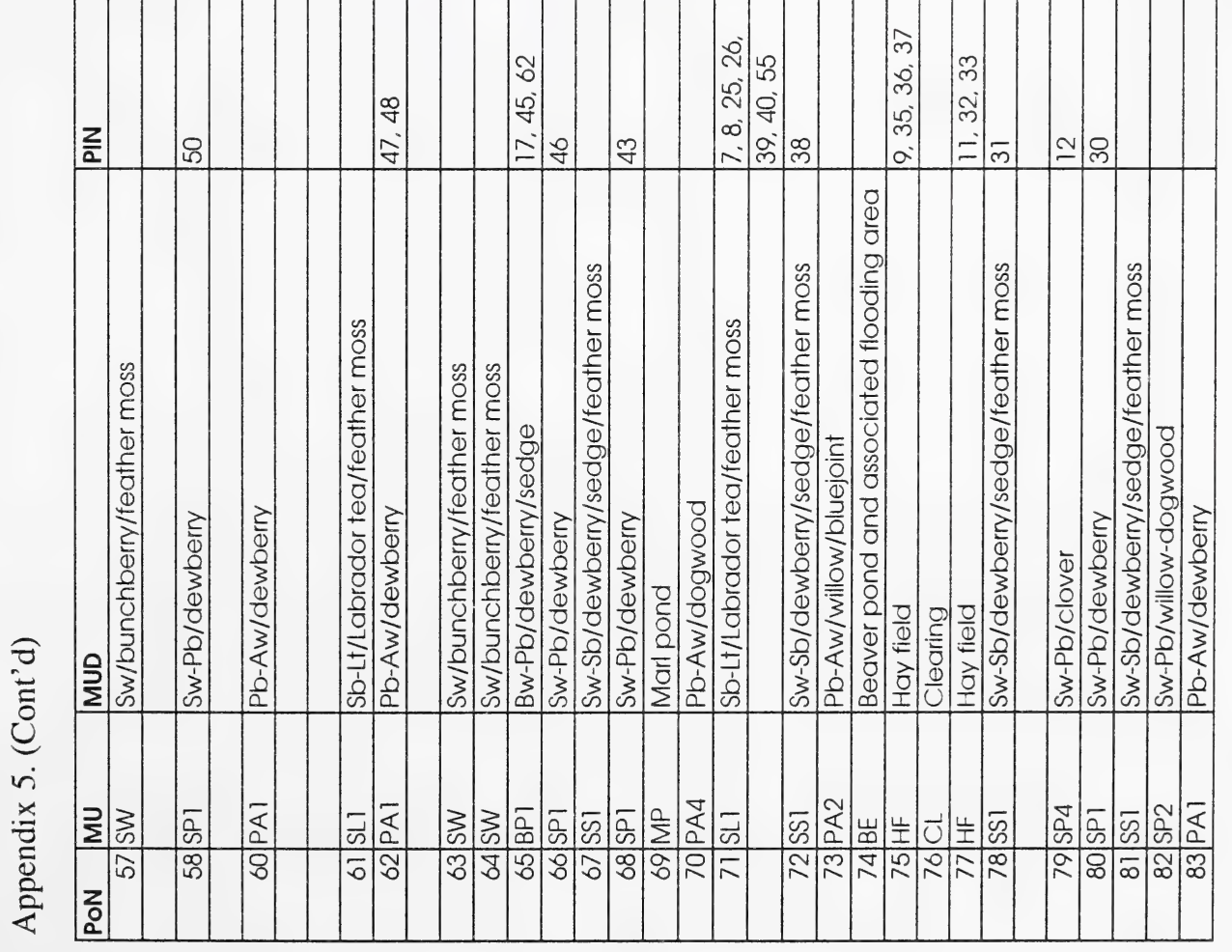





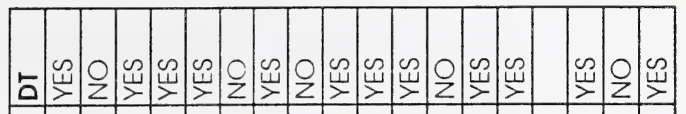

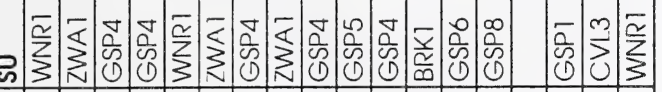

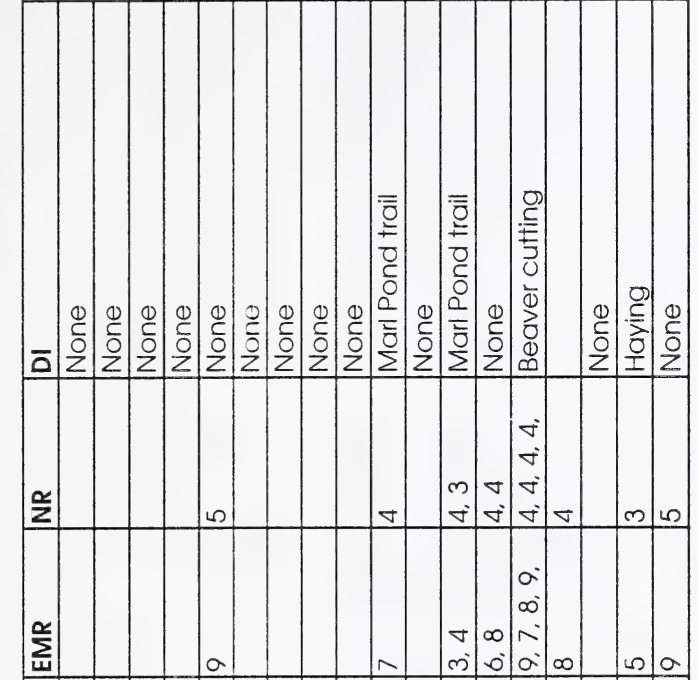

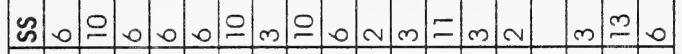

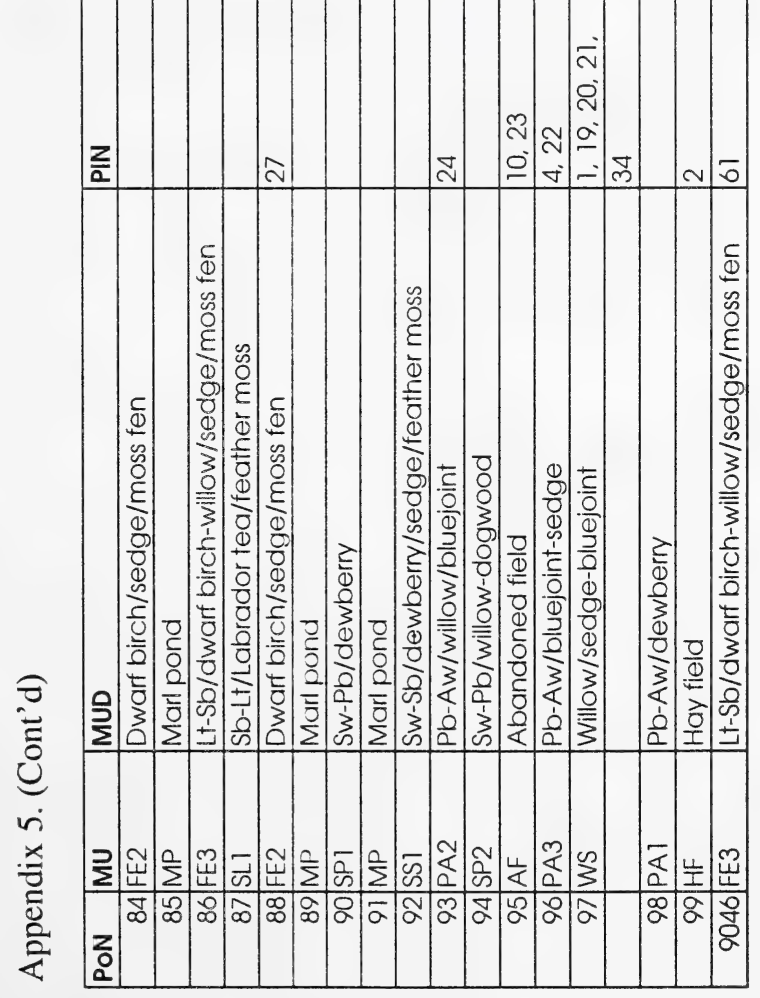





\section{Vegetation Polygon Attribute Legend}

\section{Title}

PoN

MU

MUD

PIN

SS

EMR

NR

DI

SU

DT

\section{Successional Status}

1

2

3

5

6

10

11

13

Ecological Moisture Regime 3

4

5

6

7

8

9

\section{Nutrient Regime}

3

4

5
Polygon Number

Map Unit

Map Unit Description

Plot Number

Successional Status

Ecological Moisture Regime

Nutrient Regime

Disturbances

Dominant/Co-dominant Soil Unit

Dead Timber

Pioneer Seral

Young Seral

Mature Seral

Young Edaphic Climax

Mature Edaphic Climax

Non-vegetated

Old Field

Cultivated Pasture

Subxeric (moderately dry)

Submesic (moderately fresh)

Mesic (fresh)

Subhygric (moderately moist)

Hygric (moist)

Subhydric (moderately wet)

Hydric (wet)

Mesotrophic (medium)

Permesotrophic (medium)

Eutrophic (rich)

\section{Soil Unit}

For soil unit legend please refer to Appendix 4. 



\section{APPENDIX 6. \\ Vascular and Non-vascular Plant Species Recorded During Wagner Natural Area Study}



Appendix 6. Vascular and Non-vascular Plant Species Recorded During Wagner Natural Area study (for nomenclature, see section 3.3.4 of the report).

Scientific name

Vascular plants

Acer negundo L.

Achillea millefolium L. ssp. lanulosa (Nutt.) Piper

Achillea sibirica Ledeb.

Actaea rubra (Ait.) Willd.

Adoxa moschatellina L.

Agropyron repens (L.) Beauv.

Agropyron trachycaulum (Linke) Malte

Alnus tenuifolia Nutt.

Amelanchier alnifolia Nutt.

Andromeda polifolia L.

Antennaria parvifolia Nutt.

Aralia nudicaulis L.

Aster borealis (T. \& G.) Prov.

Aster cillolatus Lindl.

Aster conspicuus Lindl.

Aster hesperius A. Gray

Aster puniceus L.

Betula neoalaskana Sargent

Betula pumila L. var. glandulifera Regal

Bromus ciliatus L.

Bromus inermis Leyss.ssp. inermis

Calamogrostis canadensis (Michx.) Beauv.

Calamogrostis inexpansa A. Gray

Caltha palustris $\mathrm{L}$.

Carex aquatilis Wahlenb.

Carex atherodes Spreng.

Carex aurea Nutt.

Carex bebbii OIney ex Fern.

Carex capillaris L.

Carex concinna R. Br.

Carex deweyana Schwein.

Carex diandra Schrank

Carex disperma Dewey

Carex gynocrates Wormsk.

Carex interior Bailey

Carex leptalea Wahlenb.

Carex limosa L.

Carex livida (Wahlenb.) Will.

Carex norvegica Retz.

Carex peckii Howe

Carex prairea Dewey

Carex sartwellii Dewey

Carex stipata Muhl. ex Willd.
Common name

CODES

\begin{tabular}{|c|c|}
\hline Manitoba maple & ACERNEG \\
\hline common yarrow & ACHIMILL \\
\hline northern yarrow & ACHISIB \\
\hline red and white baneberry & ACTARUB \\
\hline moschatel & ADOXMOS \\
\hline quack grass & AGROREP \\
\hline slender wheat grass & AGROTRA \\
\hline river alder & ALNUTEN \\
\hline saskatoon & AMELALN \\
\hline bog rosemary & ANDRPOL \\
\hline small-leaved everlasting & ANTEPAR \\
\hline wild sarsaparilla & ARALNUD \\
\hline marsh aster & ASTEBOR \\
\hline Lindley's aster & ASTECIL \\
\hline showy aster & ASTECON \\
\hline western willow aster & ASTEHES \\
\hline purple-stemmed aster & ASTEPUN \\
\hline Alaska birch & BETUNEO \\
\hline dwarf birch & BETUPUM \\
\hline fringed brome & BROMCIL \\
\hline awnless brome & BROMINE \\
\hline bluejoint & CALACAN \\
\hline northern reed grass & CALAINE \\
\hline marsh marigold & CALTPAL \\
\hline water sedge & CAREAQU \\
\hline awned sedge & CAREATH \\
\hline golden sedge & CAREAUR \\
\hline Bebb's sedge & CAREBEB \\
\hline hair-like sedge & CARECAP \\
\hline beautiful sedge & CARECON \\
\hline Dewey's sedge & CAREDEW \\
\hline two-stamened sedge & CAREDIA \\
\hline two-seeded sedge & CAREDIS \\
\hline northern bog sedge & CAREGYN \\
\hline inland Sedge & CAREINT \\
\hline bristle-stalked sedge & CARELEP \\
\hline mud sedge & CARELIM \\
\hline livid sedge & CARELIV \\
\hline Norway sedge & CARENOR \\
\hline Peck's sedge & CAREPEC \\
\hline prairie Sedge & CAREPRA \\
\hline Sartwell's sedge & CARESAR \\
\hline awl-fruited sedge & CARESTI \\
\hline
\end{tabular}


Appendix 6. (Cont'd)

Carex utriculata Boott

Carex vaginata Tausch

Carex viridula Michx.

Cicuta maculata L.

Cinna latifolia (Trev.) Griesb

Circaea alpina $L$.

Cirsium arvense (L.) Scop.

Corallorhiza trifida Chatelain

Cornus canadensis L.

Cornus stolonifera Michx.

Crepis runcinata (James) T. \& G.

Cypripedium calceolus L.

Deschampsia cespitosa (L.) Beauv.

Dodecatheon pulchellum (Raf.) Merr.

Drosera anglica Huds.

Drosera rotundifolia L.

Dryopteris carthusiana (Vill.) H.P. Fuchs

Empetrum nigrum L.

Epilobium angustifolium L.

Epilobium ciliatum Raf.

Epilobium leptophyllum Raf.

Epilobium palustre $L$.

Equisetum arvense L.

Equisetum fluviatile L.

Equisetum palustre $L$.

Equisetum pratense Ehrh.

Equisetum scirpoides Michx.

Erigeron philadelphicus $\mathrm{L}$.

Eriophorum polystachion L.

Festuca rubra L.

Fragaria vesca L.

Fragaria virginiana Duchesne ssp. glauca

Galeopsis tetrahit L.

Galium boreale L.

Galium labradoricum Wieg.

Galium trifidum L.

Galium triflorum Michx.

Geocaulon lividum (Richards.) Fern.

Geum aleppicum Jacq.

Geum rivale L.

Glyceria striata (Lam.) Hitchc.

Goodyera repens (L.) R. Br.

Habenaria dilatata (Pursh) Hook.

Habenaria hyperborea (L.) R. Br.

Habenaria obtusata (Pursh) Richards.

Heracleum lanatum Michx.

Hieracium umbellatum $\mathrm{L}$.

Impatiens capensis Meerb.

Juncus alpinoarticulatus Chaix small bottle sedge

CAREUTR

sheathed sedge

CAREVAG

green sedge

CAREVIR

water-hemlock

drooping wood reed

CICUMAC

small enchanter's nightshade

Canada thistle

pale coral-root

bunchberry

red-osier dogwood

scapose hawksbeard

yellow lady's -slipper

tufted hair grass

saline shooting-star

oblong-leaved sundew

round-leaved sundew

narrow spinulose shield fern

crowberry

common fireweed

northern willowherb

narrow-leaved willowherb

marsh willowherb

common horsetail

swamp horsetail

marsh horsetail

meadow horsetail

dwarf scouring-rush

Philadelphia fleabane

tall cotton-grass

red fescue

woodland strawberry

(S. Wats.) Staudt. wild strawberry

common hemp-nettle

northern bedstraw

Labrador bedstraw

small bedstraw

sweet-scented bedstraw

CINALAT

CIRCALP

CIRSARV

CORATRI

CORNCAN

CORNSTO

CREPRUN

CYPRCAL

DESCCES

DODEPUL

DROSANG

DROSROT

DRYOCAR

EMPENIG

EPILANG

EPILCIL

EPILLET

EPILPAL

EQUIARV

EQUIFLU

EQUIPAL

EQUIPRA

EQUISCI

ERIGPHI

ERIOPOL

FESTRUB

FRAGVES

FRAGVIR

GALETET

GALIBOR

GALILAB

GALITRF

GALITRI

GEOCLIV

GEUMALE

GEUMRIV

GLYCSTR

GOODREP

HABEDIL

HABEHYP

HABEOBT

HERALAN

HIERUMB

IMPACAP

JUNCALP 

Appendix 6. (Cont'd)

Juncus balticus Willd.

wire rush

JUNCBAL

Juncus tenuis Willd. var. dudleyi (Wieg.) Hermann

Dudley's slender rush

JUNCTEN

(Specimen sent for identification)

KBOOOO

Larix laricina (DuRoi) K. Koch

tamarack

LARILAR

Lathyrus ochroleucus Hook.

cream-colored vetchling

LATHOCH

Ledum groenlandicum Oeder

common Labrador tea

LEDUGRO

Lemna minor $L$.

Lilium philadelphicum L. var andinum (Nutt.) Ker

Linnaea borealis L. ssp. americana (Forbes) Hult.

Listera cordata (L.) R. Br.

Lobelia kalmii L.

Lonicera dioica L.

Lonicera involucrata (Richards.) Banks

Lysimachia thyrsiflora L.

Maianthemum canadense Desf. var. interius Fern

Malaxis monophylla (L.) Sw.

Medicago sativa L.

Melilotus alba Desr.

Mentha arvensis $\mathrm{L}$.

Mertensia paniculata (Ait.) G. Don

Mitella nuda L.

Moehringia lateriflora (L.) Fenzl.

Moneses uniflora (L.) A. Gray

Muhlenbergia glomerata (Willd.) Trin.

Orchis rotundifolia Banks ex Pursh

Orthilia secunda (L.) House

Oxycoccus microcarpus Turcz.

Oxycoccus quadripetalus Gilib.

Parnassia palustris L. var. neogaea Fern.

Pedicularis groenlandica Retz.

Petasites palmatus (Ait.) A. Gray

Petasites sagittatus (Pursh) A. Gray

Phalaris arundinacea $\mathrm{L}$.

Phleum pratense $\mathrm{L}$.

Picea glauca (Moench) Voss

Picea mariana (Mill.) BSP

Pinguicula vulgaris $L$.

Poa interior Rydb.

Poa palustris $L$.

Poa pratensis $\mathrm{L}$.

Populus balsamifera L.

common duckweed

LEMNMIN

western wood lily

LILIPHI

twin-flower

LINNBOR

heart-leaved twayblade

LISTCOR

Kalm's lobelia

LOBEKAL

twining honeysuckle

LONIDIO

bracted honeysuckle

LONIINV

tufted loosestrife

LYSITHY

wild lily-of-the-valley

MAIACAN

white adder's-mouth

MALAMON

alfalfa

MEDISAT

white sweet clover

MELIALB

wild mint

MENTARV

tall lungwort

MERTPAN

bishop's-cap

MITENUD

blunt-leaved sandwort

MOEHLAT

one-flowered wintergreen

MONEUNI

bog muhly

round-leaved orchid

MUHLGLO

one-sided wintergreen

ORCHROT

ORTHSEC

small bog cranberry

OXYCMIC

small bog cranberry

OXYCQUA

northern grass-of-Parnassus

PARNPAL

Elephant's-head

PEDIGRO

palmate-leaved coltsfoot

PETAPAL

arrow-leaved coltsfoot

PETASAG

reed canary grass

PHALARU

timothy

PHLEPRA

white spruce

PICEGLA

black spruce

PICEMAR

common butterwort

PINGVUL

inland bluegrass

POAINTE

fowl bluegrass

Kentucky bluegrass

POAPALU

POAPRAT

balsam poplar

POPUBAL

aspen

POPUTRE

silverweed

POTEANS

common pink wintergreen

PYROASA

seaside buttercup

RANUCYM

yellow water crowfoot

RANUGME

Lapland buttercup

RANULAP

celery-leaved buttercup

RANUSCE

wild black currant

RIBEAME

skunk currant

RIBEGLA 

Appendix 6. (Cont'd)

Ribes hudsonianum Richards.

Ribes lacustre (Pers.) Poir.

Ribes oxyacanthoides L.

Ribes triste Pall.

Rorippa palustris (L.) Basser ssp. palustris

Rosa acicularis Lindl.

Rosa woodsii Lindl.

Rubus arcticus L. ssp acaulis (Michx.) Focke

Rubus idaeus L.

Rubus pubescens Raf.

Rumex occidentalis S. Wats.

Salix athabascensis Raup

Salix bebbiana Sarg.

Salix candida Fluegge ex Willd.

Salix discolor Muhl.

Salix lucida Muhl.

Salix maccalliana Rowlee

Salix myrtillifolia Anderss.

Salix petiolaris J. E. Smith

Salix planifolia Pursh

Salix pseudomonticola Ball

Salix pyrifolia Anderss.

Salix spp.

Schizachne purpurascens (Torr.) Swallen

Scirpus acutus Muhl. ex Bigel.

Scirpus cespitosus L. var. callosus Bigel.

Scirpus pungens Vahl ssp. pungens

Scutellaria galericulata L.

Senecio eremophilus Richards.

Senecio pauperculus Michx.

Shepherdia canadensis (L.) Nutt.

Smilacina stellata (L.) Desf.

Smilacina trifolia (L.) Desf.

Solidago canadensis $\mathrm{L}$.

Solidago gigantea Ait.

Sonchus uliginosus Bieb.

Sorbus aucuparia L.

Sphenopholis intermedia (Rydb.) Rydb.

Stellaria longifolia Muhl.

Stellaria media (L.) Cyrill.

Symphoricarpos albus (L.) Blake

Symphoricarpos occidentalis Hook.

Taraxacum officinale Weber

Tofieldia glutinosa (Michx.) Pers.

Trifolium hybridum $\mathrm{L}$.

Trifolium pratense $\mathrm{L}$.

Trifolium repens $\mathrm{L}$.

Triglochin maritima L.

Triglochin palustris $\mathrm{L}$.

Typha latifolia L. northern black currant

RIBEHUD

bristly black currant

northern gooseberry

wild red currant

marsh yellow cress

prickly rose

common wild rose

dwarf raspberry

wild red raspberry

dewberry

western dock

Athabasca willow

beaked willow

hoary willow

pussy willow

shinning willow

velvet-fruited willow

myrtle-leaved willow

basket willow

flat-leaved willow

false mountain willow

balsam willow

willows

purple oat grass

great bulrush

tufted buirush

three-square bulrush

marsh skullcap

cut-leaved ragwort

balsam groundsel

Canada buffaloberry

star-flowered Solomon's-seal

three-leaved Solomon's-seal

Canada goldenrod

late goldenrod

smooth perennial sow-thistle

European mountain-ash

slender wedge grass

long-leaved chickweed

common chickweed

snowberry

buckbrush

common dandelion

sticky false asphodel

alsike clover

red clover

white clover

seaside arrow-grass

slender arrow-grass

common cattail
RIBELAC

RIBEOXY

RIBETRI

RORIPAL

ROSAACI

ROSAWOO

RUBUARC

RUBUIDE

RUBUPUB

RUMEOCC

SALIATH

SALIBEB

SALICAN

SALIDIS

SALILUC

SALIMAC

SALIMYR

SALIPET

SALIPLA

SALIPSE

SALIPYR

SALISPP

SCHIPUR

SCIRACU

SCIRCES

SCIRPUN

SCUTGAL

SENEERE

SENEPAP

SHEPCAN

SMILSTE

SMILTRI

SOLICAN

SOLIGIG

SONCULI

SORBAUC

SPHEINT

STELLON

STELMED

SYMPALB

SYMPOCC

TARAOFF

TOFIGLU

TRIFHYB

TRIFPRA

TRIFREP

TRIGMAR

TRIGPAL

TYPHLAT 

Appendix 6. (Cont'd)

Urtica dioica L. ssp. gracilis (Ait.) Selander

Utricularia intermedia Hayne

Vaccinium myrtilloides Michx.

Vaccinium vitis-idaea L. ssp. minus (Lodd.) Hult

Valeriana dioica L. ssp. sylvatica (Rich.) F.G. Mey.

Viburnum edule (Michx.) Raf.

Vicia americana Muhl.

Viola canadensis L. var. rugulosa (Greene) C.L. Hitchc.

Viola nephrophylla Greene

Viola renifolia A. Gray

Viola selkirkii Pursh

\section{Mosses}

Aulacomnium palustre (Hedw.) Schwaegr.

Brachythecium campestre (C. Mull.) B.S.G.

Brachythecium mildeanum (Schimp.) Schimp. in Milde

Brachythecium salebrosum (Web. \& Mohr) B.S.G.

Brachythecium spp.

Brachythecium starkei (Brid.) Schimp. in B.S.G.

Brachythecium turgidum (C.J. Hartm.) Kindb.

Bryum pseudotriquetrum (Hedw.) Gartn.

Calliergon giganteum (Schimp.) Kindb.

Campylium stellatum (Hedw.) C. Jens.

Catoscopium nigritum (Hedw.) Brid.

Dicranum elongatum Schleich

Dicranum fragilifolium Lindb.

Dicranum polysetum Sw.

Dicranum undulatum Brid.

Drepanocladus aduncus (Hedw.) Warnst.

Drepanocladus revolvens (Sw.) Warnst.

Drepanocladus vernicosus (Lindb. ex C. hartm.) Warnst.

Eurhynchium pulchellum (Hedw.) Jenn.

Helodium blandowii (Web. and Mohr) Warnst.

Hylocomium splendens (Hedw.) B.S.G.

Hypnum lindbergii Mitt.

Meesia triquetra (Risht.) Angstr.

Mnium spinulosum B.S.G.

Plagiomnium cuspidatum (Hedw.) Kop.

Plagiomnium ellipticum (Brid.) Kop.

Pleurozium schreberi (Brid.) Mitt.

Polytrichum strictum Brid.

Ptilium crista-castrensis (Hedw.) De Not.

Rhizomnium pseudopunctatum (Bruch and Schimp.) Kop.

Rhytidiadelphus triquetrus (Hedw.) Warnst.

Scorpidium scorpioides (Hedw.) Limpr.

Scorpidium turgescens ( $T$. Jens.) Loeske

Sphagnum capillifolium (Ehrh.) Hedw.

Sphagnum fuscum (Schimp.) Klinggr.

Sphagnum warnstorfii Russ. common nettle

URTIDIO

flat-leaved bladderwort

UTRIINT

blueberry

bog cranberry

VACCMYR

VACCVIT

VALEDIO

VIBUEDU

VICIAME

VIOLCAN

VIOLNEP

VIOLREN

VIOLSEL

tufted moss

AULAPAL

BRACCAM

BRACMIL

BRACSAL

BRACSPP

BRACSTA

BRACTUR

BRYUPSE

CALLGIG

CAMPSTE

CATONIG

long forked moss

DICRELO

cushion moss

DICRFRA

wavy dicranum

DICRPOL

wavy dicranum

DICRUND

brown moss

DREPADU

brown moss

brown moss

DREPREV

DREPVER

EURHPUL

HELOBLA

stair-step moss

HYLOSPL

HYPNLIN

MEESTRI

MNIUSPI

PLAGCUS

PLAGELL

Schreber's moss

PLEUSCH

POLYSTR

PTILCRI

RHIZPSE

red-stemmed pipecleaner

RHYTTRI

SCORSCO

SCORTUR

acute-leaved peat moss

SPHACAP

SPHAFUS

SPHAWAR 

Appendix 6. (Cont'd)

Thuidium recognitum (Hedw.) Lindb.

THUIREC

Tomenthypnum nitens (Hedw.) Loeske

golden moss

TOMENIT

Liverworts

Marchantia polymorpha $L$.

Plagiochila asplenoides (L.) Dum

liverwort

MARCPOL

liverwort

PLAGASP

\section{Lichens}

Cladina arbuscula (Wallr.) Hale \& W. Culb.

reindeer lichen

CLADARB

Cladina mitis (Sandst.) Hale \& W. Culb.

reindeer lichen

CLADMIT

Cladina rangiferina (L.) Harm.

Cladonia chlorophaea (Floerke ex Somm.) Spreng.

reindeer lichen

CLADRAN

CLADCHL

CLADCON

Cladonia coniocraea (Floerke) Spreng.

CLADCOR

Cladonia cornuta (L.) Hoffm.

CLADCRI

Cladonia crispata (Ach.) Flot.

CLADFUR

Cladonia furcata (Huds.) Schrad.

CLADGRA

Cladonia gracilis (L.) Willd.

CLADPLE

Cladonia pleurota (Florke) Schaer.

CLADSCA

Cladonia scabriuscula (Del. ex Duby) Nyl.

PELTAPH

Peltigera aphthosa L. Willd.

studded leather lichen

PELTCAN 



\section{APPENDIX 7 \\ Wagner Natural Area: Vascular Plant List}



Appendix 7: Wagner Natural Area: Vascular Plant List

(based on a compilation by Julie O. Hrapko in "Natural History Information No. 88. December 1991.

Alberta Culture and Multiculturalism, Provincial Museum of Alberta, Edmonton)

Key to columns:

Column 1. Scientific name and authority: Nomenclature is largely according to E.H. Moss, 1983, Flora of Alberta, 2d ed., rev. by J.G. Packer, University of Toronto Press.

$\mathrm{R}=$ rare species in Alberta

$\mathrm{X}=$ extirpated (extinct at site) or no record in at least 15 years

$\mathrm{I}=$ Introduced (not native to Alberta)

$\mathrm{G}=$ garden or landscaping plant escaped from cultivation

$?=$ incomplete information for the species

Column 2. Common names are according to Ealey, D. 1992. Alberta plants and fungi-master species list and species group checklists, Alberta Energy, Forestry, Lands \& Wildlife, Edmonton.

Column 3. Flowering times. Based on Wagner Natural Area Society's knowledge of the site's flora, as compiled by Pat McIsaac and Chel Macdonald (with assistance from Alberta Culture and Multiculturalism) for Alberta's Watchable Wildlife Checklist Series: Wagner Natural Area - Plants. (N.D.)
1. early spring (late March to early May)
2. late spring (mid-May to end of June)

3. summer (July)

$\mathrm{NA}=$ plant does not produce flowers/seeds (e.g. ferns)

4. late summer (August to killing frost)

Column 4. Abundance at the Site. Coding developed for Alberta's Watchable Wildlife Checklist Series by Pat McIsaac and Chel Macdonald and assigned according to Wagner Natural Area Society's knowledge of the flora.

C common (usually present in most identified habitats)

$\mathrm{U}$ uncommon (seldom present in identified habitats)

0 occasional (almost never present in the identified habitats)

$\mathrm{P}$ present in unknown numbers

Column 5. Habitat. Coding developed for Alberta's Watchable Wildlife Checklist Series by Pat McIsaac and Chel Macdonald and assigned (with slight modifications) according to Wagner Natural Area Society's knowledge of the flora.

$\mathrm{Pea}=$ peatland ( marl ponds; peat/brown mosses dominate )

Wet $=$ wet areas other than peatland

$\mathrm{Gra}=$ grassland ( forbs and grasslike plants dominate )

Shr $=$ shrubland $($ tall shrubs $[>0.5 \mathrm{~m}]$ dominate $)$

Con $=$ coniferous (needle-leaved) tree forest

$\mathrm{Brl}=$ broad-leaved tree forest

Mix $=$ mixedwood (mixed coniferous \& broad-leaved forest)

For $=$ forest (present in most or all of the forest types)

Dis $=$ disturbed (bare soil dominates)

$\mathrm{Pea}=$ peatland ( marl ponds; peat/brown mosses dominate )

Wet $=$ wet areas other than peatland

$\mathrm{Gra}=$ grassland ( forbs and grasslike plants dominate )

$\mathrm{Shr}=$ shrubland $($ tall shrubs $[>0.5 \mathrm{~m}]$ dominate $)$

Con $=$ coniferous (needle-leaved) tree forest

$\mathrm{Brl}=$ broad-leaved tree forest

Mix $=$ mixedwood (mixed coniferous \& broad-leaved forest)

For $=$ forest (present in most or all of the forest types)

Dis disturbed (bare soil dominates)

Various $=$ present in various habitats except open water 

Scientific name \& authority

LYCOPODIACEAE

Lycopodium annotinum $\mathrm{L}$.

\section{EQUISETACEAE}

Equisetum arvense $\mathrm{L}$.

E. fluviatile L.

E. palustre L.

E. pratense Ehrh.

E. scirpoides Michx.

E. variegatum Schleich.

\section{OPHIOGLOSSACEAE}

Botrychium virginianum (L.) Sw.

\section{POLYPODIACEAE}

Dryopteris carthusiana (Vill.)

H.P. Fuchs

Gymnocarpium dryopteris (L.)

Newm.

\section{PINACEAE}

Larix laricina (DuRoi) K. Koch

Picea glauca (Moench) Voss

P. mariana (Mill.) BSP

\section{TYPHACEAE}

Typha latifolia $\mathrm{L}$.

SPARGANIACEAE

Sparganium angustifolium Michx.

POTAMOGETONACEAE

Potamogeton filiformis Pers.

JUNCAGINACEAE

Triglochin maritima $\mathrm{L}$.

T. palustris L.

\section{ALISMATACEAE}

Alisma plantago-aquatica L.

\section{Common name}

Club-moss Family

stiff club-moss

Horsetail Family

common horsetail

swamp horsetail

marsh horsetail

meadow horsetail

dwarf scouring-rush

variegated horsetail

Adder's-tongue Family

Virginia grape fern

NA

NA

NA

NA

NA

NA

NA

\section{Fern Family}

narrow spinulose shield

fern

oak fern

\section{Pine Family}

tamarack, American

larch

white spruce

black spruce

\section{Cattail Family}

common cattail

Bur-reed Family

narrow-leaved bur-reed

3-4

Pondweed Family

thread-leaved pondweed

3

2-4

2-3

slender arrow-grass

Arrow-grass Family

seaside arrow-grass

Water-plantain Family

broad-leaved water

plantain

3

NA

NA

NA

$2-3$
Flowering Abundance Habitat Period

$\mathrm{O}$

Con

U

C

C

Pea; Con

Con; Mix

Pea; Con

C

Wet; Pea

Wet

C Wet

\section{Grass Family}

GRAMINEAE (POACEAE)

Agropyron repens (L.) Beauv. A. trachycaulum (Linke) Malte Agrostis scabra Willd.

A. stolonifera L. quack grass

slender wheat grass hair grass, tickle grass

I redtop
For

For

Various

Wet

Wet

Con

Wet

Mix; /
Pea; Wet

Pea; Wet

O Wet

$\begin{array}{ll}\text { C } & \text { Gra; Dis } \\ \text { C } & \text { For; Gra } \\ \text { U } & \text { Pea; Wet } \\ \text { U } & \text { Wet-Dis }\end{array}$



Avena fatua $\mathrm{L}$ XI? wild oat

Beckmannia syzigachne (Steud.) slough grass 2-3

$P$

C

Gra-Dis

Fern.

Bromus ciliatus L.

fringed brome $2-3$

$2-3$

$B$. inermis Leyss. ssp. inermis I awnless brome 2-3

$2-3$

$B$. inermis ssp. pumpellianus

northern awnless brome

Wet

(Scribn.) Wagnon

Calamagrostis canadensis

(Michx.) Beauv.

C. inexpansa A. Gray

bluejoint; marsh reed

2

grass

northern reed grass

$2-3$

Festuca rubra L.

I red fescue

Glyceria grandis $\mathrm{S}$. Wats. ex Gray common tall manna grass

G. striata (Lam.) Hitchc.

fowl manna grass

3

Hierochloe odorata (L.) Beauv.

sweet grass

Koeleria macrantha (Ledeb.) J.A. june grass

Schultes f.

june grass $-2-3 \quad P$

Muhlenbergia glomerata (Willd.) bog muhly

Trin.

Phalaris arundinacea $\mathrm{L}$.

reed canary grass

$\mathrm{Brl}$

Phleum pratense $\mathrm{L}$.

Poa interior Rydb.

I timothy

? inland bluegrass

fowl bluegrass

$P$. palustris $\mathrm{L}$.

I? Kentucky bluegrass

P. pratensis $\mathrm{L}$.

slender salt-meadow

grass

Schizachne purpurascens (Torr.)

purple oat grass

C

$\mathrm{P}$

Gra; Dis

?

For; /; Pea

Pea

Gra

Wet

Pea; Wet;

Wet-For

Gra; Dis

Gra

Pea

Swallen

Scolochloa festucacea (Willd.)

spangletop

C

Wet; Wet-

Dis

Gra; Dis

Gra; For/

For; Wet;

Pea

2-3

Gra; Dis

Wet-Dis

2-3 C

For

3

U

Wet

Sphenopholis intermedia (Rydb.) slender wedge grass

3

Wet-Gra

Rydb.

\section{CYPERACEAE}

Carex aquatilis Wahlenb.

C. atherodes Spreng.

C. aurea Nutt.

C. bebbii Olney ex Fern.

C. brunnescens (Pers.) Poir. ?

C. capillaris $\mathrm{L}$.

C. concinna $\mathrm{R} . \mathrm{Br}$.

C. deweyana Schwein.

C. diandra Schrank

C. disperma Dewey

C. gynocrates Wormsk.

C. interior Bailey

C. lasiocarpa Ehrh. ssp.

americana D. Löve \& Bernard

C. leptalea Wahlenb.

C. limosa $\mathrm{L}$.

C. livida (Wahlenb.) Willd.

C. microptera Mack.

\section{Sedge Family}

water sedge

awned sedge

golden sedge

Bebb's sedge

brownish sedge

hair-like sedge

beautiful sedge

Dewey's sedge

two-stamened sedge

two-seeded sedge

Northern bog sedge

inland sedge

hairy-fruited sedge

bristle-stalked sedge

mud sedge

livid sedge

$1-2$

small-winged sedge
2
C

C

U

U

P

C

C

U

C

C

C

C

U

C

C

C

U
Wet

Wet

Wet; Pea

Wet

Pea; Con

Mix/; Pea

Con; Mix;

Pea

Mix

Pea

Con

Con; Pea

Pea

Pea; Wet

Con

Pea

Pea

For/ 


C. norvegica Retz.
C. paupercula Michx.
C. peckii Howe
C. prairea Dewey
C. sartwellii Dewey
C. siccata Dewey
C. stipata Muhl. ex Willd.
C. vaginata Tausch
C. viridula Michx.
C. utriculata Boott
Eleocharis tenuis (Willd.)
Schultes
E. palustris (L.) R. \& S.
E. quinqueflora (F.X. Hartm.)O.
Schwarz
Eriophorum polystachion L.
E. viridi-carinatum (Engelm.)
Fern.
Rhynchospora capillacea Torr. R Scirpus acutus Muhl. ex Bigel.
S. caespitosus L. var. callosus Bigel.
S. hudsonianus (Michx.) Fern.
S. microcarpus Presl
S. pungens Vahl ssp. pungens
S. validus Vahl
R

\section{JUNCACEAE}

Juncus alpinoarticulatus Chaix J. balticus Willd.

\section{J. bufonius L.}

$J$. longistylis Torr.

J. nodosus L.

J. tenuis Willd. var. dudleyi

(Wieg.) J. Hermann

\section{LILIACEAE}

Disporum trachycarpum

(S. Wats.) B. \& H.

Lilium philadelphicum L. var. andinum (Nutt.) Ker

Maianthemum canadense Desf. var. interius Fern.

Smilacina stellata (L.) Desf.

S. trifolia (L.) Desf.

Tofieldia glutinosa (Michx.) Pers.

\section{IRIDACEAE}

Sisyrinchium montanum Greene
Norway sedge

bog sedge

Peck's sedge

prairie sedge

Sartwell's sedge

hay sedge

awl-fruited sedge

sheathed sedge

green sedge

small bottle sedge

slender spike-rush

creeping spike-rush

few-flowered spike-rush

tall cotton-grass

thin-leaved cotton-grass

slender beak-rush

great bulrush

tufted bulrush

Hudson Bay bulrush

small-fruited bulrush

three-square bulrush

common great bulrush

\section{Rush Family}

alpine rush

wire rush

toad rush

long-styled rush

knotted rush

Dudley's slender rush
2

2-3

2-3

2-3

U
U
U
C
C

U

U

C

C

C

U

C

C

1-2

1-2

3-4

2-3

1-2

2

2-3

2

2-3

C

C

U

P

C

C

U

U

C

C

C

C

U

C

U
For/

Wet-Con

$\mathrm{Brl}$

Pea; Wet

Wet; Wet-

Shr

Gra/; For/

Wet

Con; Mix

Pea

Wet; Pea

Pea

Pea; Wet

Pea

Pea

Pea

Pea

Wet

Pea

Pea

Wet

Pea; Wet

Wet

Pea; Wet

Pea; Wet-

Gra

Wet-Dis

Pea

Pea; Wet

Pea

\section{Lily Family}

fairybells

U

Brl; Mix

western wood lily

wild lily-of-the-valley

$2-3$

C

For; Pea;

Gra

Mix

star-flowered Solomon's-

$2-3$

C

Mix; Pea

seal

three-leaved Solomon's-

2-3

C

Pea; Con

seal

sticky false asphodel

3

C

C

Pea

\section{Iris Family}

common blue-eyed grass 



\section{ORCHIDACEAE}

Calypso bulbosa (L.) Oakes

Corallorhiza maculata Raf.

C. trifida Chatelain

Cypripedium calceolus L. var. parviflorum (Salisb.) Fern.

C. passerinum Richards.

Goodyera repens (L.) R.Br.

Habenaria dilatata (Pursh) Hook.

H. hyperborea (L.) R. Br.

H. obtusata (Pursh) Richards.

H. orbiculata (Pursh) Torr.

H. viridis (L.) R.Br.

Listera cordata (L.) R.Br.

Malaxis monophylla (L.) Sw. R

M. paludosa (L.) Sw.

Orchis rotundifolia Banks ex

Pursh

Spiranthes romanzoffiana Cham.

$\&$ Schlecht.

\section{SALICACEAE}

Populus balsamifera L.

$P$. tremuloides Michx.

Salix athabascensis Raup

S. bebbiana Sarg.

S. brachycarpa Nutt.

$\mathrm{X}$ ?

$S$. candida Fluegge ex Willd.

S. discolor Muhl.

S. exigua Nutt.

S. lucida Muhl.

S. maccalliana Rowlee

S. myrtillifolia Anderss.

S. myrtillifolia Anderss. var. cordata (Anderss.) Dorn

S. petiolaris J.E. Smith

S. planifolia Pursh

S. pseudomonticola Ball

S. pyrifolia Anderss.

S. serissima (Bailey) Fern.

\section{BETULACEAE}

Alnus tenuifolia Nutt.

Betula neoalaskana Sarg.

B. pumila L. var. glandulifera

Regel

\section{URTICACEAE}

Urtica dioica L. ssp. gracilis (Ait.) Selander

\section{Orchid Family}

$\mathrm{X}$ ? Venus'-slipper

2

spotted coral-root

\section{$\mathrm{P}$}

Mix

pale coral-root

small yellow lady's-

Mix

slipper

sparrow's-egg lady's-

2-3

slipper

lesser rattlesnake

plantain

tall white bog orchid

northern green bog

orchid

blunt-leaved bog orchid

round-leaved bog orchid

bracted bog orchid

heart-leaved twayblade

white adder's-mouth

$\mathrm{R}$ bog adder's-mouth

round-leaved orchid

3-4

3

$2-3$

2-3

3

2-3

2-3

3

3-4

2-3

hooded ladies'-tresses

3-4

C

\section{Willow Family}

\begin{tabular}{|c|c|c|c|}
\hline balsam poplar & 1 & $\mathrm{C}$ & $\mathrm{Brl} ; \mathrm{Mix}$ \\
\hline aspen & 1 & $\mathrm{C}$ & $\mathrm{Brl} ; \mathrm{Mix}$ \\
\hline Athabasca willow & 1 & $\mathrm{C}$ & Pea \\
\hline beaked willow & $1-2$ & $\mathrm{C}$ & Shr; Brl \\
\hline short-capsuled willow & 1 & $\mathrm{P}$ & Pea \\
\hline hoary willow & 1 & $\mathrm{C}$ & Pea \\
\hline pussy willow & 1 & $\mathrm{U}$ & For/ \\
\hline sandbar willow & 2 & $\mathrm{U}$ & Shr; For/ \\
\hline shining willow & $1-2$ & $\mathrm{C}$ & Shr-Wet \\
\hline velvet-fruited willow & $1-2$ & $\mathrm{C}$ & Shr-Wet \\
\hline myrtle-leaved willow & 1 & $\mathrm{O}$ & Pea \\
\hline myrtle-leaved willow & 1 & $\mathrm{O}$ & $\begin{array}{l}\text { Pea; Con; } \\
\text { Gra }\end{array}$ \\
\hline basket willow & 1 & $\mathrm{C}$ & Shr \\
\hline flat-leaved willow & 1 & $\mathrm{C}$ & Shr-Wet \\
\hline false mountain willow & 1 & $\mathrm{C}$ & Shr; For/ \\
\hline balsam willow & 1 & $\mathrm{P}$ & Shr-Wet \\
\hline autumn willow & 2 & $\mathrm{C}$ & Shr-Wet \\
\hline \multicolumn{4}{|l|}{ Birch Family } \\
\hline river alder & 1 & $\mathrm{C}$ & Wet/ \\
\hline Alaska birch & 1 & $\mathrm{C}$ & Mix; Brl \\
\hline dwarf birch & 2 & $\mathrm{C}$ & Pea \\
\hline
\end{tabular}

\section{Nettle Family}

common nettle
Pea

Brl; Mix

For; Pea

$\mathrm{Brl}$; Mix

Con

Pea

Gra; For;

Pea

Con; Pea

Mix

Mix

Con; For/

Pea/; For/

Pea

Con; Pea

Brl; Mix

Shr; Brl

Pea

Pea

For/

Shr; For/

Shr-Wet

Shr-Wet

Pea

Pea; Con;

Gra

Shr-Wet

Shr; For/

Shr-Wet

Shr-Wet

Pea
$\mathrm{Brl}$; Dis 

SANTALACEAE

Geocaulon lividum (Richards.)

Fern.

\section{POLYGONACEAE}

Polygonum erectum $\mathrm{L}$. Rheum rhaponticum $\mathrm{L}$.

Rumex maritimus L.

$R$. occidentalis $\mathrm{S}$. Wats.

$R$. triangulivalvis (Dans.) Rech. f.

\section{CHENOPODIACEAE}

Chenopodium album $\mathrm{L}$.

C. capitatum (L.) Aschers.

\section{CARYOPHYLLACEAE}

Cerastium arvense $\mathrm{L}$.

$$
\text { C. vulgatum } \mathrm{L} \text {. }
$$

I

Moehringia lateriflora (L.) Fenzl. Stellaria calycantha (Ledeb.)

Bong.

S. crassifolia Ehrh.

S. longifolia Muhl.

S. longipes Goldie

S. media (L.) Cyrill.

\section{RANUNCULACEAE}

Actaea rubra (Ait.) Willd.

Anemone canadensis L.

A. riparia Fern.

Caltha palustris $\mathrm{L}$.

Delphinium glaucum S. Wats.

Ranunculus aquatilis $\mathrm{L}$.

$R$. cymbalaria Pursh

R. gmelinii DC.

$R$. lapponicus $\mathrm{L}$.

R. macounii Britt.

$R$. sceleratus $\mathrm{L}$.

Thalictrum dasycarpum Fisch. \& Ave.-Lall.

T. venulosum Trel.

FUMARIACEAE

Corydalis aurea Willd.

\section{CRUCIFERAE}

(BRASSICACEAE)

Arabis hirsuta (L.) Scop.

Armoracia rusticana Gaertn. IG

Capsella bursa-pastoris (L.)

\section{Sandalwood Family}

northern bastard toadflax $\quad 2-3$

C

Con

\section{Buckwheat Family}

striate knotweed

rhubarb

$2-4$

Dis

golden dock

$\mathrm{Brl}$

Wet-Dis;

Wet-Gra

western dock

2-3

Wet

narrow-leaved dock

$2-3$

Wet

\section{Goosefoot Family}

I lamb's-quarters

strawberry blite

Gra-Dis

Mix-Dis

\section{Pink Family}

field mouse-ear

chickweed

common mouse-ear 2

2

Gra

chickweed

blunt-leaved sandwort 2

northern stitchwort 2

fleshy stitchwort 2

long-leaved chickweed 2-3

U

long-stalked chickweed

$2-3$

common chickweed

2-4

Wet-Dis

Brl; Mix

Wet

P Wet

C Wet; Pea

U Brl; Gra

O Dis

\section{Crowfoot Family}

red and white baneberry

2

Canada anemone

tall anemone 2-3

marsh marigold $\quad 1-2$

tall larkspur 3

white water crowfoot $\quad 2-4$

creeping buttercup 2-3

yellow water crowfoot $\quad 2-4$

Lapland buttercup $\quad 2$

Macoun's buttercup 2-3

celery-leaved buttercup $\quad 2-3$

tall meadow rue

veiny meadow rue

$2-3$

$\mathrm{Brl}$; Mix

I; Shr; Brl

For/

Wet

Brl; Mix

Wet

Wet

Wet

Pea

Wet; Brl

Wet

/; Brl

\section{Fumitory Family}

golden corydalis

U

Dis

\section{Mustard Family}

hairy rock cress

$2-3$

horse-radish

2

shepherd's-purse
I

Mix/; Dis

Dis 

Medic.

Cardamine pensylvanica Muhl.

Draba nemorosa L.

bitter cress

2-3

2

wow-grass

wormseed mustard

yellow cress

Rorippa palustris (L.) Besser ssp. palustris

\section{DROSERACEAE}

Drosera anglica Huds.

$$
\text { D. rotundifolia } \mathrm{L} \text {. }
$$

\section{SAXIFRAGACEAE}

Chrysosplenium iowense Rydb.

Mitella nuda L.

\section{PARNASSIACEAE}

Parnassia palustris L. var. neogaea Fern.

\section{GROSSULARIACEAE}

Ribes americanum Mill.

R. glandulosum Grauer

R. hirtellum Michx.

$R$. hudsonianum Richards.

$R$. lacustre (Pers.) Poir.

$R$. oxyacanthoides $\mathrm{L}$.

$R$. triste Pall.

\section{ROSACEAE}

Agrimonia striata Michx. Amelanchier alnifolia Nutt.

Cotoneaster sp.

Fragaria vesca $\mathrm{L}$.

$F$. virginiana Duchesne ssp. glauca (S. Wats.) Staudt.

Geum aleppicum Jacq.

G. macrophyllum Willd. ssp.

perincisum (Rydb.) Hult.

G. rivale L.

Malus baccata Borkh. var.

mandshurica Schneid.

Potentilla anserina L.

$P$. arguta Pursh

P. palustris (L.) Scop.

Prunus virginiana $\mathrm{L}$.

Rosa acicularis Lindl.

$R$. woodsii Lindl.

Rubus arcticus L. ssp. acaulis

(Michx.) Focke
$R$. idaeus $\mathrm{L}$.
$R$. pubescens $\mathrm{Raf}$.

\section{Sundew Family}

oblong-leaved sundew $3 \quad$ C $\quad$ Pea

round-leaved sundew 3

C

Pea

\section{Saxifrage Family}

golden saxifrage

bishop's-cap

2

$2-3$

U

C

Wet-For

For

\section{Grass-of-Parnassus \\ Family}

northern grass-of-

Parnassus

Wet;Pea

\section{Currant \& Gooseberry}

\section{Family}

wild black currant

skunk currant

2

1-2

C

Brl; Mix

wild gooseberry

1-2

northern black currant

bristly black currant

northern gooseberry

wild red currant

Con-Wet;

Brl-Wet

For/

For-Wet

Con; Mix

$\mathrm{Brl}$; Brl/

For

\section{Rose Family}

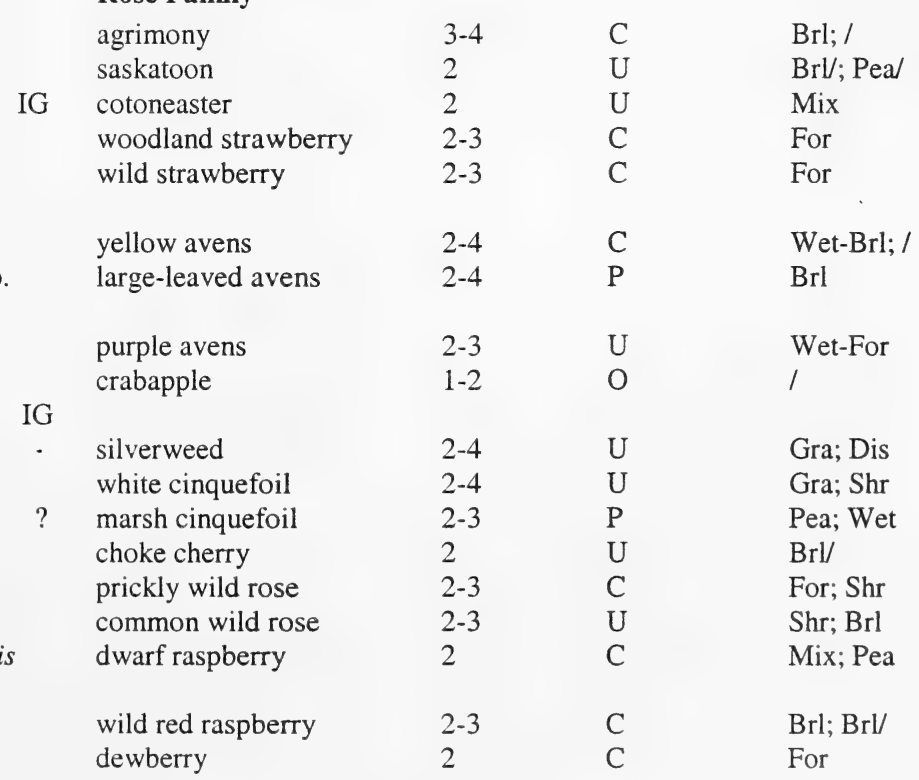





\section{LEGUMINOSAE \\ (FABACEAE) \\ Lathyrus ochroleucus Hook. \\ Medicago falcata $\mathrm{L}$. \\ M. lupulina $\mathrm{L}$. \\ M. sativa $\mathrm{L}$. \\ Melilotus alba Desr. \\ M. officinalis (L.) Lam. \\ Trifolium hybridum $\mathrm{L}$. \\ T. pratense $\mathrm{L}$. \\ T. repens $\mathrm{L}$.}

\section{GERANIACEAE}

Geranium bicknellii Britt.

G. richardsonii Fisch. \& Trautv.

\section{EMPETRACEAE}

Empetrum nigrum $\mathrm{L}$.

\section{ACERACEAE}

Acer negundo L.

\section{BALSAMINACEAE}

Impatiens capensis Meerb.

\author{
VIOLACEAE \\ Viola adunca J.E. Smith \\ $V$. canadensis $L$. var. rugulosa \\ (Greene) C.L. Hitchc. \\ $V$. nephrophylla Greene \\ $V$. palustris L. \\ $V$. renifolia A. Gray \\ V. selkirkii Pursh
}

\section{ELAEAGNACEAE}

Shepherdia canadensis (L.) Nutt.

\section{ONAGRACEAE}

Circaea alpina L.

Epilobium angustifolium $L$.

E. ciliatum Raf. ssp.

glandulosum (Lehm.) Hoch \&

Raven
E. leptophyllm Raf.

HIPPURIDACEAE

Hippuris vulgaris $\mathrm{L}$.

\section{Pea Family}

cream-colored vetchling $\quad 2-3$

\section{Geranium Family}

Bicknell's geranium

Dis wild white geranium

\section{Crowberry Family}

crowberry

Pea

\section{Maple Family}

I Manitoba maple

1

$\mathrm{Brl} ; \mathrm{Brl} /$

\section{Touch-me-not Family}

spotted touch-me-not

Wet

\section{Violet Family}

early blue violet

Gra; /

western Canada violet

bog violet

marsh violet

Wet-For

great-spurred violet

Con

\section{Oleaster Family}

Canadian buffalo-berry

C

For

\section{Evening Primrose}

\section{Family}

enchanter's-nightshade common fireweed

Pea

Mare's-tail Family

Wet 

ARALIACEAE

Aralia nudicaulis L.

UMBELLIFERAE

(APIACEAE)

Cicuta maculata L. var.

angustifolia Hook.

Heracleum lanatum Michx.

Sanicula marilandica $\mathrm{L}$.

\section{CORNACEAE}

Cornus canadensis L.

C. stolonifera Michx.

\section{PYROLACEAE}

Moneses uniflora (L.) A. Gray

Orthilia secunda (L.) House

Pyrola asarifolia Michx.

P. chlorantha Sw.

MONOTROPACEAE

Monotropa uniflora L.

\section{ERICACEAE}

Andromeda polifolia $\mathrm{L}$.

Arctostaphylos uva-ursi (L.)

Spreng.

Ledum groenlandicum Oeder

Oxycoccus microcarpus Turcz.

O. quadripetalus Gilib.

Vaccinium myrtilloides Michx.

V. vitis-idaea L. ssp. minus

(Lodd.) Hult.

\section{PRIMULACEAE}

Dodecatheon pulchellum (Raf.) Merr.

Lysimachia thyrsiflora L.

Primula incana M.E. Jones

\section{GENTIANACEAE}

Gentianella amarella (L.) Borner ssp. acuta (Michx.) Gillett

G. crinita (Froel.) G. Don ssp. macounii (Holm) Gillett

Halenia deflexa (Sm.) Griseb.

MENYANTHACEAE

Menyanthes trifoliata L.
Ginseng Family

wild sarsaparilla

2

C

For

\section{Carrot Family}

water-hemlock

cow parsnip

3-4

C

Wet

2-4

2-3

C

$\mathrm{Brl} /$

snake-root

C

Brl; Mix

\section{Dogwood Family}

bunchberry

red-osier dogwood

2-3

2-3

C

C

For

For; For/

\section{Wintergreen Family}

one-flowered

Con

wintergreen

one-sided wintergreen

common pink

$2-3$

U

C

Con; Mix

wintergreen

greenish-flowered

U

For; Pea

wintergreen

\section{Indian Pipe Family}

Indian pipe

Mix; Brl

\section{Heath Family}

bog rosemary

common bearberry

C

Pea

2
1

U

Pea

common Labrador tea

$2-3$

C

Con; Pea;

small bog cranberry

bog cranberry

common blueberry

bog cranberry

C

U

$\mathrm{O}$

C

Mix

Pea

Pea

Con

Pea

\section{Primrose Family}

saline shooting-star

Wet; Pea

tufted loosestrife

mealy primrose

U

C

Wet; Pea

Wet; Pea

\section{Gentian Family}

felwort

C

For; Gra

fringed gentian

3-4

C

spurred gentian

3-4

C

For

Buck-bean Family

buck-bean 

BORAGINACEAE

Mertensia paniculata (Ait.) G.

Don

\section{LABIATAE (LAMIACEAE)}

Agastache foeniculum (Pursh)

Ktze.

Galeopsis speciosa Mill. IX G. tetrahit L.

Mentha arvensis $\mathrm{L}$.

Scutellaria galericulata L.

Stachys palustris L. ssp. pilosa

(Nutt.) Epling

\section{SCROPHULARIACEAE}

Castilleja miniata Dougl. ex

Hook.

Limosella aquatica $\mathrm{L}$.

Pedicularis groenlandica Retz.

Veronica americana (Raf.) Schw.

\section{LENTIBULARIACEAE}

Pinguicula vulgaris L.

Utricularia intermedia Hayne

U. minor $\mathrm{L}$.

U. vulgaris L. ssp. Macrorhiza

(Le Conte) Clausen

\section{PLANTAGINACEAE}

Plantago major $\mathrm{L}$.

\section{RUBIACEAE}

Galium boreale L.

$$
\begin{aligned}
& \text { G. labradoricum Wieg. } \\
& \text { G. trifidum L. } \\
& \text { G. triflorum Michx. }
\end{aligned}
$$

\section{CAPRIFOLIACEAE}

Linnaea borealis L. ssp. americana (Forbes) Hult.

Lonicera dioica $\mathrm{L}$.

L. involucrata (Richards.) Banks Symphoricarpos albus (L.) Blake S. occidentalis Hook.

Viburnum edule (Michx.) Raf.

\section{ADOXACEAE}

Adoxa moschatellina $\mathrm{L}$.

\section{Borage Family}

tall lungwort

$2-3$

C

For; Shr

\section{Mint Family}

giant hyssop

3-4

$\mathrm{Brl}$; Shr

IX yellow hemp-nettle 3-4

3-4

$2-4$

wild mint

common skullcap

marsh hedge-nettle

3-4

$3-4$

\section{Figwort Family}

common red paintbrush

$2-4$

U

Gra; Shr; /

mudwort

4

elephant's-head

$\mathrm{O}$

Wet

American brooklime

C

C

Dis

Dis; For

Wet

Wet

Wet; Brl

\section{Bladderwort Family}

common butterwort

flat-leaved bladderwort

small bladderwort

common bladderwort
Pea; Wet

Wet

Pea

Wet

Wet

Pea

\section{Plantain Family}

I common plantain

\section{Madder Family}

northern bedstraw

Labrador bedstraw

small bedstraw

sweet-scented bedstraw
Dis

Gra; Shr; /;

Pea

Pea

Pea; Wet

Brl; Mix

\section{Honeysuckle Family}

twinflower

twining honeysuckle

bracted honeysuckle

snowberry

buckbrush

low bush-cranberry

\section{Moschatel Family}

moschatel
$2-3$

U

C

\section{2-3}

2

2-4

2-3
For

Brl; Mix; Pea/

For; Peal

Brl; Mix

Shr; $\mathrm{Brl} /$

Brl; Mix 

VALERIANACEAE

Valeriana dioica L. ssp. sylvatica (Rich.) F.G. Mey.

CAMPANULACEAE

Campanula rotundifolia $\mathrm{L}$.

LOBELIACEAE

Lobelia kalmii L.

\section{COMPOSITAE}

\section{(ASTERACEAE)}

Achillea millefolium L. ssp.

lanulosa (Nutt.) Piper

A. sibirica Ledeb.

Antennaria parvifolia Nutt.

Arnica chamissonis Less.

Aster borealis (T. \& G.) Prov.

A. brachyactis Blake

A. ciliolatus Lindl.

A. conspicuus Lindl.

A. hesperius A. Gray

A. laevis L.

A. modestus Lindl.

A. puniceus $\mathrm{L}$.

A. umbellatus Mill. var. pubens

Gray

Bidens cernua L.

Cirsium arvense (L.) Scop.

C. arvense forma albiflorum

(Rand \& Redf.) R. Hoffman

Crepis runcinata (James) T. \& G.

C. tectorum $\mathrm{L}$.

Erigeron acris L.

E. philadelphicus L.

Eupatorium maculatum L. R

Hieracium aurantiacum L. I

$H$. umbellatum $\mathrm{L}$.

Matricaria matricarioides (Less.)

Porter

M. perforata Merat

Petasites palmatus (Ait.) A. Gray

P. sagittatus (Pursh) A. Gray

$P$. vitifolius Greene

Senecio congestus (R. Br.) DC. .

$S$. eremophilus Richards.

S. pauperculus Michx.

Solidago canadensis L.

Sonchus uliginosus Bieb.

Tanacetum vulgare $\mathrm{L}$.

Taraxacum officinale Weber

\section{Valerian Family}

northern valerian

U

Wet/; Mix

\section{Bluebell Family}

harebell

3-4

U

Gra; Pea

\section{Lobelia Family}

Kalm's lobelia

$3-4$

C

Pea

\section{Composite/Daisy \\ Family}

common yarrow

3-4

Various

many-flowered yarrow 3-4

small-leaved everlasting $\quad 2$

? leafy arnica 3-4

rush aster $\quad 3-4$

rayless aster 3-4

Lindley's aster $\quad 3-4$

showy aster $\quad 3-4$

western willow aster $\quad 3-4$

smooth aster

$3-4$

large northern aster

purple-stemmed aster

flat-topped white aster

$\mathrm{R}$

nodding beggar-ticks

I Canada thistle

white Canada thistle

scapose hawksbeard

annual hawksbeard

northern daisy fleabane

Philadelphia fleabane

spotted Joe-Pye weed

orange hawkweed

narrow-leaved hawkweed

pineappleweed

C

Wet

Gra

For/

Wet; Pea

Dis

For

For; For/

Wet

Gra

I

Wet; Con/

$\mathrm{Brl}$; Pea

Wet

3-4

3-4

3-4

3-4

2-4

3

$2-3$

4

3

3-4

2-4

scentless chamomile $\quad 1-4$

palmate-leaved coltsfoot 1

arrow-leaved coltsfoot 1

vine-leaved coltsfoot 1

marsh ragwort

cut-leaved ragwort

balsam groundsel

Canada goldenrod

I smooth perennial sow

thistle

I common tansy

common dandelion
$1-4 \quad 0$

C

C

$1 \quad C$

2
Dis; $\mathrm{Brl}$

Dis

Wet

Dis

Gra; /

Wet; Pea

Wet

$\mathrm{Brl}$

For

Dis

Dis

Wet; For

Wet

Wet; For

Pea

For

For/

Gra; /

Dis

Dis

Various 



\section{APPENDIX 8 \\ Bryophytes, Lichens and Fungi of Wagner Natural Area}



Appendix 8. Bryophytes, Lichens and Fungi of Wagner Natural Area

(from Wagner Natural Area Plant Checklist, Natural History Information No. 88, December 1991; Alberta Culture and Multiculturalism, Provincial Museum of Alberta, Edmonton. Prepared and edited by Julia O. Hrapko. )

Contributors to this list: Dale H. Vitt, Christopher Miller, J. Derek Johnson, Alice Hendry.

\author{
Species Name
}

\section{Mosses}

Amblyodon dealbatus (Hedw.) B.S.G.

Amblystegium serpens (Hedw.) B.S.G.

Amblystegium varium (Hedw.) Lindb.

Aulacomnium palustre (Hedw.) Schwaegr.

Brachythecium campestre (C. Mull.) B.S.G.

Brachythecium mildeanum (Schimp.) Schimp. in

Milde

Brachythecium salebrosum (Web. \& Mohr) B.S.G.

Brachythecium starkei (Brid.) Schimp. in B.S.G.

Brachythecium turgidum (C.J. Hartm.) Kindb.

Bryoerythrophyllum recurvirostrum (Hedw.) Chen

Bryum pseudotriquetrum (Hedw.) Gaertn., Meyer \&

\section{Scherb.}

Calliergon giganteum (Schimp.) Kindb.

Campylium hispidulum (Brid.) Mitt.

Campylium radicale (P. Beauv.) Grout

Campylium stellatum (Hedw.) C. Jens.

Catoscopium nigritum (Hedw.) Brid.

Ceratodon purpureus (Hedw.) Brid.

Cinclidium stygium $\mathrm{Sw}$.

Climacium dendroides (Hedw.) Web. \& Mohr

Desmatodon cernuus (Hub.) B.S.G.

Dicranum elongatum Schleich.

Dicranum fragilifolium Lindb.

Dicranum polysetum Sw.

Dicranum undulatum Brid.

Distichium capillaceum (Hedw.) B.S.G.

Distichium inclinatum (Hedw.) B.S.G.

Drepanocladus aduncus (Hedw.) Warnst.

Drepanocladus crassicostatus Janssens

Limprichtia revolvens (Sw.) Loeske

Sanionia uncinata (Hedw.) Loeske

Hamatocaulis vernicosus (Mitt.) Hedenas

Eurhynchium pulchellum (Hedw.) Jenn.

Funaria hygrometrica Hedw.

Bryohaplocladium microphyllum (Hedw.) Wat. \& Iwats.

\section{Common Name}

pale-leaved thread moss

tufted moss

field verdant moss

clay grass moss

golden ragged moss

woodland verdant moss

thick ragged moss

red leaf moss

tall clustered thread moss

giant water moss

star moss

star moss

yellow star moss

golf club moss

purple horn-toothed moss

common northern lantern

moss

common tree moss

narrow-leafed chain-teeth

moss

long forked moss

cushion moss

wavy dicranum

wavy dicranum

hair-like opposite-leafed

moss

inclined-fruited opposite-

leafed moss

common hook moss

hook moss

red hook moss

sickle moss

hook moss

common beaked moss

cord moss

\section{Habitat Abundance}

$\begin{array}{ll}\text { Pea } & \mathrm{P} \\ \text { For } & \mathrm{C} \\ \text { For } & \mathrm{P}\end{array}$

Wet; Con C

For $P$

Pea; Wet U

For $\quad \mathrm{C}$

For U

Pea U

For; Dis $\mathrm{P}$

Pea; Wet C

Pea; Wet U

For C

For $\quad P$

Pea $\quad \mathrm{C}$

Pea $\quad \mathrm{O}$

Dis C

Pea $\mathrm{O}$

Wet U

Dis $\quad \mathrm{P}$

For? $\quad \mathrm{P}$

For $\quad U$

Con $\mathrm{O}$

Wet; Con C

Dis; For U

Dis; For $\quad \mathrm{O}$

Pea; Wet U

Pea P

Pea C

Wet; For C

Pea; Wet U

For C

Dis U

Brl; Mix O 

Helodium blandowii (Web. \& Mohr) Warnst.

Hylocomium splendens (Hedw.) B.S.G.

Hypnum lindbergii Mitt.

Hypnum pratense Koch ex Brid.

Leptobryum pyriforme (Hedw.) Wils.

Meesia triquetra (Richt. ) Angstr.

Meesia uliginosa Hedw.

Mnium spinulosum B.S.G.

Myurella julacea (Schwaegr.) B.S.G.

Onchophorus wahlenbergii Brid.

Orthotrichum obtusifolium Brid.

Orthotrichum speciosum Nees ex Sturm

Paludella squarrosa (Hedw.) Brid.

Plagiomnium cuspidatum (Hedw.) Kop.

Plagiomnium ellipticum (Brid.) Kop.

Platygyrium repens (Brid.) B.S.G.

Pleurozium schreberi (Brid.) Mitt.

Pohlia nutans (Hedw.) Lindb.

Polytrichum commune Hedw.

Polytrichum strictum Brid.

Pseudocalliergon turgescens (T. Jens.) Loeske

Ptilium crista-castrensis (Hedw.) De Not.

Pylaisiella polyantha (Hedw.) Grout

Rhizomnium gracile Kop.

Rhizomnium pseudopunctatum (Bruch \& Schimp.)

Kop.

Rhytidiadelphus triquetrus (Hedw.) Warnst.

Scorpidium scorpioides (Hedw.) Limpr.

Sphagnum angustifolium (Russ.) C. Jens.

Sphagnum fuscum (Schimp.) Klinggr.

Sphagnum capillifolium (Ehrh.) Hedw.

Sphagnum warnstorfii Russ.

Tetraphis pellucida Hedw.

Tetraplodon angustatus (Hedw.) B.S.G.

Thuidium recognitum (Hedw.) Lindb.

Tomenthypnum nitens (Hedw.) Loeske

Tortella tortuosa (Hedw.) Limpr.

\section{Liverworts}

Aneura pinguis (L.) Dum.

Blepharostoma trichophyllum (L.) Dum.

Conocephalum conicum (L.) Lindb.

Geocalyx graveolens (Schrad.) Nees

Jamesoniella autumnalis (DC.) Steph.

Lepidozia reptans (L.) Dum.

Marchantia polymorpha $\mathrm{L}$.

Mylia anomala (Hook.) S.F.Gray

Plagiochila asplenioides (L.) Dum.

Preissia quadrata (Scop.) Nees

Ptilidium ciliare (L.) Hampe

Ptilidium pulcherrimum (G. Web.) Hampe

$\begin{array}{lll}\text { Blandow's feather moss } & \text { Pea } & \text { U } \\ \text { stair-step moss } & \text { For } & \text { C } \\ \text { clay pigtail moss } & \text { Wet } & \text { U } \\ \text { meadow pigtail moss } & \text { Pea } & \text { U } \\ \text { long-necked bryum } & \text { Dis; For } & \text { C } \\ \text { three-angled thread moss } & \text { Pea } & \text { U } \\ \text { capillary thread moss } & \text { Wet } & \text { U } \\ \text { red-mouthed mnium } & \text { For } & \text { U } \\ \text { small mouse-tail moss } & \text { Con } & \text { O } \\ \text { mountain curved-back moss } & \text { For } & \text { C } \\ \text { blunt-leaved bristle moss } & \text { Brl; Mix } & \text { C } \\ \text { showy bristle moss } & \text { Brl; Mix } & \text { C } \\ \text { squarrose thread moss } & \text { Pea } & \text { O } \\ \text { woodsy mnium } & \text { Brl; Mix } & \text { C } \\ \text { marsh magnificent moss } & \text { Wet } & \text { C } \\ & \text { Brl; Mix } & \text { P } \\ \text { big red stem } & \text { For } & \text { C } \\ \text { copper wire moss } & \text { Dis; For } & \text { C } \\ \text { common hair-cap } & \text { Con } & \text { O } \\ \text { slender hair-cap } & \text { Pea; Con } & \text { C } \\ \text { yellow sausage moss } & \text { Pea } & \text { P P } \\ \text { knight's plume moss } & \text { For } & \text { C } \\ \text { stocking moss } & \text { Brl; Mix } & \text { C } \\ \text { small round moss } & \text { Wet } & \text { U } \\ \text { large round moss } & \text { Wet } & \text { U } \\ & & \\ \text { electrified cat's tail moss } & \text { Con } & \text { O } \\ \text { sausage moss } & \text { Pea } & \text { C } \\ \text { poor fen peat moss } & \text { Pea } & \text { U } \\ \text { rusty peat moss } & \text { Pea } & \text { C } \\ \text { acute-leaved peat moss } & \text { Con } & \text { O } \\ \text { Warnstorf's peat moss } & \text { Pea } & \text { C } \\ \text { common four-tooth moss } & \text { For } & \text { P } \\ \text { narrow-leaved splachnum } & \text { Con } & \text { P } \\ \text { hook-leaf fern moss } & \text { For } & \text { U } \\ \text { golden moss } & \text { Pea } & \text { C } \\ \text { twisted moss } & \text { Dis } & \text { P }\end{array}$

$\mathrm{U}$

U U (1) C C . ,

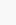

$\mathrm{P}$



Lichens of Wagner Natural Area (Contributors to this list: Janet Marsh \& J. Derek Johnson)

Arthonia patellulata $\mathrm{Nyl}$.

aspen comma

Biatora vernalis (L.) Fr.

Bryoria fuscescens (Gyelnik) Brodo \& D. Hawksw.

Buellia triphragmioides Anzi

Caloplaca cerina (Ehrh.) Th. Fr.

Caloplaca holocarpa (Hoffm.) Wade

Caloplaca ulmorum (Fink) Fink

Candelaria concolor (Dicks.) B. Stein var. effusa

(Tuck.) Burnh.

Candelariella vitellina (Ehrh.) Mull. Arg.

Cladina arbuscula (Wallr.) Hale \& W. Culb

Cladina mitis (Sandst.) Hale \& W. Culb.

Cladina rangiferina (L.) Harm.

Cladonia bacillaris (Ach.) Nyl.

Cladonia botrytes (Hag.) Willd.

Cladonia cenotea (Ach.) Schaer.

Cladonia chlorophaea (Floerke ex Somm.) Spreng.

Cladonia borealis S. Stenroos

Cladonia coniocraea (Floerke) Spreng.

Cladonia cornuta (L.) Hoffm.

Cladonia crispata (Ach.) Flot.

Cladonia cristatella Tuck.

Cladonia deformis (L.) Hoffm.

Cladonia fimbriata (L.) Fr.

Cladonia furcata (Huds.) Schrad.

Cladonia gracilis ssp. turbinata (Ach.) Ahti

Cladonia multiformis Merr.

Cladonia pleurota (Florke) Schaerer

Cladonia pyxidata (L.) Hoffm.

Cladonia scabriuscula (Del. ex Duby) Nyl.

Cladonia subulata (L.) Wigg.

Cladonia uncialis (L.) Wigg.

Evernia mesomorpha $\mathrm{Nyl}$.

Flavopunctelia flaventior (Stirton) Hale

Hypogymnia physodes (L.) W. Wats.

Imshaugia aleurites (Ach.) S.F. Meyer

Lecania dubitans (Nyl.) A.L. Sm.

Lecanora caesiorubella Ach. ssp. saximontana

Imsh. \& Brodo

Lecanora circumborealis Brodo \& Vitik.

Lecanora meridionalis Magnusson

? Lecanora pseudochlarotera Brodo

Lecanora pulicaris (Pers.) Ach.

Lecanora symmicta (Ach.) Ach.

Lecidella euphorea (Florke) Hertel

Melanelia exasperatula (Nyl.) Essl.

Melanelia septentrionalis (Lynge) Essl.

Melanelia subaurifera (Nyl.) Essl.

Ochrolechia arborea (Kreyer) Almb.

Punctelia subrudecta (Nyl.) Krog

Parmelia sulcata Tayl.

speckled horsehair

button lichen

crusted orange lichen

orange lichen

orange lichen

lemon lichen

egg lichen

greater green reindeer lichen

lesser green reindeer lichen

grey reindeer lichen

lipstick powderhorn

stump soldiers

miner's funnel

mealy pixie-cup

boreal pixie-cup

lesser powderhorn

common bighorn

greater organpipe

British soldiers

lesser sulphur-cup

powdered trumpet

many-forked cladonia

bronzed pixie-cup

slotted cladonia

mind-altering pixie-cup

pebbled pixie-cup

many-winged cladonia

antlered powderhorn

thorn cladonia

boreal oakmoss

green speckleback

monk's-hood

salted starburst

lustrous brown

northern brown

abraded brown

forest speckleback

powdered shield

$\begin{array}{ll}\text { Brl; Mix } & \text { U } \\ \text { For } & \text { C } \\ \text { Con } & \text { O } \\ \text { For } & \text { P } \\ \text { Brl; Mix } & \text { C } \\ \text { Brl; Mix } & \text { C } \\ \text { Brl; Mix } & \text { P } \\ \text { Con } & \text { C }\end{array}$

Con $\mathrm{P}$

Con $\mathrm{P}$

Con C

Con U

Con U

Con O

Con U

Con C

Con $\mathrm{O}$

Con C

Con C

Con U

Con $P$

Con U

Con U

Con $\mathrm{O}$

Con C

Con U

Con $P$

Con U

Con O

Con $\mathrm{O}$

Con $\mathrm{P}$

Mix; Con C

For C

For $\quad \mathrm{C}$

Con $\mathrm{O}$

For $P$

For $\quad P$

For C

For $\quad P$

For $\quad P$

For $\quad P$

For $\quad P$

For U

Con U

Shr, Con O

Con C

For U

For U

For $\mathrm{C}$ 

Parmeliopsis ambigua (Wulf.) Nyl.

Parmeliopsis hyperopta (Ach.) Arn.

Peltigera aphthosa (L.) Willd.

Peltigera canina (L.) Willd.

Peltigera elisabethae Gyeln.

Phaeophyscia orbicularis (Neck.) Moberg

Physcia adscendens (Th. Fr.) Oliv.

Physcia aipolia (Ehrh.) Hampe

Phaeophyscia hispidula (Ach.) Essl.

Physcia stellaris (L.) Nyl.

Physconia detersa (Nyl.) Poelt

Ramalina farinacea (L.) Ach.

Ramalina americana Hale

Ramalina roesleri (Hochst. ex Schaer.) Hue

Rinodina dakotensis Magn.

Rinodina exigua (Ach.) S. Gray

Trapeliopsis flexuosa (Fr.) Coppins \& P. James

Trapeliopsis granulosa (Hoffm.) Lumbsch

Tuckermannopsis americana (Sprengel) Hale

Usnea cavernosa Tuck.

Usnea hirta (L.) Wigg.

Usnea lapponica Vainio

Vulpicida pinastri (Scop.) J.-E. Mattsson \& M.J. Lai

Xanthoria fallax (Hepp.) Arn.

Xanthoria polycarpa (Ehrh.) Oliv.

Xylographa parallela (Ach.:Fr.) Behlen \& Desberg

$\begin{array}{lll}\text { green starburst } & \text { Con } & \text { C } \\ \text { grey starburst } & \text { Con } & \text { C } \\ \text { freckle pelt } & \text { Con } & \text { C } \\ \text { dog pelt } & \text { Con } & \text { C } \\ \text { concentric pelt } & \text { Con } & \text { O } \\ \text { granulated shadow } & \text { Brl; Mix } & \text { U } \\ \text { hooded rosette } & \text { For } & \text { C } \\ \text { grey-eyed rosette } & \text { For } & \text { C } \\ \text { whiskered shadow } & \text { For } & \text { P } \\ \text { black-eyed rosette } & \text { For } & \text { U } \\ \text { bottlebrush frost } & \text { Brl; Mix } & \text { O } \\ \text { the dotted line } & \text { Con } & \text { U } \\ \text { bush } & \text { Con } & \text { U } \\ \text { frayed bush } & \text { Con } & \text { P } \\ & \text { For } & \text { P } \\ & \text { For } & \text { P } \\ & \text { For } & \text { P } \\ & \text { For } & \text { P } \\ \text { fringed ruffle } & \text { Con } & \text { U } \\ \text { pitted beard } & \text { Con } & \text { O } \\ \text { bristly beard } & \text { Con } & \text { U } \\ \text { powdered beard } & \text { Con } & \text { C } \\ \text { powdered sunshine } & \text { Con } & \text { C } \\ \text { powdered orange } & \text { Brl; Mix } & \text { C } \\ \text { pincushion orange } & \text { Brl; Mix } & \text { C } \\ \text { script lichen } & \text { Brl; Mix } & \text { P }\end{array}$

Fungi of Wagner Natural Area (based on collections by Andrew Hendry, and identifications by Randy Currah and Sean Abbott, University of Alberta Devonian Botanic Garden.)

Agaricus micromegathus Peck

Agaricus silvicola (Vitt.) Sacc.

*Armillaria sp.

Auriscalpium vulgare S.F.Gray

Bjerkandera adusta (Fr.) Karst

Calocera cornea (Batsch: Fr.) Fr.

Cantharellus tubaeformis Fr.

Cerrena unicolor (Fr.) Murr.

Chlorociboria aeruginascens (Nyl.) Kan. ex Ram.,

Korf \& Batra

Chroogomphus rutilus (Fr.) O.K. Miller

Clavariadelphus ligula (Fr.) Donk

Collybia dryophila (Bull.: Fr.) Kummer

Coltricia perennis (L. : Fr.) Murr.

Coprinus atramentarius (Bull. : Fr.) Murr.

Cortinarius amoenolens Henry ex Horton

Cortinarius collinitus Fr.

Cortinarius pholideus (Fr.) Fr.

Crepidotus applanatus (Pers.) Kummer

Crepidotus variabilis (Pers.: Fr.) Kummer

Cystoderma amiantinum (Scop. :Fr.) Fayod woodland Agaricus

earspoon fungus

smoky polypore

staghorn jelly fungus

trumpet chanterelle

grey polypore

green cups

pegtop

pestle fungus

June mushroom

fairy stool

smooth inky cap

flat Crepidotus

unspotted Cystoderma 

Cystoderma cinnabarinum (Secr.) Fayod

Cystoderma fallax Smith and Singer

Dacryopinax sp.

Daedaleopsis confragosa (Bolt. : Fr.) Schruet.

Dentinum repandum (L. : Fr.) S.F. Gray

Dermocybe cinnamomea (L. Fr.) Ricken.

Entoloma lividum Fr.

Favolus alveolaris (DC.: Fr.) Wuel.

Fomitopsis pinicola (Fr.) Kasts.

Fuscoboletinus aeruginascens (Secr.) Pomerleau and Smith

Fuscoboletinus spectabilis (Peck) Pomerleau and Smith

Galerina mycenopsis (Fr. : Fr.) Kuehn.

Geastrum saccatum $\mathrm{Fr}$.

Geastrum triplex Jungh.

Hebeloma crustuliniforme (Bull. ex Saint-Amans)

Quel.

Hirschioporus pargamenus

Hypomyces hyalinus (Schw.: Fr.) Tul.

Hypomyces luteovirens (Fr.) Tul.

Inocybe fastigiata (Schaeff. : Fr.) Quel.

Inocybe leucoblema Kuehn.

Irpex lactea (Fr. : Fr.) Fr.

Laccaria laccata (Fr. ) Berk, \& Br.

Lactarius deliciosus (L. :Fr.) Gray

Lactarius scrobiculatus (Scop. : Fr.) Fr.

Lactarius torminosus (Schaeff. : Fr.) S.F. Gray

Leccinum scabrum (Bull.: Fr.) S.F. Gray

Lentinellus cochleatus (Fr.) Karst.

Lenzites betulina (L. : Fr.) Fr.

Leocarpus fragilis (Dicks.) Rost.

Lepiota clypeolaria (Bull. ex Fr.) Kummer

Lepiota cristata (A. \& S. ex Fr.) Kummer

Marasmius androsaceus (L.) Fr.

Mycena pura (Pers. : Fr.) Kummer

Otidea leporina (Fr.) Fuckel

Panus rudis Fr.

Peniophora rufa (Fr.) Boid.

Peziza repanda Pers.

Phellinus punctatus (Fr.) Pilat

Pleurotus porrigens (Pers. ex Fr.) Singer

Polyporus elegans Bull. : Fr.

Rhytisma andromedae $\mathrm{Fr}$.

Rhytisma salicinum Fr.

Schizophyllum commune Fr.

Scutellinia scutellata (L. : Fr.) Lambotte vermilion Cystoderma

conifer Cystoderma

spreading hedgehog

mushroom

red belt fungus

greyish larch bolete

admirable bolete

rounded earthstar

collared earthstar

poison pie

yellow-green Hypomyces

deadly Inocybe

fibrehead

orange Laccaria

delicious milkcap

pitted milkcap

woolly milkcap

birch bolete

white-gilled polypore

shaggy-stalked parasol

pinwheel

pink Mycena

donkey's ears

brown cup

elegant polypore

split-gill

red eyelash cup 

Spathularia flavida Pers. : Fr.

Suillus grevillei (Kl.) Singer

Suillus tomentosus (Kauf.) Snell, Singer \& Dick

Tricholoma vaccinum (Pers. ex Fr.) Kummer

Trogia crispa Fr. yellow earth tongue

tamarack Jack

woolly pine bolete

scaly Tricholoma

Formerly Armillaria mellea was thought to occur in Wagner; now this species is not believed to occur in Alberta. The two species of Armillaria now reported for Alberta are A. ostoyae (Romagn.) Herink and A. sinapina Berube \& Dessureault. It is not yet know which one occurs, or whether both occur, in Wagner.

Please note: Key for habitat and abundance abbreviations is the same as for vascular plants (see Appendix 7) 



\section{APPENDIX 9}

\section{Alberta Natural Heritage \\ Information Centre \\ Definitions}



Appendix 9: Alberta Natural Heritage Information Centre Definitions (from ANHIC 2000).

Last Updated January 27, 2000

Explanation of ranks: $\mathrm{G}=\mathrm{Global} ; \mathrm{S}=\mathrm{Alberta}$

\begin{tabular}{|l|l|l|}
\hline Rank & Frequency/Distribution & Concerns/Comments \\
\hline S1/G1 & $\begin{array}{l}\text { 5 or fewer occurrences or only a few remaining } \\
\text { individuals }\end{array}$ & $\begin{array}{l}\text { May be especially vulnerable to extirpation } \\
\text { because of some factor of its biology }\end{array}$ \\
\hline $\mathbf{S 2 / G 2}$ & $\begin{array}{l}\text { 6-20 or fewer occurrences or with many } \\
\text { individuals in fewer locations }\end{array}$ & $\begin{array}{l}\text { May be especially vulnerable to extirpation } \\
\text { because of some factor of its biology }\end{array}$ \\
\hline $\mathbf{S 3 / G 3}$ & $\begin{array}{l}\text { 21-100 occurrences, may be rare and local } \\
\text { throughout it's range, or in a restricted range } \\
\text { (may be abundant in some locations) }\end{array}$ & $\begin{array}{l}\text { May be susceptible to extirpation because of } \\
\text { large scale disturbances }\end{array}$ \\
\hline $\mathbf{S 4 / G 4}$ & Typically $>100$ occurrences & Apparently secure \\
\hline $\mathbf{S 5 / G 5}$ & Typically $>100$ occurrences & Demonstrably secure \\
\hline
\end{tabular}

\section{A NUMBER OF OTHER CODES ARE USED TO CLARIFY THE STATUS OF AN ELEMENT}

- A-Accidental or casual in the province, includes species (usually birds or butterflies) recorded very infrequently, commonly far outside their usual range.

- B - A rank modifier indicating breeding status for a migratory species.

- C - Element is presently existing in the province only in captivity or cultivation.

- $\quad \mathbf{E}$ - Exotic species established in province, may be native to nearby regions.

- H - Historically known, may be relocated in future.

- HYB - Hybrid taxon that is recurrent in the landscape.

- $\quad \mathbf{N}$-A rank modifier indicating non-breeding status for a migratory species.

- $\quad \mathbf{P}$ - Potentially exists in province but no occurrences reported.

- $\mathbf{Q}$ - Taxonomic problems involved, more information needed.

- $\quad \mathbf{R}$ - Reported for Alberta but lacking documentation which would provide a basis for either accepting or rejecting the report (e.g. misidentified specimen).

- $\quad$ RD - Report dubious

- $\quad$ RF - Falsely reported for Alberta but this error persists in the literature.

- SYN - Synonym; element reported as occurring in Alberta, but province does not recognize the taxon.

- T - Rank for subspecific taxon (subspecies or variety).

- U - Status uncertain often because of low search effort or cryptic nature of the element, possibly in peril, unrankable, more information needed.

- $\mathbf{X}$ - Believed to be extinct or extirpated, historical records only.

- $\quad$ Z - Ranking not applicable (e.g. migrants only).

- _? - Rank questionable

- ? - Not yet ranked in Alberta or rank tentatively assigned. 


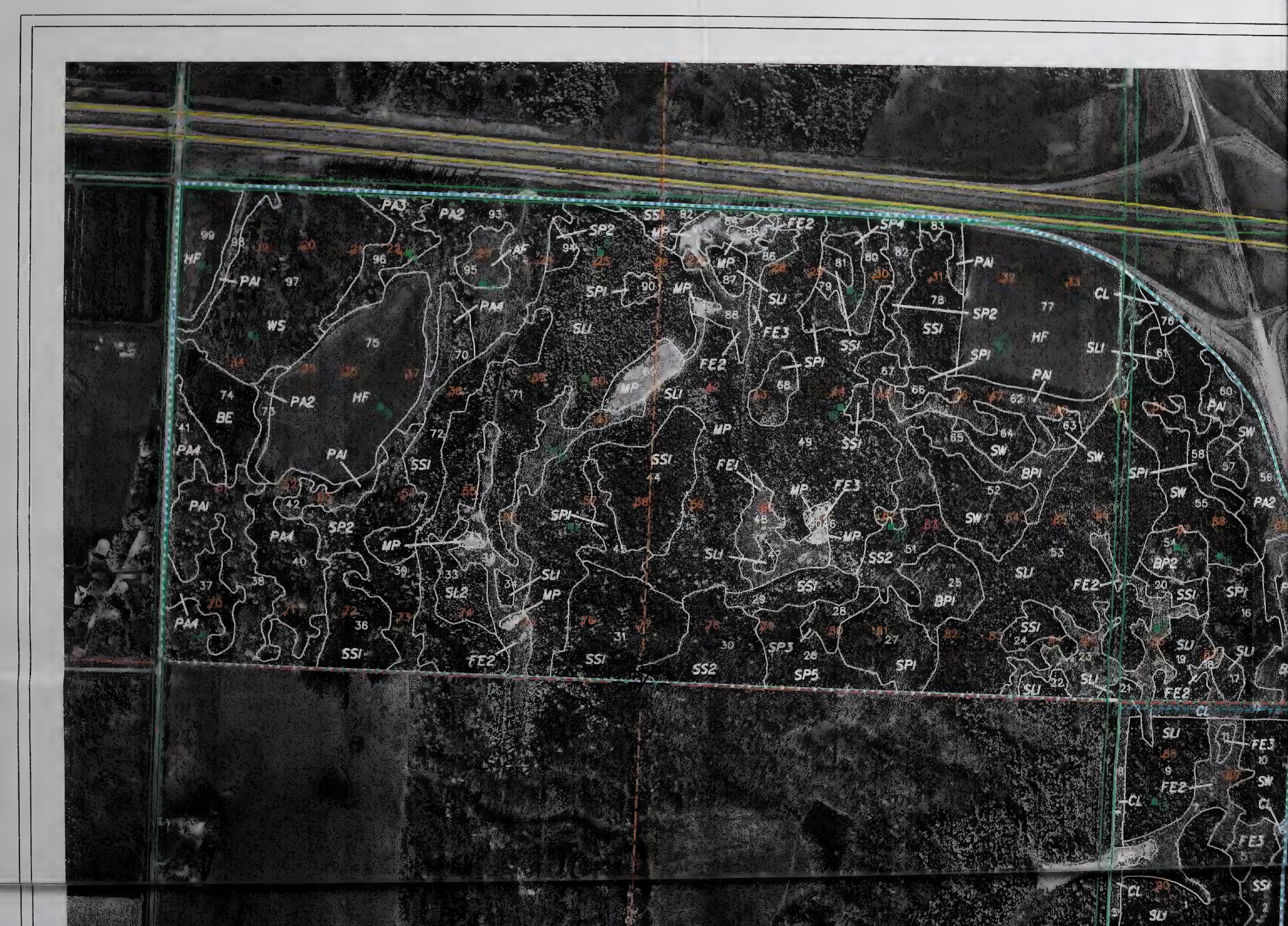




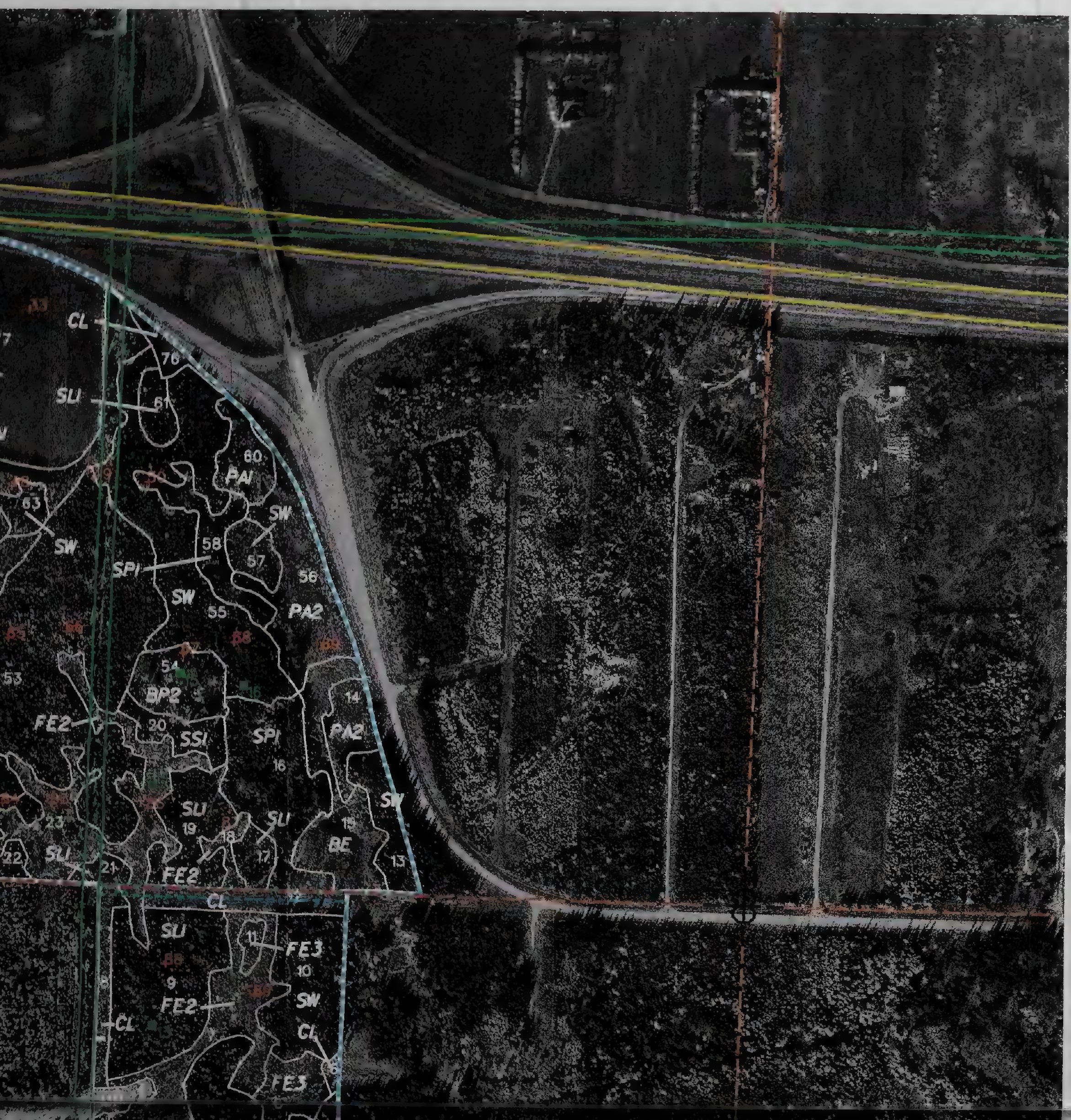

\section{Vegetatic
Wagr}

\begin{tabular}{|c|c|}
\hline Mop Unit & Description \\
\hline & Alasko Birch - Balsam Poplar Community Subtypes \\
\hline BP1 & $\mathrm{Bw}-\mathrm{Pb} /$ dewberry/sedge \\
\hline \multirow[t]{2}{*}{ BP2 } & Bw-Pb/bunchberry \\
\hline & Fen Community Subtypes \\
\hline FE1 & bulrush-sedge/moss fen \\
\hline FE2 & dwarf birch/sedge/moss fen \\
\hline \multirow[t]{2}{*}{ FE3 } & Lt-Sb/dwarf birch-willow/sedge/moss fen \\
\hline & Balsam Poplar - Aspen Community Subtypes \\
\hline PA1 & Pb-Aw/dewberry \\
\hline PA2 & $\mathrm{Pb}-\mathrm{Aw} /$ willow/blue joint \\
\hline PA3 & Pb-Aw/biue joint-sedge \\
\hline \multirow[t]{2}{*}{ PA4 } & $\mathrm{Pb}$-Aw/dogwood \\
\hline & Black Spruce - Tamarack Community Subtypes \\
\hline SLi & Sb-Lt/Labrador tea/feather moss \\
\hline \multirow[t]{2}{*}{ SL2 } & Sb-Lt/Labrador tea/feather moss-peat moss \\
\hline & White Spruce - Balsam Poplar Community Subtypes \\
\hline SP1 & $\mathrm{Sw}-\mathrm{Pb} /$ dewberpy \\
\hline SP2 & $\mathrm{Sw}-\mathrm{Pb} /$ willow-dogwood \\
\hline SP3 & $\mathrm{Sw}-\mathrm{Pb} /$ bunchberry/horsetail \\
\hline SP4 & $\mathrm{Sw}-\mathrm{Pb} / \mathrm{clover}$ \\
\hline \multirow[t]{2}{*}{ SP5 } & $\mathrm{Sw}$-Pb/moss \\
\hline & White Spruce - Black Spruce Community Subtypes \\
\hline SS1 & Sw-Sb/dewberry/sedge/feather moss \\
\hline \multirow[t]{2}{*}{ SS2 } & Sw-Sb/horsetali \\
\hline & White Spruce Community Type \\
\hline \multirow[t]{2}{*}{ SW } & Sw/bunchberry/feather moss \\
\hline & Willow Community Type \\
\hline \multirow[t]{2}{*}{ ws } & willow/sedge-bluejoint \\
\hline & Miscellaneous Cover Types \\
\hline AF & Abondoned field \\
\hline
\end{tabular}




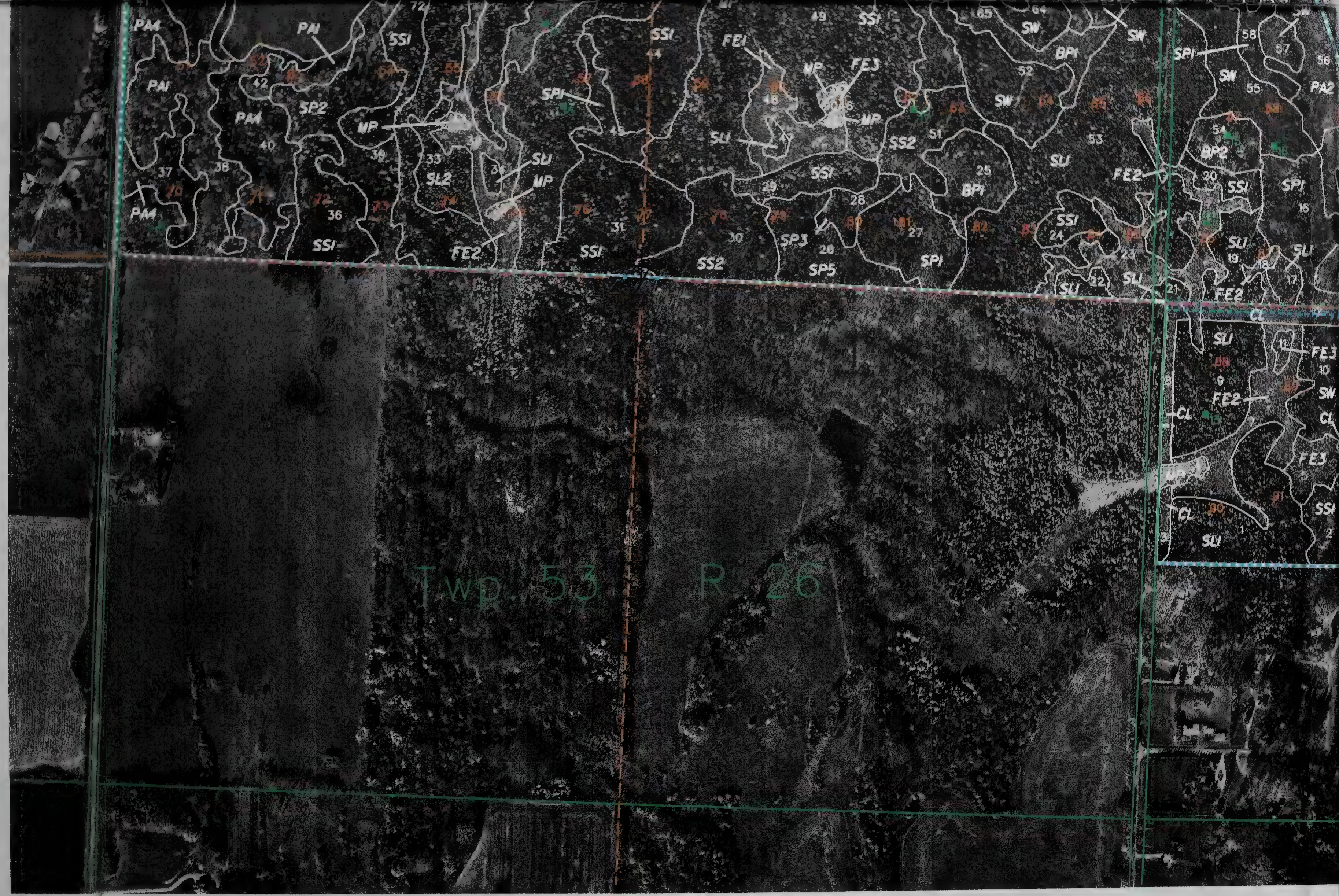




\begin{tabular}{|c|c|c|c|c|c|}
\hline & & & & poritiosonopric & \\
\hline PA3 & $\begin{array}{l}\mathrm{Pb}-\mathrm{Aw} / \text { blue joint-sedge } \\
\mathrm{Pb} \text {-Aw/dogwood }\end{array}$ & $\begin{array}{l}\text { Mature seral } \\
\text { Mature seral }\end{array}$ & $\begin{array}{c}\text { subhygric-subhydric } \\
\text { subhygric-hygric }\end{array}$ & $\begin{array}{c}\text { permesotrophic } \\
\text { permesotrophic-mesotrophic }\end{array}$ & $\begin{array}{c}\text { GSP6 } \\
\text { GSP1; GSP4; GSP8 }\end{array}$ \\
\hline & Black Spruce - Tamarack Community Subtypes & & & & \\
\hline SL1 & $\begin{array}{l}\text { Sb-Lt/Labrador tea/feather moss } \\
\text { Sb-Lt/Labrador tea/feather moss-peat moss }\end{array}$ & $\begin{array}{l}\text { Mature edaphic climax } \\
\text { Mature edaphic climax }\end{array}$ & $\begin{array}{l}\text { hygric-subhydric } \\
\text { hygric }\end{array}$ & $\begin{array}{l}\text { permesotrophic } \\
\text { permesotrophic }\end{array}$ & $\begin{array}{l}\text { GSP7: GSP3: GSP4; WNR1: WNR2 } \\
\text { GSP4 }\end{array}$ \\
\hline & White Spruce - Bolsom Poplor Community Subtypes & & & & \\
\hline SP1 & Sw-Pb/dewberry & Mature seral & subhygric & permesotrophic & RVN1; GSP3; WNR2; GSP2; GSP4 \\
\hline SP2 & Sw-Pb/willow-dogwood & Mature seral & hygric-subhydric & permesotrophic & GSP4; GSP3 \\
\hline SP3 & $\mathrm{Sw}-\mathrm{Pb} / \mathrm{b} u n c h b e r r y / h o r s e t a i l$ & Mature seral & hygric & permesotrophic & RVN1 \\
\hline SP4 & $\mathrm{Sw}-\mathrm{Pb} /$ clover & Young serd & subhygric & permesotrophic & RVN1 \\
\hline SP5 & $\mathrm{Sw}-\mathrm{Pb} /$ moss & Mature seral & subhygric & permesotrophic & RVN1 \\
\hline & White Spruce - Block Spruce Community Subtypes & & & & \\
\hline SS1 & $\mathrm{Sw}-\mathrm{Sb} /$ dewberry/sedge/feather moss & Mature edophic climax & subhygric-hygric & permesotrophic & GSP3; GSP4; WNR2; CVL2; RVN1 \\
\hline ss2 & Sw-Sb/horsetail & Mature edaphic climax & hygric-subhydric & mesotrophic-permesotrophic & GSP3 \\
\hline sW & $\begin{array}{l}\text { White Spruce community Type } \\
\text { Sw/bunchberry/feather moss }\end{array}$ & $\begin{array}{l}\text { Moture edaphic climax } \\
\text { (Young edaphic climax) }\end{array}$ & mesic-subhygric & mesotrophic-permesotrophic & WNR2; CVL2: GSP3; GSP1 \\
\hline & Willow Community Type & & & & \\
\hline ws & willow/sedge-bluejoint & Young serali & hydric-hygric & permesotrophic & GSP8 \\
\hline & Miscellaneous Cover Types & & & & \\
\hline AF & Abandoned field & Old field & subxeric-submesic & mesotrophic-permesotrophic & BRK1 \\
\hline$B E$ & Beaver pond and associated flooding area & Pioneer seral: & - & & GSP1; ZWA2 \\
\hline $\mathrm{CL}$ & Clearing & Pioneer seral & - & - & GSP7; GSP1; WNR1; WNR2 \\
\hline HF & Hay field & Cultivated pasture & submesic-mesic & mesotrophic & CVL1; CVL2; CVL3 \\
\hline MP & Marl pond & Non vegetoted & - & - & ZWA 1 \\
\hline
\end{tabular}

\section{Map Features}

\section{Vegetation Polygon Line}

Study Area Boundary

....- Wagner Natural Area Boundary

72 Reconnaissance Sample Site

\section{Alberta Township System Section Lines}

-9 Detailed Sample Site

- - Alberta Township System Quarter Section Lines LCommunity subtype

Highway

Meters $\stackrel{0}{L}$ 100 $\stackrel{200}{1}_{\text {Map scale } 1: 5,000}^{300}$ $\stackrel{400}{1}$ $\stackrel{500}{5}$ 


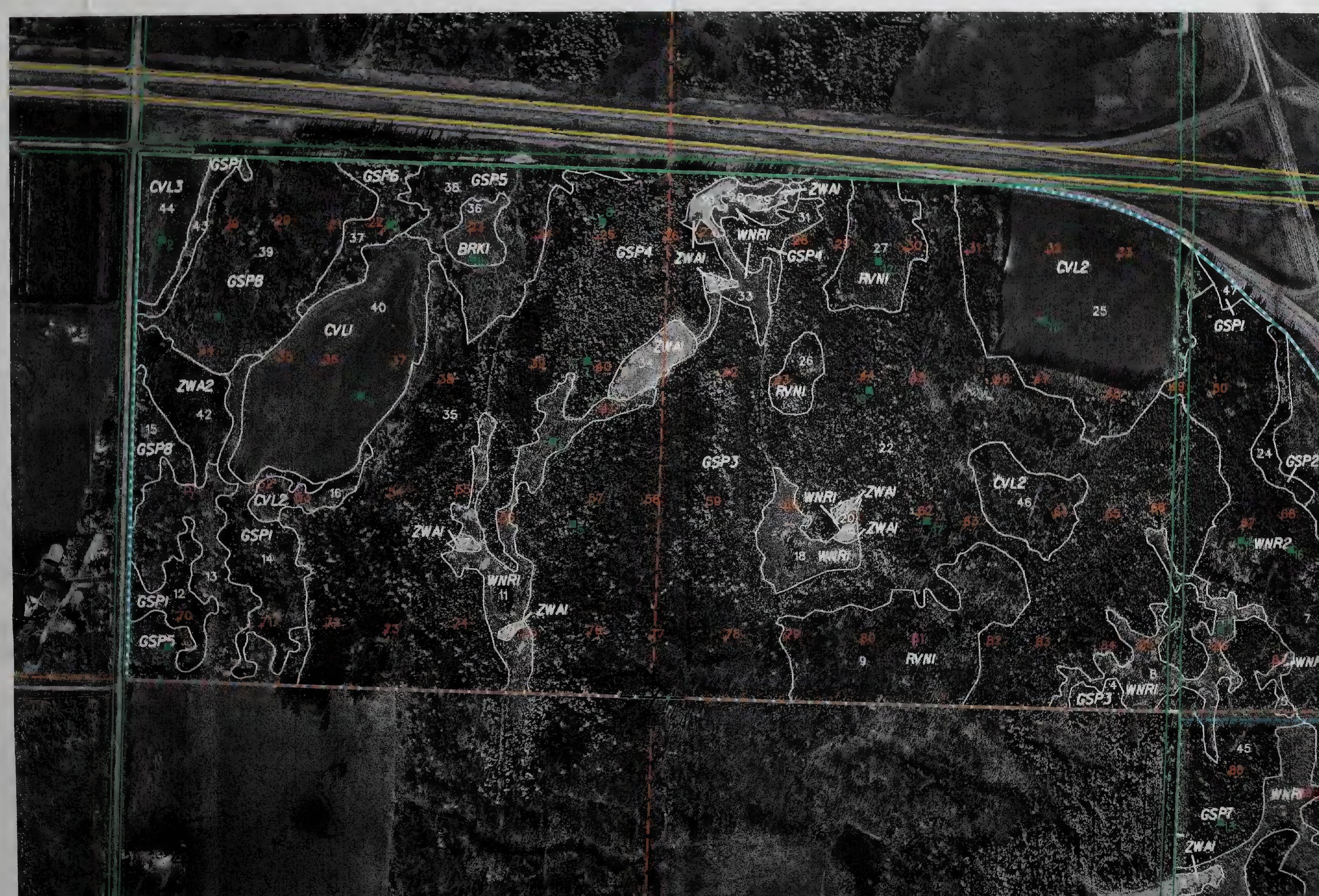




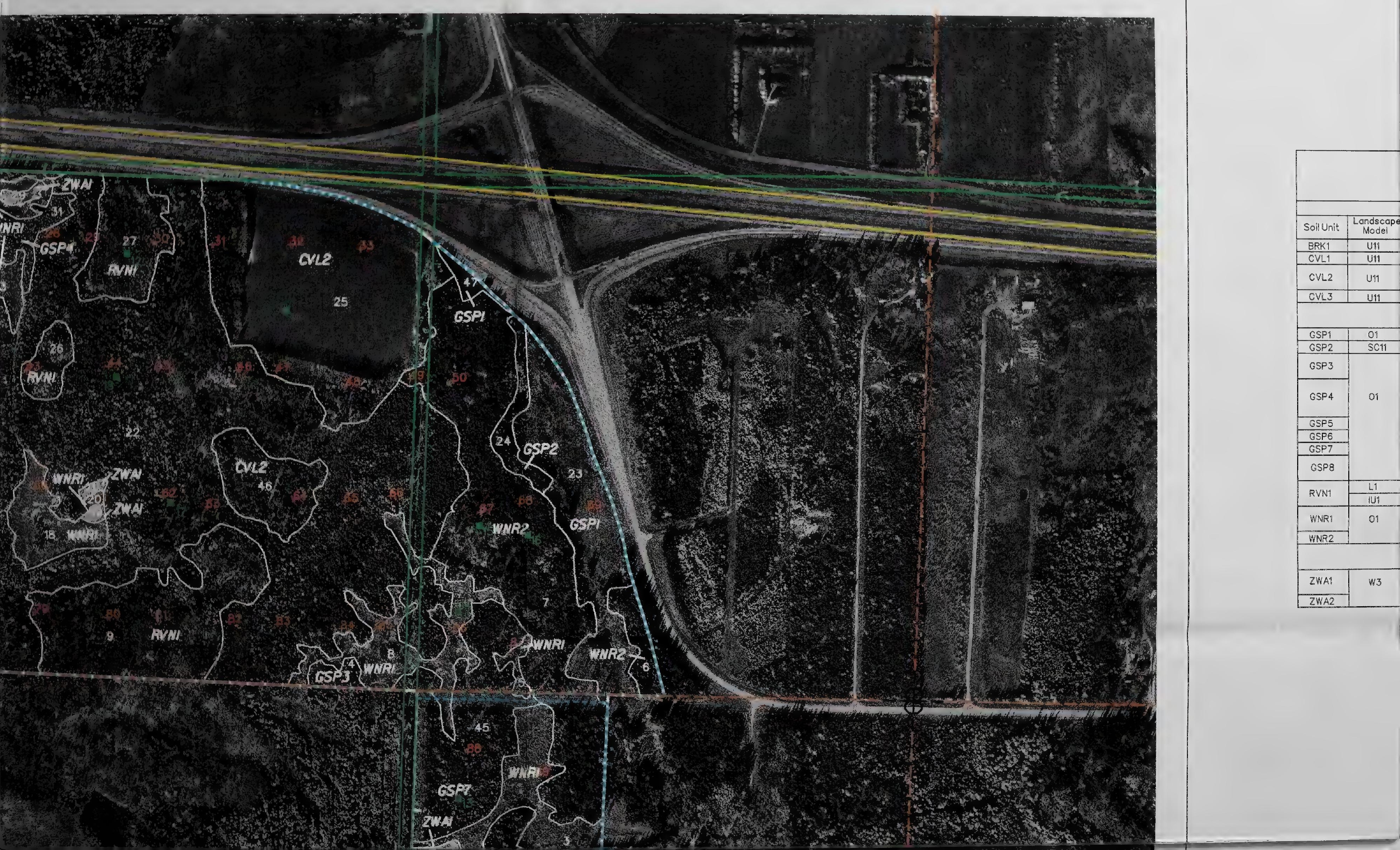




\begin{tabular}{|c|c|c|c|c|c|}
\hline \multicolumn{6}{|c|}{$\begin{array}{c}\text { Soils of } \\
\text { Wagner Notural Area }\end{array}$} \\
\hline \multicolumn{6}{|c|}{ Moderately Well Drained Soils } \\
\hline Soil Unit & $\begin{array}{l}\text { Landscape } \\
\text { Model }\end{array}$ & Parent Material & Dominant $(>70 \%)$ or Co-dominant $(30-60 \%)$ Soils & Significant $(\langle 15 \%)$ Solls & $\begin{array}{l}\text { Soil Polygon } \\
\text { Numbers }\end{array}$ \\
\hline BRK1 & U11 & Glaciofluvial & Dark Gray Luvisols & & 36 \\
\hline CVL1 & U11 & \multirow{3}{*}{ Glociofluvial } & Dark Gray Luvisols (CVL) & Dark Gray Luvisols (BRK) & 40 \\
\hline CVL2 & U11 & & carbonated Gleyed Dark Gray Luvisols & carbonated peaty Orthic Humic Gleysols & $16,25,46$ \\
\hline CVL3 & U11 & & Calcareous Dark Gray Chernozems & & 44 \\
\hline \multicolumn{6}{|c|}{ Poorly and Very Poorly Drained Solls } \\
\hline GSP1 & 01 & \multirow{7}{*}{ Fen peat } & carbonated Terric Mesisols & & $12,14,23,43$ \\
\hline GSP2 & SC11 & & carbonated Terric Mesisols & & 24 \\
\hline GSP3 & \multirow{6}{*}{01} & & $\begin{array}{l}\text { carbonated Terric Mesisols and carbonated } \\
\text { Terric Humisols }\end{array}$ & carbonated Typic Mesisols & 4,22 \\
\hline GSP4 & & & carbonated Terric Mesic Humisols & $\begin{array}{c}\text { carbonated Typic Mesisols, carbonated } \\
\text { Fibric Mesisols and carbonated Humic } \\
\text { Mesisols }\end{array}$ & 31,35 \\
\hline GSP5 & & & carbonated Terric Humisols & carbonated Typic Mesisols & 13,38 \\
\hline GSP6 & & & corbonated Terric Humic Mesisols & carbonated Typic Mesisols & 37 \\
\hline GSP7 & & & Typic Humisols & Typic Mesisols & 1,45 \\
\hline GSP8 & & Forest peat & carbonated Typic Mesisols & $\begin{array}{l}\text { Limnic Mesisols and carbonated } \\
\text { Mesic Humisols }\end{array}$ & 15,39 \\
\hline RVN1 & $\frac{\mathrm{LI}}{\mathrm{IU1}}$ & Glaciolacustrine & carbonated peaty Orthic Humic Gleysols & carbonated Terric Mesisols & $\frac{26.27}{9}$ \\
\hline WNR1 & \multirow[t]{2}{*}{01} & \multirow[t]{2}{*}{ Marl } & carbonated Rego Gieysols & Water & $\begin{array}{l}3,5,8,11,18 \\
20,28,33 \\
\end{array}$ \\
\hline WNR2 & & & carbonated Rego Gleysols & carbonated Terric Mesisols & 6,7 \\
\hline \multicolumn{6}{|c|}{ Standing Water } \\
\hline ZWA1 & \multirow[t]{2}{*}{ w3 } & \multirow[t]{2}{*}{ Water } & Standing water & & $\begin{array}{l}2,10,17,19,21, \\
29,30,32,34 \\
\end{array}$ \\
\hline ZWAZ & & & Standing water & carbonated Terric Mesisols & 42 \\
\hline
\end{tabular}

\section{Map Features}

Soils Polygon Line

Study Area Boundary

... - Wagner Natural Area Boundary

Alberta Township System Section Lines

- Alberta Township System Quorter Section LInes

Highway 


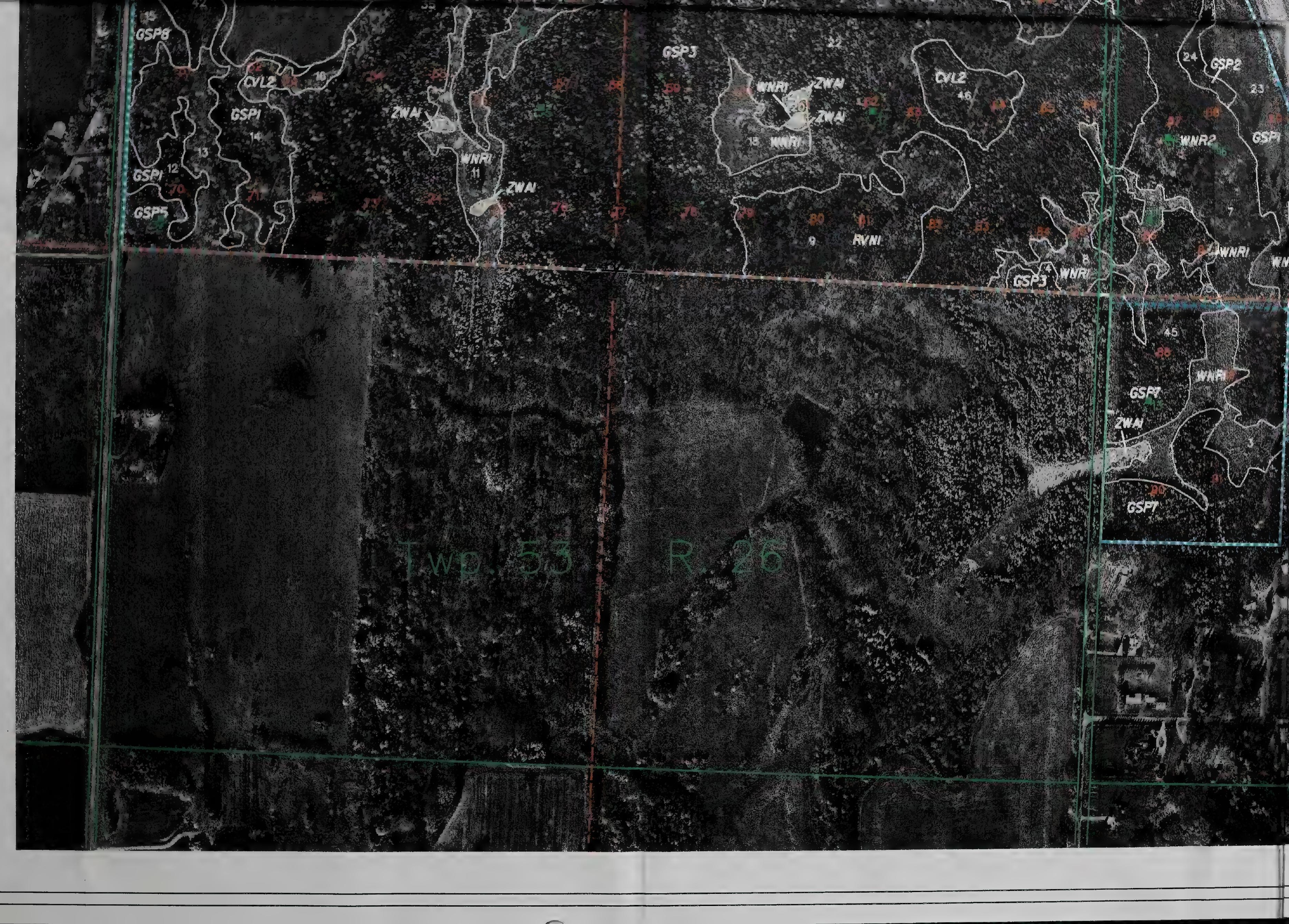




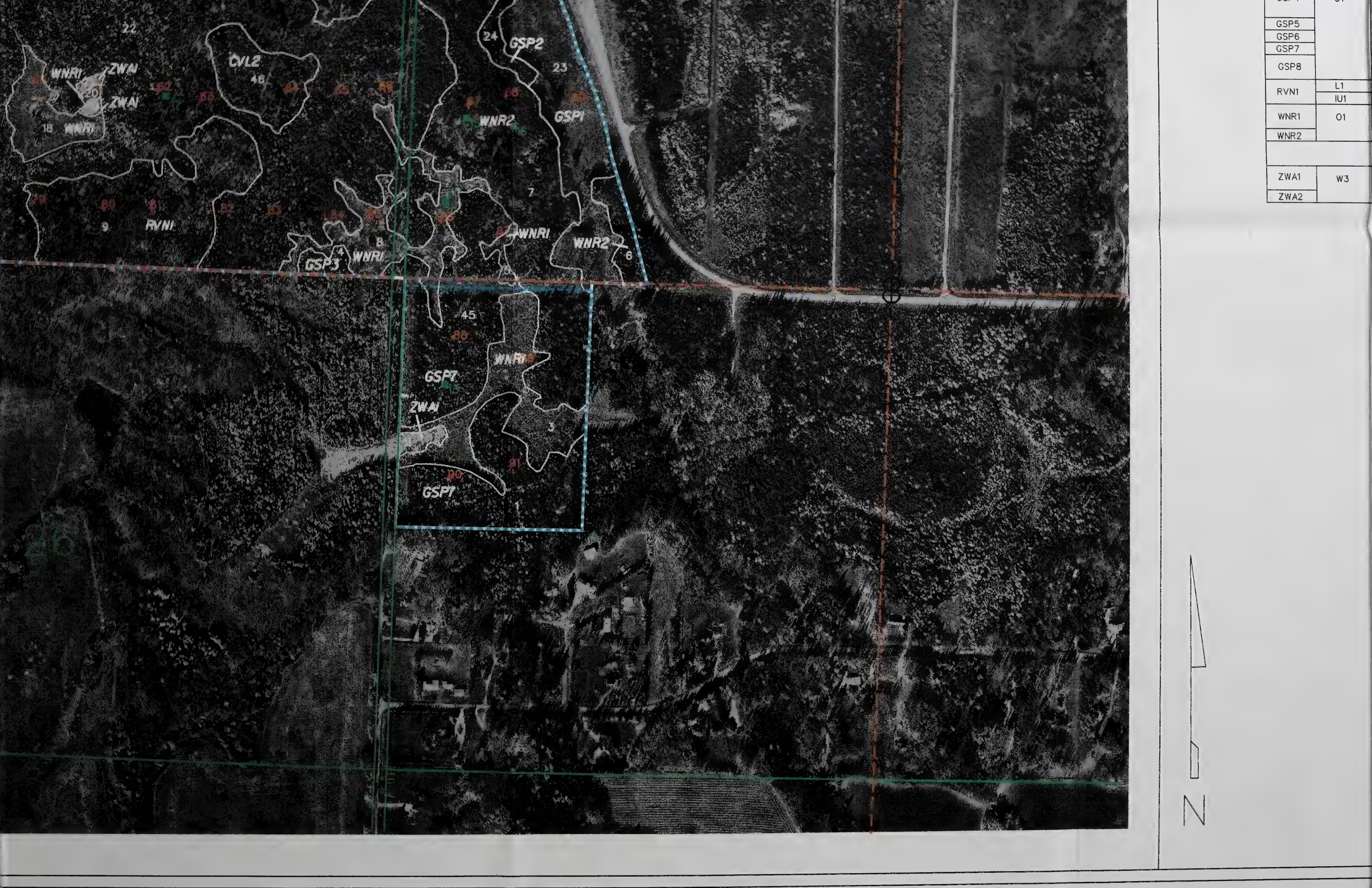




\begin{tabular}{|c|c|c|c|c|c|}
\hline GSP4 & \multirow[t]{5}{*}{01} & \multirow[t]{4}{*}{ Fen peot } & carbonated Terric Mesic Humisols & \multirow{2}{*}{$\begin{array}{c}\text { Fibric Mesisols and carbonated Humic } \\
\text { Mesisols } \\
\text { carbonated Typic Mesisols }\end{array}$} & \multirow{3}{*}{$\frac{31,35}{\frac{13.38}{37}}$} \\
\hline GSP5 & & & carbonoted Terric Humisols & & \\
\hline GSPE & & & carbonated Terric Humic Mesisols & carbonated Typic Mesisols & \\
\hline GSP7 & & & Typic Humisols & Typic Mesisols & 1,45 \\
\hline GSP8 & & Forest peat & carbonated Typic Mesisols & $\begin{array}{l}\text { Limnic Mesisols and carbonated } \\
\text { Mesic Humisols }\end{array}$ & 15,39 \\
\hline RVN1 & $\frac{L 1}{\text { IU1 }}$ & Glaciolacustrine & corbonated peaty Orthic Humic Gleysols & carbonated Terric Mesisols & $\begin{array}{c}26.27 \\
9\end{array}$ \\
\hline WNR1 & \multirow[t]{2}{*}{01} & \multirow[t]{2}{*}{ Marl } & carbonated Rego Gleysols & Woter & $\begin{array}{l}3,5,8,11,18 \\
20,28,33\end{array}$ \\
\hline WNR2 & & & carbonated Rego Gleysols & carbonated Terric Mesisols & 6,7 \\
\hline \multicolumn{5}{|c|}{ Standing Woter } & \\
\hline ZWA1 & \multirow[t]{2}{*}{ w3 } & \multirow[t]{2}{*}{ Woter } & Standing water & & $\begin{array}{l}2,10,17,19,21, \\
29,30,32,34\end{array}$ \\
\hline ZWA2 & & & Standing water & carbonated Terric Mesisols & 42 \\
\hline
\end{tabular}

\section{Map Features}

Soils Polygon Line

Study Area Boundary

- - - Wagner Natural Area Boundary

Alberto Township System Section Lines

- Alberta Township System Quarter Section LInes

Highway

\section{Polygon Number}

72. Reconnaissance Sample Site

G Detailed Sample Site

\begin{tabular}{|c|c|c|c|c|c|}
\hline Meters & 100 & 200 & 300 & 400 & 500 \\
\hline
\end{tabular}


A GALIBOR

A AMELALN

A ANDRPOL.

A ASTEBOR

A CAMPSTE

A CAREAQU

A CAREAUR

A CARELIM

A CARELIV

A CAREPRA

A CAREVIR

A CATONIG

A DREPREV

A DROSANG

A ERIOPOL

A GALILAB

A JUNCBAL

A LILIPHI

A MEESTRI

A MUHLGLO

A PARNPAL

A PEDIGRO

A PINGVUL

A SALIATH

A SALICAN

A SCIRACU

A SCIRPUN

A SCORSCO

A SENEPAP

A TOEIGLU

A TRIGMAR

A TRIGPAL

A UTRIINT

A VIOLNEP

A BRYUPSE

A CAREINT

A CAREGYN

A DICRUND

A ERAGVES

A HABEHYP

A HABEOBT

A SPHAWAR

A CLADCRI

A OXYCMIC

A SPHACAP

A GALITRE

A SALIPLA

A SMILSTE

A TYPHLAT

A LINNBOR

A VIBUEDU

B SALIMAC

B CALACAN

B CORNSTO

B RIBEAME

B SALIBEB

B EPILPAI

B GLYCSTR

B ADOXMOS

B ASTEPUN

B BRACMIL

B BRACTUR

B BROMCII

B CALTPAI

B CAREATH

B CAREUTR

B CICUMAC

B CINALAT

B DREPADU

B DREPVER

B GALETET

B GEUMALE

B HERALAN

B IMPACAP

B LEMNMIN

B MENTARV

B PETASAG

B PHALARU

B RIBEHUD

B RIBEOXY

B RUMEOCC

B SALIDIS

B SALIPET

B SALIPSE

B SALISPP

B SCUTGAI

B SONCULI

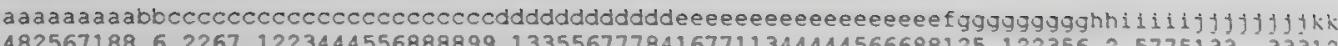
$48256718862267 \quad 1223444556888899 \quad 1335567778416771134444456668812512235625775133 \quad 33312$ 197605456617586483699029575347801581889226724738956035678047801244190142942310131672952303

$11-111111-1-\cdots-0-111$

$11-11-11121$

$111--1111-1$

$24555554454-$

$--11-2-1-2-1-3$

$-1-1-112212$

$111-\cdots-22-$

$111--1---5$

$-3-1---2-$

-11111111 -

$23432424-1$

-1----231-

1--.-1--11

$-1-111--22$

$1--0-1-0$

$1-1--12-1-$

-1----1---1

1141122322

$--1-1--11-$

4-31111--

54133454511

$-1----21--2$

$111--1111-$

$1-1--11111$

$2111112114-3---3-$

1-----1111

$11-21-1-1119-1$

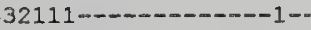

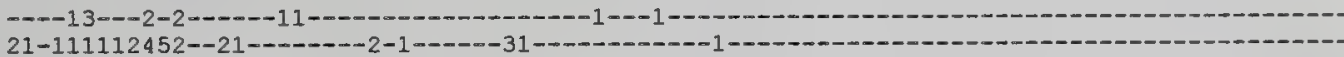

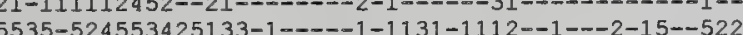

$---1--11151-1--11--1----51-1----1--331--132--$

$-0-1122-10$

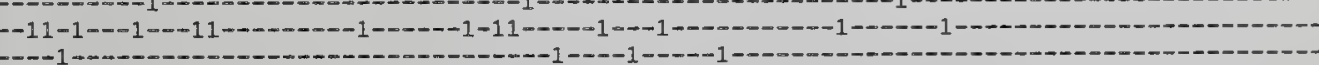

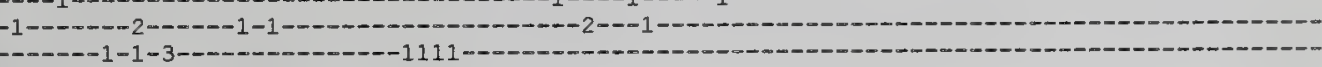

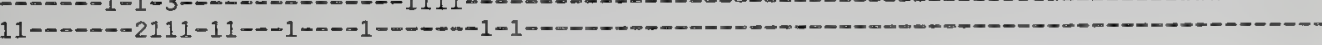

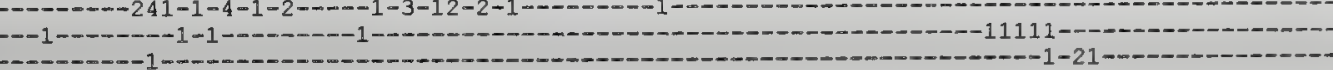

-1--111-11-

$--1-224--2--12111-1-1222-1-3114232-1-12242121122212-112-1-2-42-2-\cdots$ $-1-224--2--12111-1-1222-1-3114232-1-12242121122212-112-1-2-42-2-\cdots-c-1-\cdots$

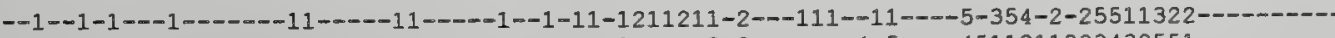

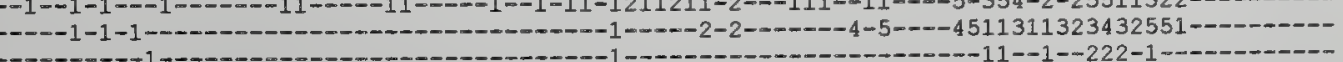

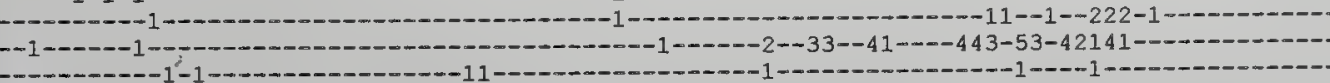

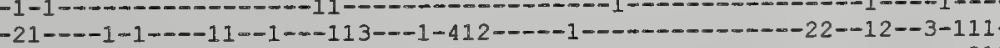

-$$
\begin{aligned}
& \text { MIL } \\
& \text { TUR } \\
& \text { PAL } \\
& \text { ATR } \\
& \text { MAC } \\
& \text { TAD } \\
& \text { TER } \\
& \text { LAR }
\end{aligned}
$$

-11-1-10-0.
2212211-11--1-4545

-

$4-3-1111--15-0-120-10$

-

$223234-1$

$1-1-$

$1-$

$1111-1113--11-1$

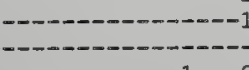

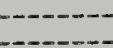

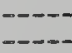

-

$-\infty-11$

$-1-0-21---1-10$

$-1-\cdots-\infty 11$

$1----$

$--$

$322-2$

21122

$1---21-----1-1-\cdots-1--1-0$

$--1$ 
000000111000000000000000000000000000000000011111111111111111110000000001111111000111 


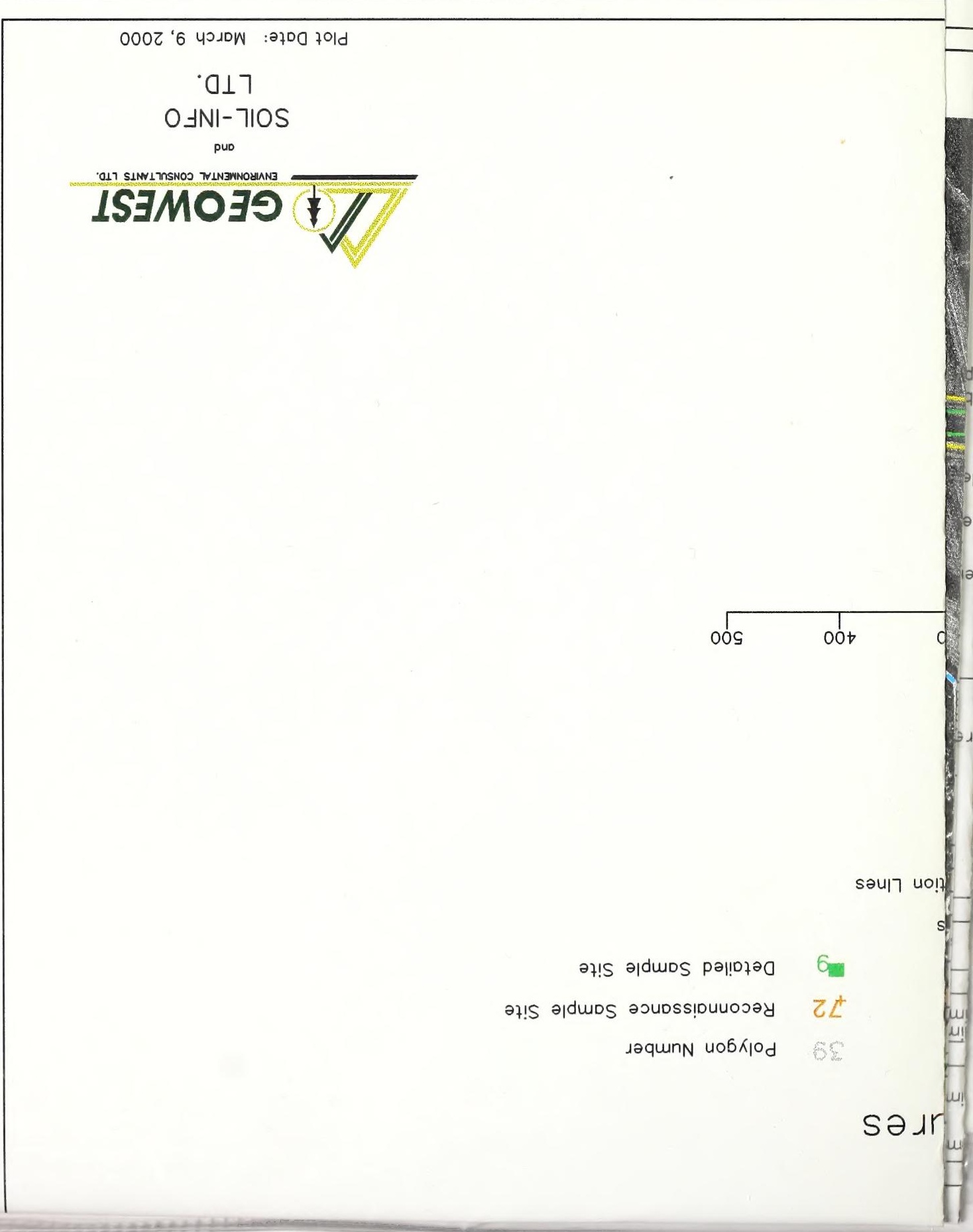



